\title{
Liminal Crossings: \\ Venice Between Time and Space
}

by

Kamila Lukus

A thesis submitted to the Faculty of Graduate and Postdoctoral Affairs in partial fulfillment of the requirements for the degree of

Master of Architecture

Carleton University

Ottawa, Ontario

(C) 2017

Kamila Lukus 
Liminal Crossings:

Venice Between Time and Space 


\begin{abstract}
What lies between the city and the city? What lies between a city's present and its future? The first is a liminal space, the second is a liminal time. Venice has many simultaneously occurring cities within its urban fabric: economic, social and environmental mega forces. Since the 1960's Venice has seen an exodus of its residents, taking with them the memory of an obsolete urban identity. As tourist's flood in by air, train and ship they replace the Venetians equally in numbers: one city is replaced by the other.

This thesis is inspired by China Miéville's novel, The City \& The City, in which Venice's space of "Breach" is the third city that is neither local or tourist, neither permanent or temporary. It is a liminality, a stage unbound between the Venice of the past and the Venice of the future. The cruise ship becomes the site of a liminal Venice, floating between the city's present and its future.
\end{abstract}




\section{Acknowledgment}

I would first like to thank my thesis advisors, Jill Stoner and Ozayr Saloojee. Thank you for the numerous discussions, expertise, edits and inspirations on theory and practice. I am honored to be a student within the wicked city group. Thank you for the opportunity to go on a cruise, without your support and encouragement I would not have experienced this thesis. Thank you both for steering me in the right direction and encouraging me whenever I thought I needed it. To Gabby, for your companionship in the trenches. To all those who have helped me in my thesis, in all its stages, from the ideas on drawings to the editing of the text. I would like to thank my friends, especially Carolyn, who has helped me through the last year, for our countless tea breaks, your support and encouragement. Finally, I must express my profound gratitude to my parents, my sister, Patricia and my aunt Jolanta who have heard countless discussion on Venice supporting me when I was unsure of the direction to take. Thank you all for your support, without you I would have never imagined myself here at this point now. 


\section{Table of Contents}

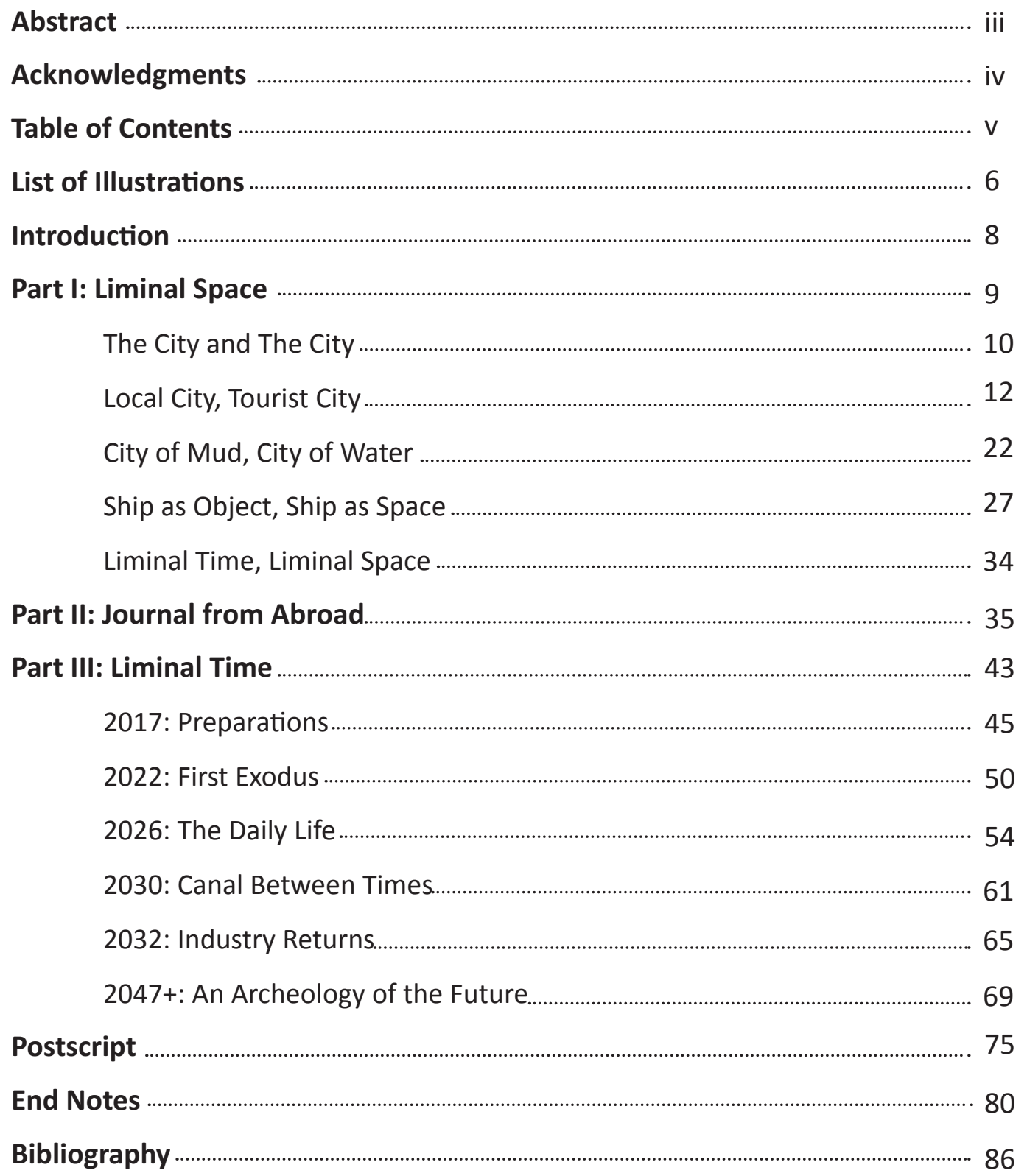




\section{List of Illustrations}

All illustrations drawn by Kamila Lukus, unless otherwise indicated.

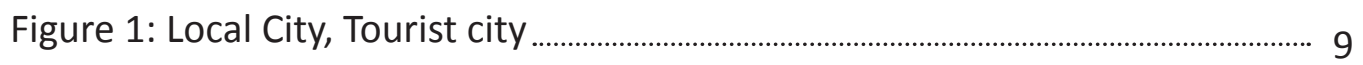

Figure 2: Mapping UI Qoma and Basel ................................................................................... 11

Figure 3: The Local City .............................................................................................................. 13

Figure 4: The Tourist City ............................................................................................................ 13

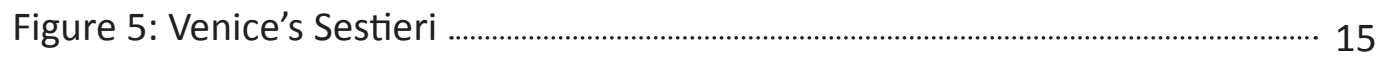

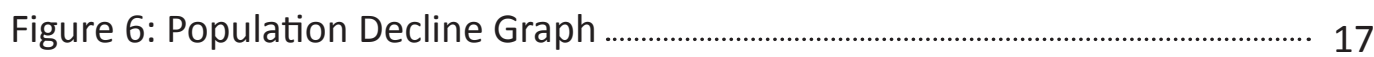

Miller, Kyle. Population of Venice,1540 to 2015. January, 2015.Accessed September, 2016. http://www.navigamus.net/2015/01/declining-population-in-venice.

Figure 7: Micro-Infrastructure of the Local City ..................................................................... 19

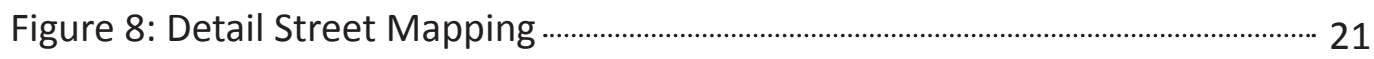

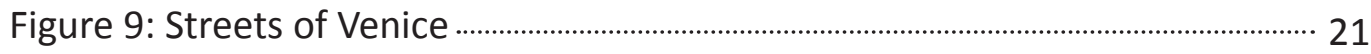

Images taken from Google Streets View

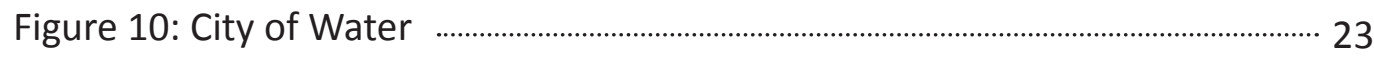

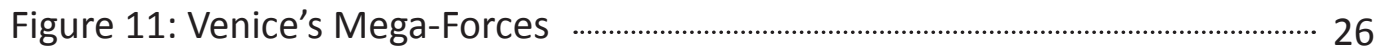

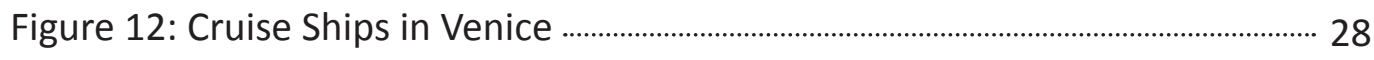

Berengo Gardin, Gianni. Fondazione Forma per laFotografia.http://www. telegraph.co.uk/news/worldnews/europe/italy/11947657/Giant-cruiseships-crushing-the-life-out-of-Venice.html.

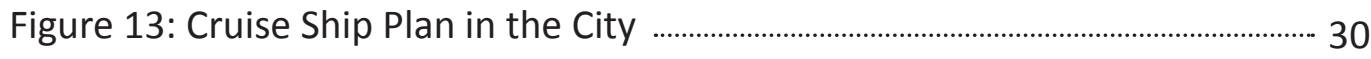

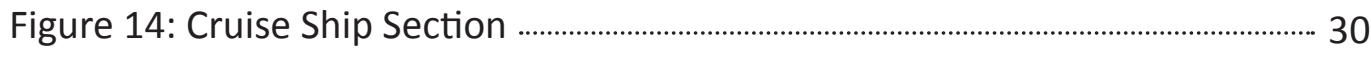

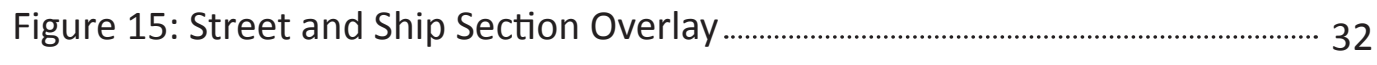

Figure 16: Mirco-Infastructure of the Ships …………………………………………….... 33

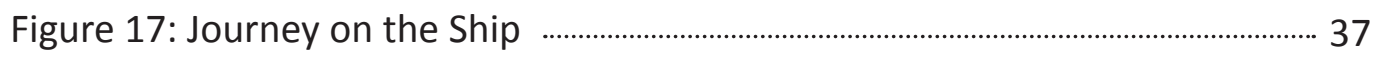

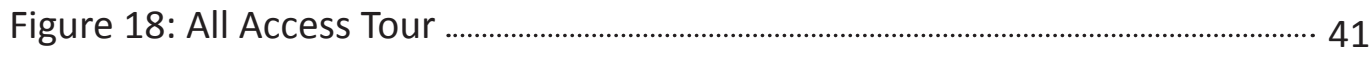

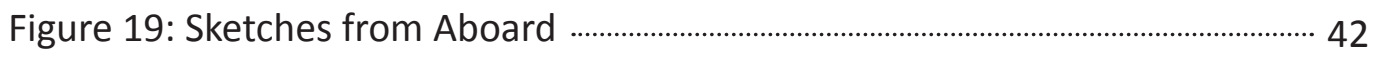




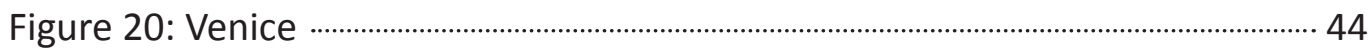

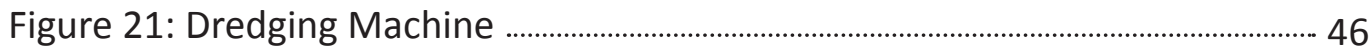

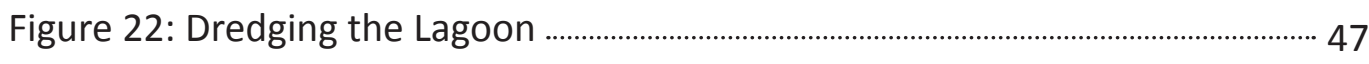

Figure 23: Lifting the Rialto Bridge ................................................................................. 49

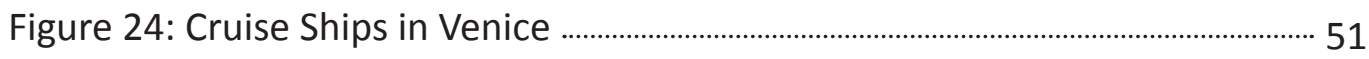

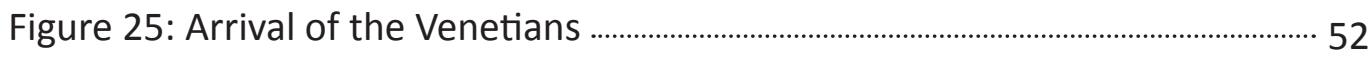

Figure 26: Renaming the Ships .................................................................................. 53

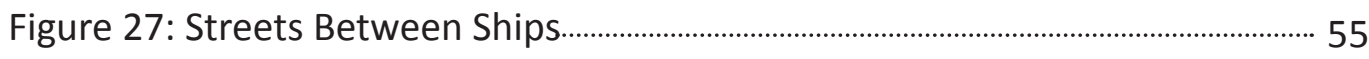

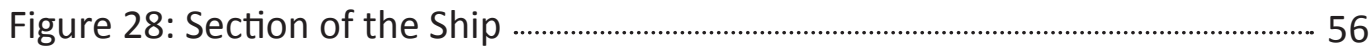

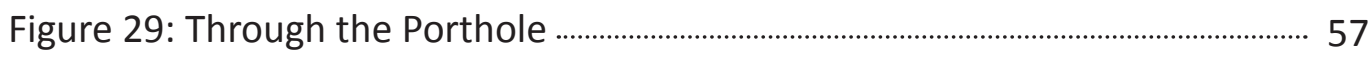

Figure 30: Plan of the Ship …........................................................................... 58

Figure 31: Repairing Venetian Foundations …............................................................... 60

Figure 32: Ship as Dam ..................................................................................6

Figure 33: Vessels in the Grand Canal ...................................................................63

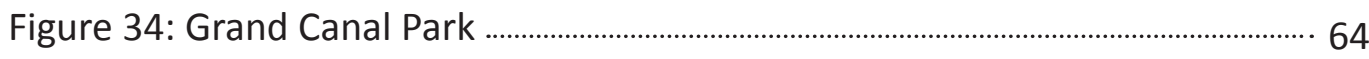

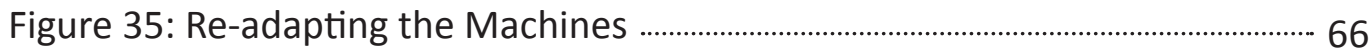

Figure 36: Glassblowing in the Hull ................................................................................67 67

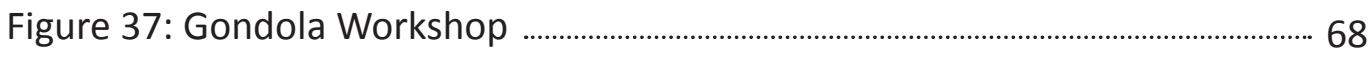

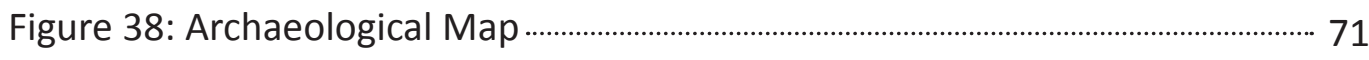

Figure 39: San Michele Cemetery …….............................................................................. 72

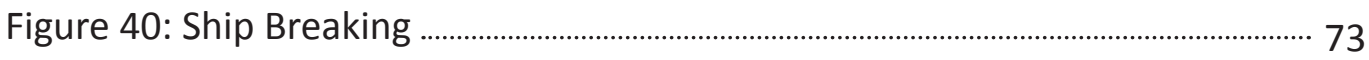

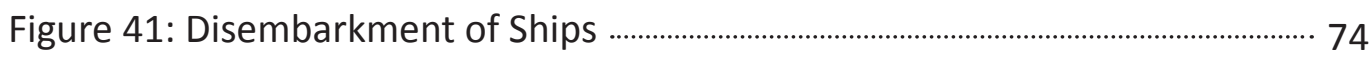

Figure 42: Connecting Venice ....................................................................... 77

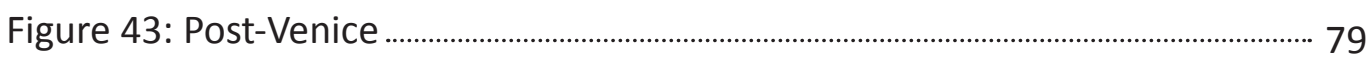




\section{Introduction}

This narrative tells the fantasy of a Venice that is neither the past nor future but a moment, a ripple in the history of the city, a transition of its people. It is a narrative divided into three sections: first is space, the second is my own journey on a cruise ship, the third time. In part one, the city in its present form reveals a geography split into local and tourist zones. In part two, the space of the cruise ship is understood through the journal from my own journey. In part three, a collection of urban maps trace Venice's future, during which the cruise ship is transformed from a buoyant container into a mechanism of infrastructure, neighbourhood, and industry. The wicked condition that is Venice generates this temporal fiction and gives substance to many forms of liminal crossings. 


\section{Liminal Space}

Part I

Liminal space investigates the structure of Venice today, a pair of cities occupying the same space. (Figure 1) It focuses on the city's social, ecological, economical forces in the identification of a third city. In its exploration, it sets the stage for a speculation on the future of Venice.

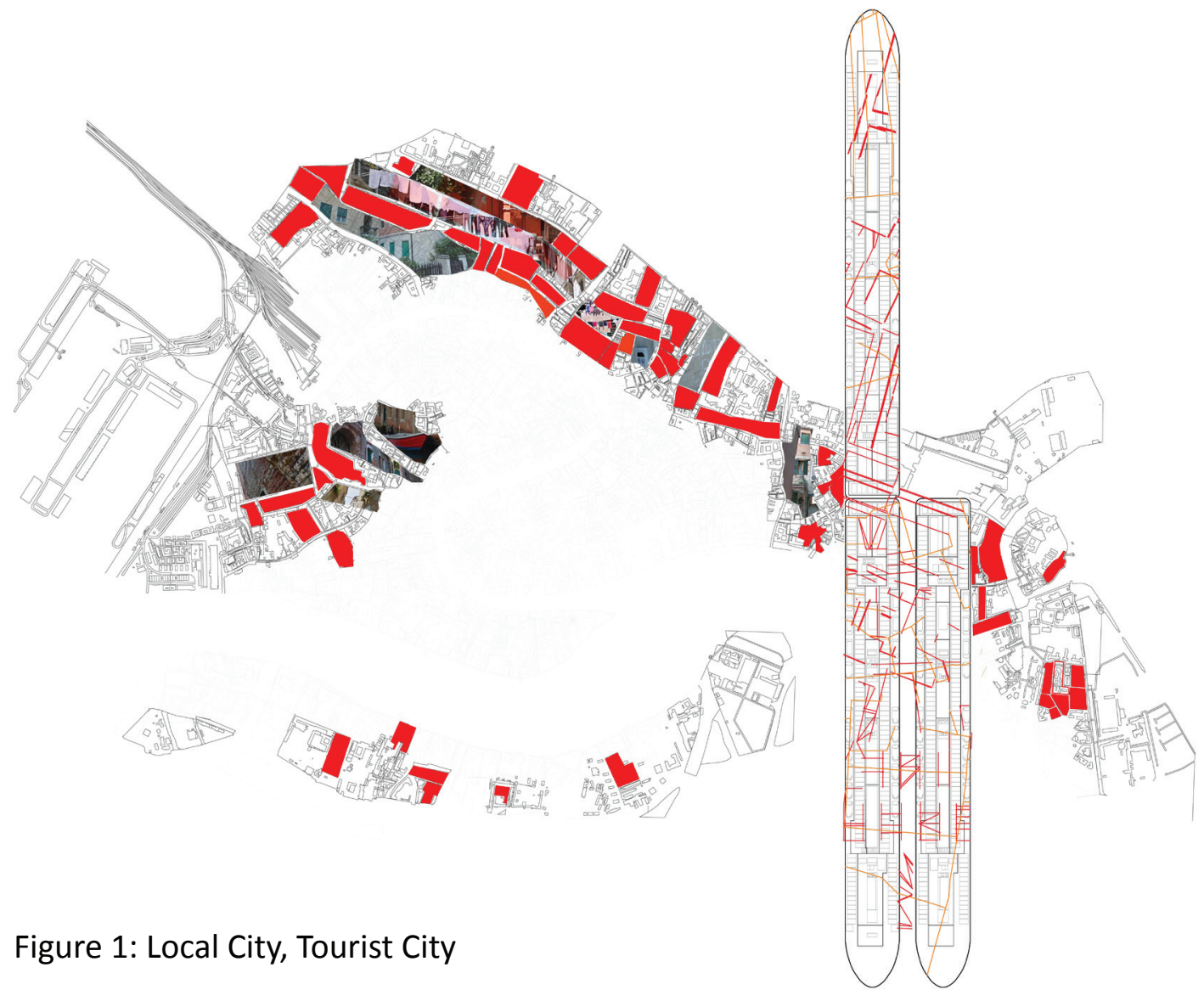




\section{The City and The City}

China Miéville's novel, The City \& The City explores the invisible boundaries between two cities, Baszel and UI Qoma, as they occupy the same geographical space. (Figure 2) The narrative uncovers a mystery that occurs somewhere in the liminal border between the two cities. A woman at the UI Qoma's ancient dig site is murdered, and clues point to her fascination with a hypothetical third city of Orciny. Instead of finding the new city, the protagonist detective named Borlu uncovers the space of Breach, a space unbound by the limits and laws of each government.

Basel and UI Qoma, separated by language, clothing style, government and architecture have only a sensory boundary; the citizens of one city learn to "unsee" the citizens of the other. Yet moments in the streets of each city overlap, or "crosshatch". The act of "seeing" or crossing into the other city, results in a condition called "Breach". As Borlu comes into Breach, he understands that he has entered a liminal space. He describes how he walked the cities, in the Breach," I was learning ... how to walk between them, first in one and then the other, or in either". ${ }^{1}$ He becomes a part of the third city, a city in between the two. $^{2}$

Venice is also two cities- a city of tourists and a city of locals; yet it has not yet discovered its liminal space, the third city between the two. 


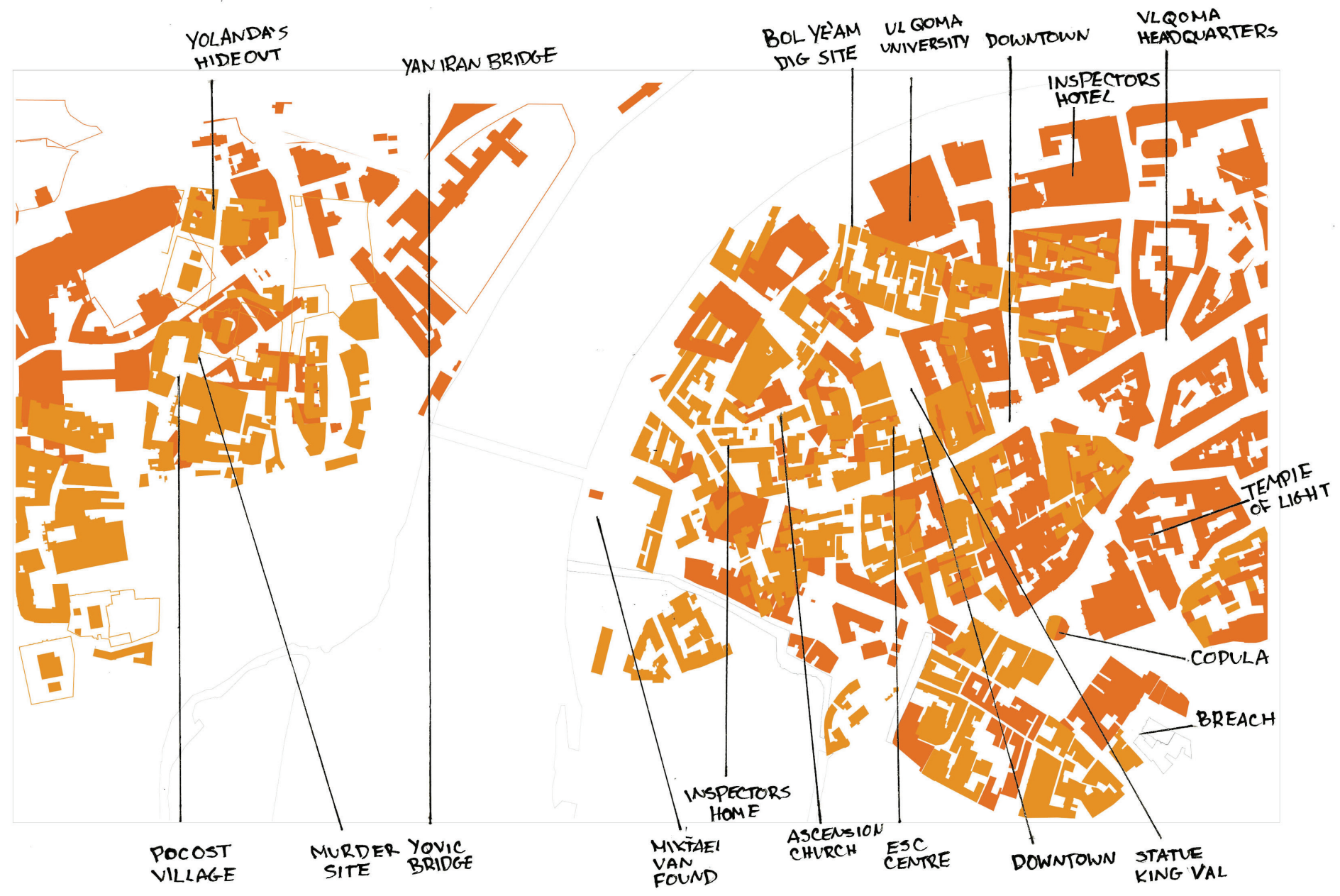

Figure 2: Mapping Baszel and UI Qoma

Mapping the events of the novel in the identification of the UI Qoma "crosshatch" spaces of the two cities in one space to locate the Breach. 


\section{Local City, Tourist City}

Clothing rustles against clothing, criss-crossing the narrow streets in the hidden neighborhoods of Venice. Residents walk the quiet back alleys, peering into their neighbour's small front gardens. ${ }^{3}$ In each of the six sestieri, church bells chime the arrival of the working day. (Figure 3) Small motor boats spew noise through the narrow canals, signaling a city coming awake. Further along the canals becomes wider, a business made up of sounds and stimuli like flashings of cameras and chatter in multiple languages. Tourists stay in their herds, rustling their maps in the search of their city, following the signs to Piazza San Marco, to the Rialto Bridge and the Accademia. (Figure 4) These local and tourist worlds keep each to their own space, unseeing each other, hardly ever crosshatching. 


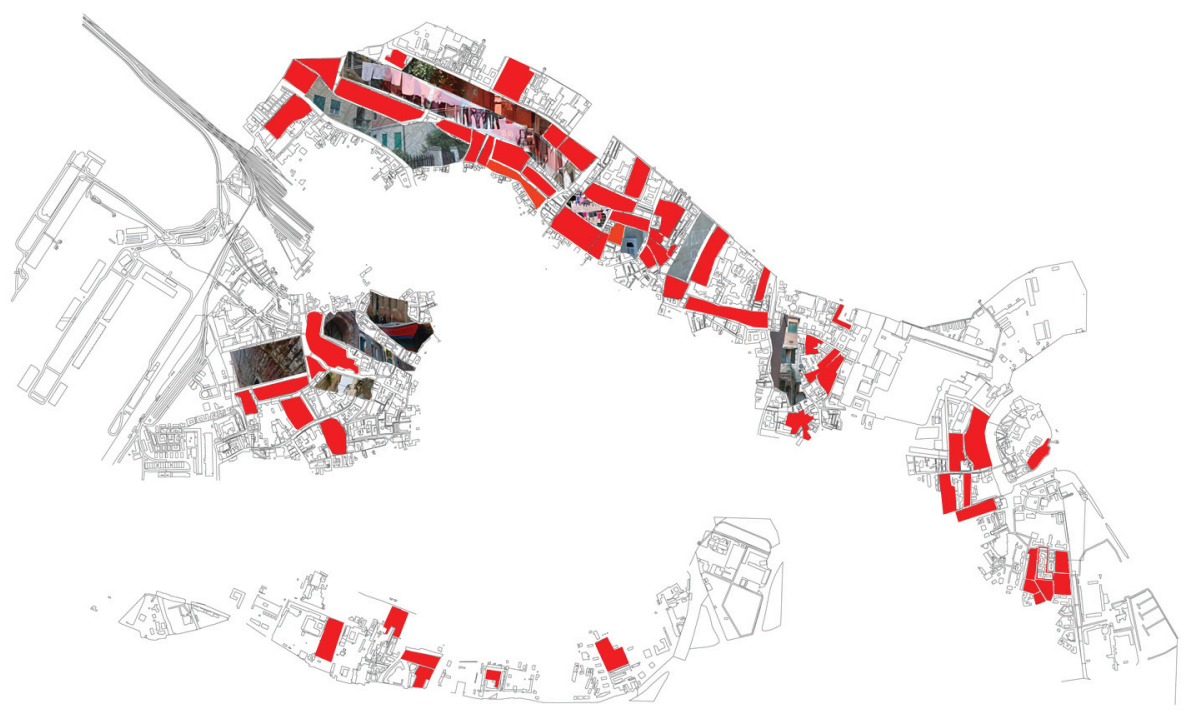

Figure 3: The Local City

The local city is defined by the red blocking of neighbourhoods, through the subtraction of the tourist monuments within a city map. Snapshots of streets are illustrated in the neighbourhoods.

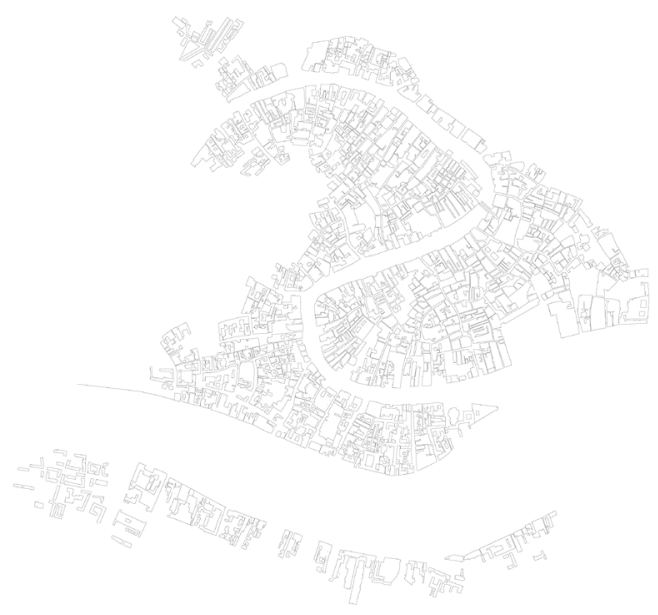

Figure 4: The Tourist City

The city of the tourists has taken over the main central area of the islands, the place that had once belonged to the local Venetians. 
The six sestieri, or neighborhoods, are named; Cannaregio, Castello, Dorsoduro, San Marco, Santa Croce and San Polo. (Figure 5) Each is distinguishable by its unique identity; each has its own political representative and house numbering system. ${ }^{4}$ The neighbourhood of San Marco is the center of the medieval city, with St. Mark's square, Dodge Palace, the Basilica, libraries and prisons. Its streets are busy with crowds of tourists filling into the square looking for carnival masks and venetian glass beads. Cannaregio, between the train station and the Rialto bridge, is an area comprised of both residential and tourist population. This neighbourhood is home to the "old" and "new" Venetian ghettos, with clothing lines suspended between the canals, synagogues, fountains and more contemporary artists' studios and shops. The outer neighbourhood of Castello is a workers' housing area that was linked to the Arsenale, the site of Venice's shipbuilding industry. Dorsoduro is home to the ports, gallery and customs area. San Croce and San Polo, deep in the former area of salt marshes, have been demolished and rebuilt from the 1800's monasteries into residential housing complexes with integrated workshops. ${ }^{5}$ Within these six sestieri, we find moments of local culture and identity. 


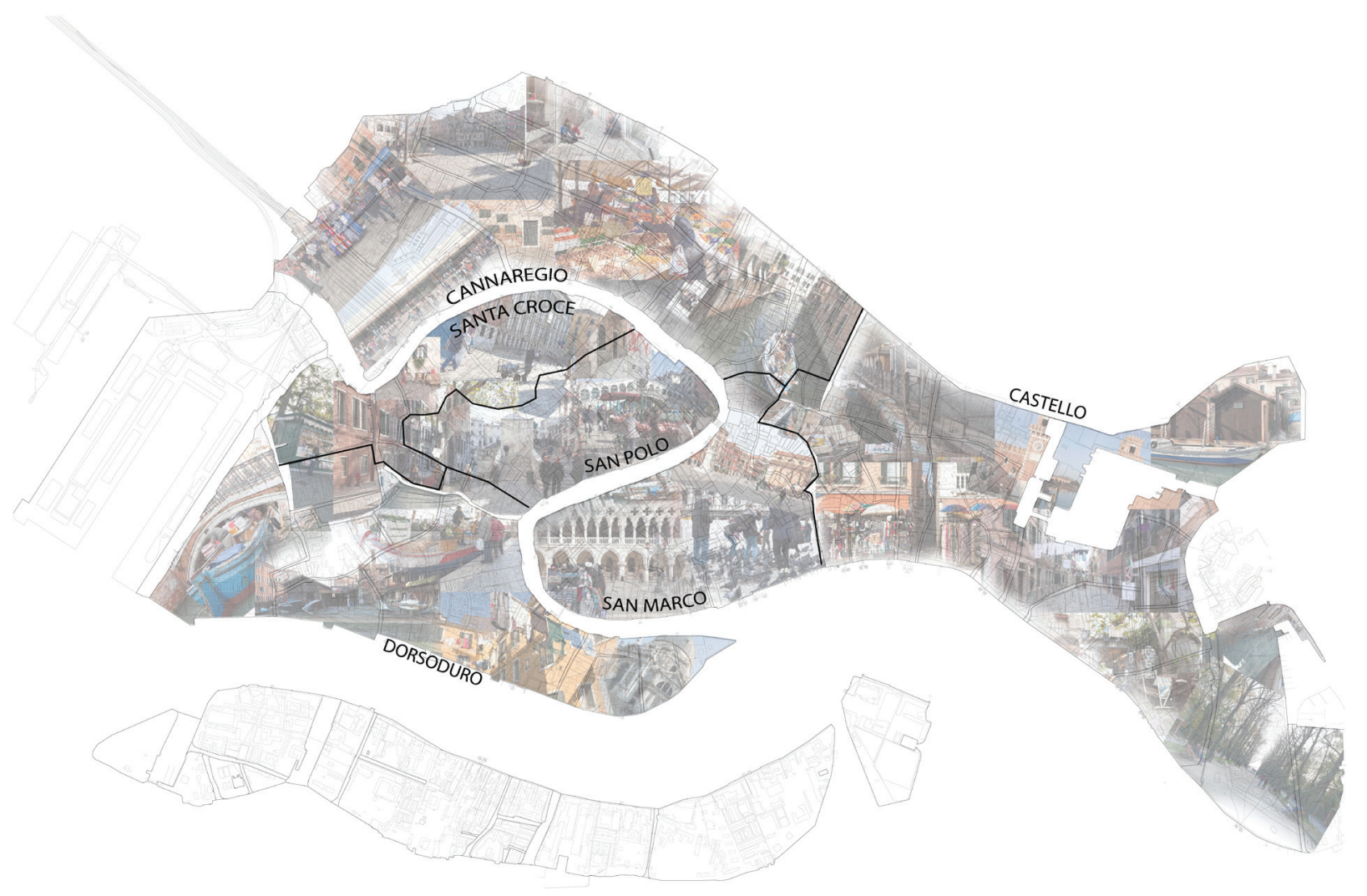

Figure 5: Venice's Sestieri

Six neighbourhoods each identified with their own numbering system and local culture visible in the collage of photographs. 
Venice has been subjected to an exodus of its people, as social and environmental mega-forces place strain on the city and its citizens. From the early 1900's when 120,000 Venetians lived in Venice, the city's population has been steadily decreasing as social and environmental factors have propelled its citizens to move to the mainland. At a rate of 2500 a year, Venetians who have been priced out of the city are leaving in search of stability and affordability (Figure 6). ${ }^{6}$ In their place, investors and foreigners with access to wealth have bought the ancient houses, renovating and turning them into secondary vacation homes or boutique hotels. For the some 50,000 who remain, there is a lack of employment opportunities outside the tourist sector, low birthrate and buildings ill-suited to adaption for an aging population. ${ }^{7}$ These residents now live in the outer sestiere of Cannaregio, Castello and Dorsoduro. Within these pockets of the local city, each street is a fragment into what no tourist can see.

The city of the tourists has taken over the main central area of the islands, the place that had once belonged to vibrant trade. This was a city rooted in industrialization, from the first guilds of specialized crafts to the industrial mills of the 19th century. ${ }^{8}$ These architectural spaces have all but disappeared. Even on the islands of Murano and Burano, for centuries known for their handcrafts, the industries have regressed to mass production. 


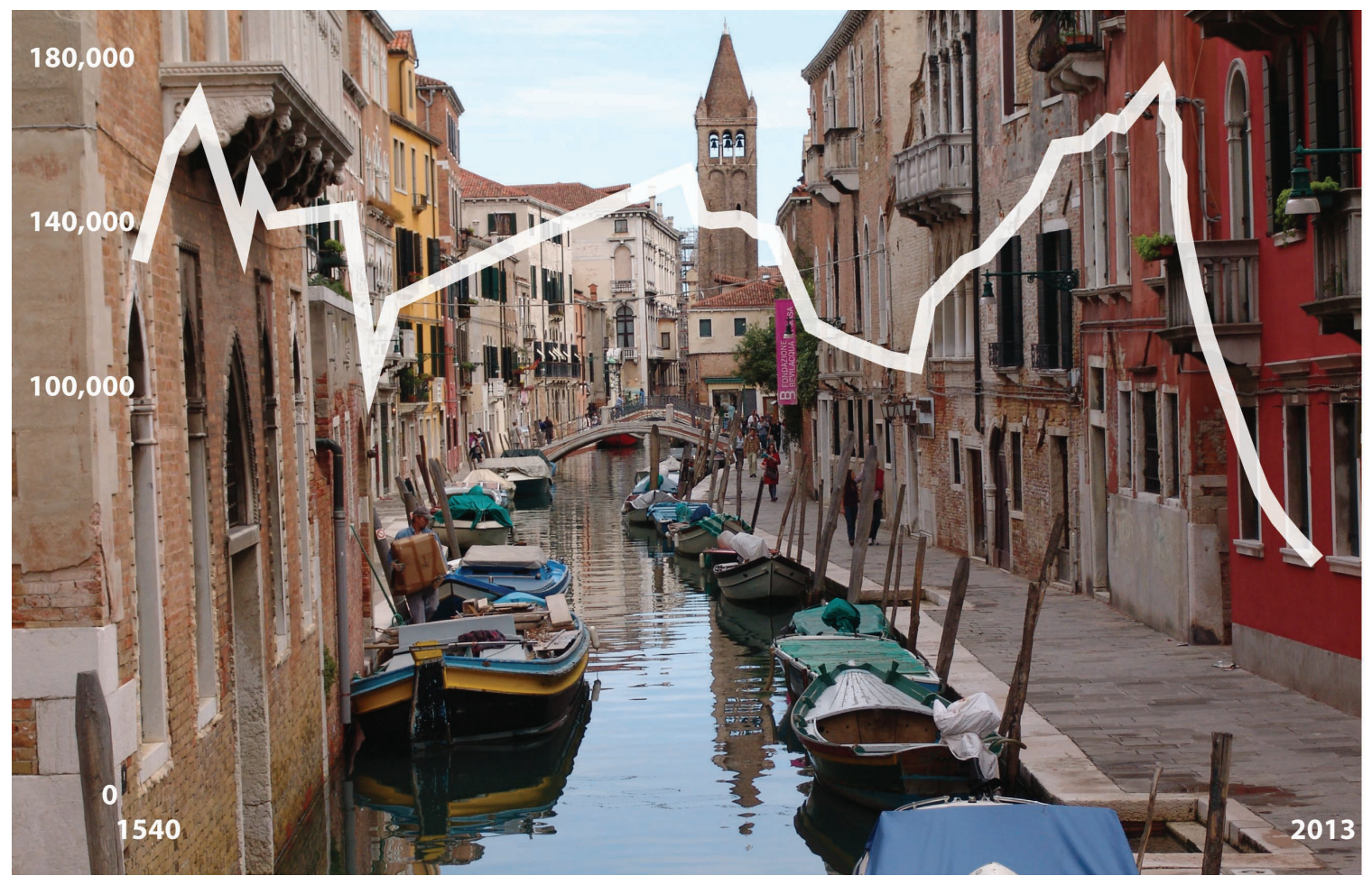

Figure 6: Population Decline Graph

The population demographics began a drastic decline with the flood of 1966 and continues to fall as the mega forces act upon the local city. 
From the first pilgrims who traveled to Venice to find religious connection in its art and architecture, to the hoards of tourists who today arrive in the search for the real "Venice", the city has always attracted foreigners. ${ }^{9}$ Tourists are now almost the only source of income. Piazza San Marco is densely crowded, body against body, each foreigner following signs along the designated paths to the basilica. The tourists outnumber the locals by a ratio of 140:1. ${ }^{10}$ The money the tourists bring in barely pays for the city services such as garbage removal and minimal repairs to the fragile walls of the buildings along the canal. (For example, on October 13,2016 , the city brought in 500,000 euros in tourism taxes; the bill for city services on that day was 400,000 euros. ${ }^{11}$ ) Outside of the tourist economy, the local retail, workshop masters are unable to find apprentices; sixteen hundred local craft shops have closed since the 1980 s. $^{12}$ Year by year, banks, schools and shops are closing as the city of 55,000 tries to accommodate for the "other" city of 25 million. ${ }^{13}$

Hidden in the streets at the edge of the city, visible on Google Maps, are graffiti marks on the edges of the walls, colourful hanging clothing over the canals, and balconies of tiny but healthy gardens. (Figure 7) This daily life, with its micro-infrastructure, is in the shadows of the tourist city. (Figure 8 and Figure 9) The two cities, each unseeing the other, co-exist in an uneasy partnership, as the physical fabric of the city sinks slowly into the lagoon. 

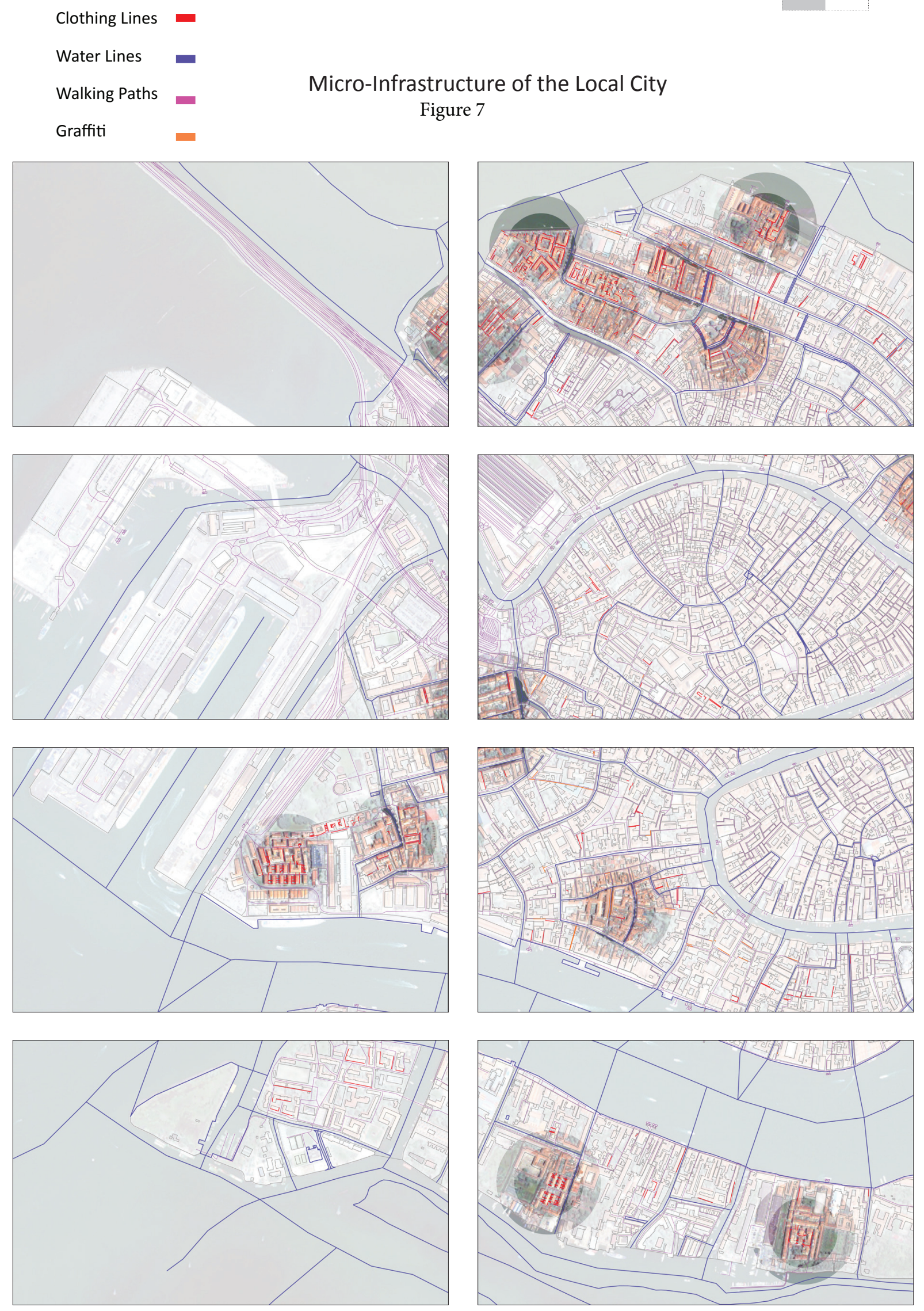

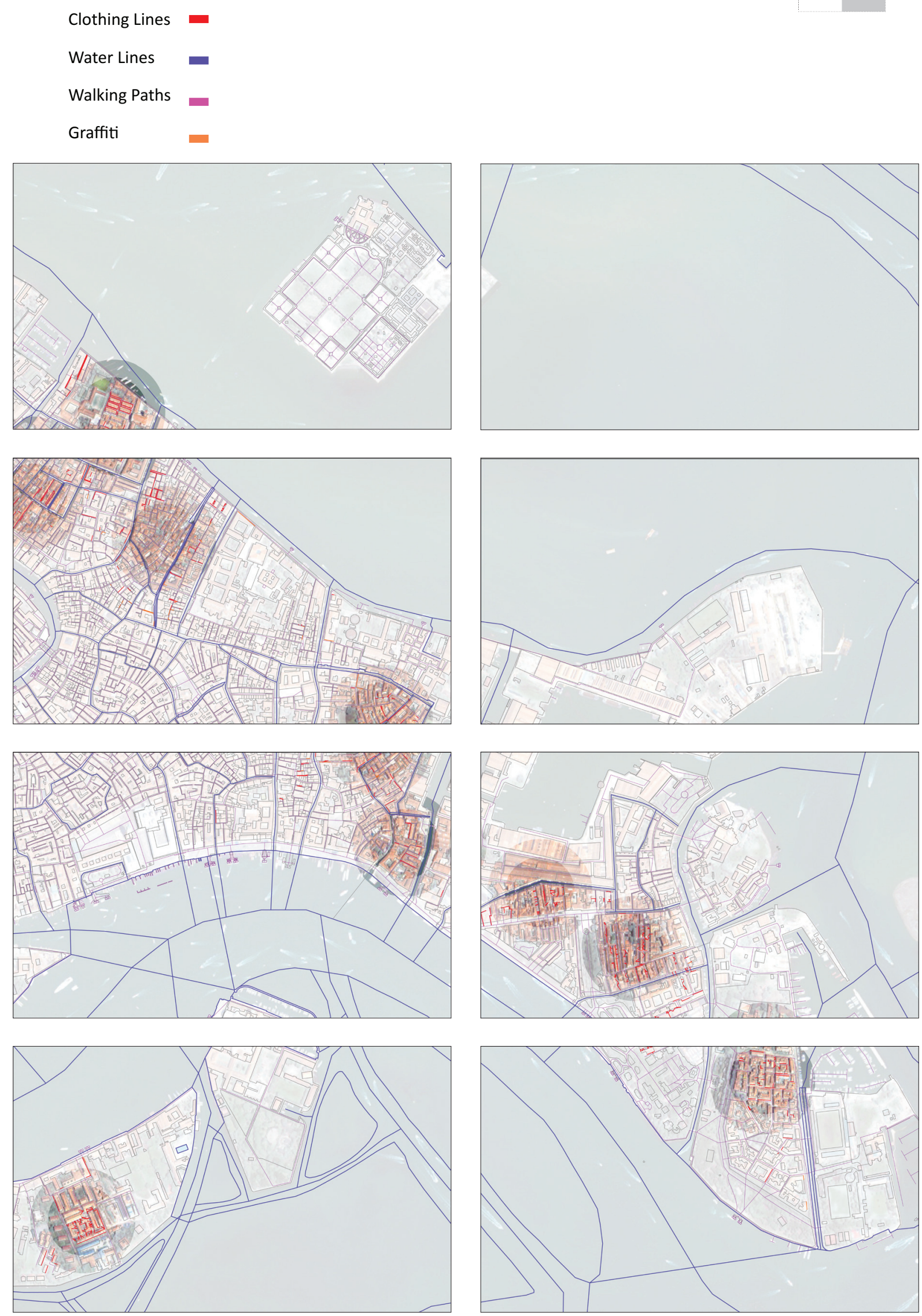


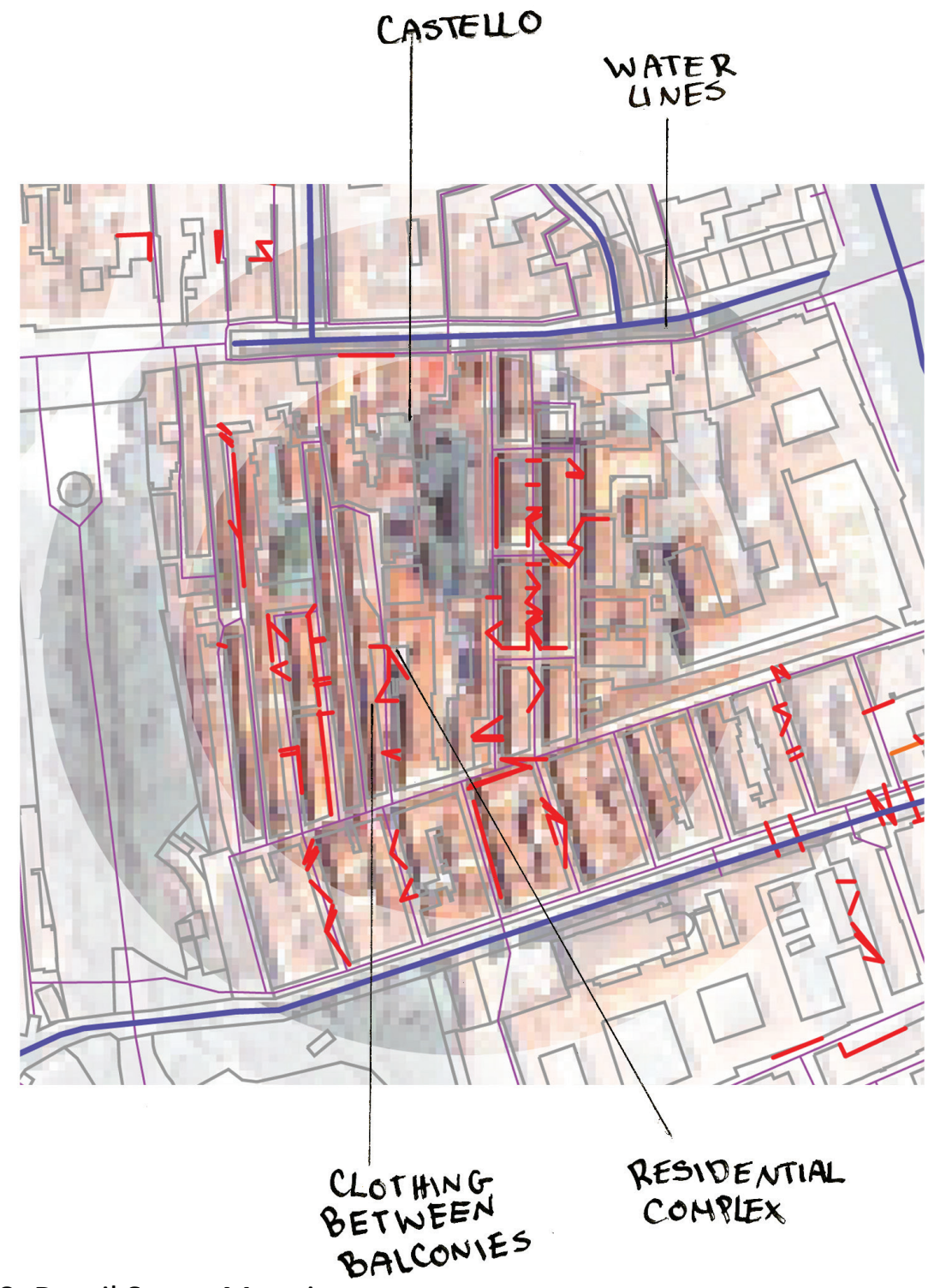

Figure 8: Detail Street Mapping

Through Google map street view the local city is identified with the hanging laundry, graffiti on the walls and gardens on balconies.
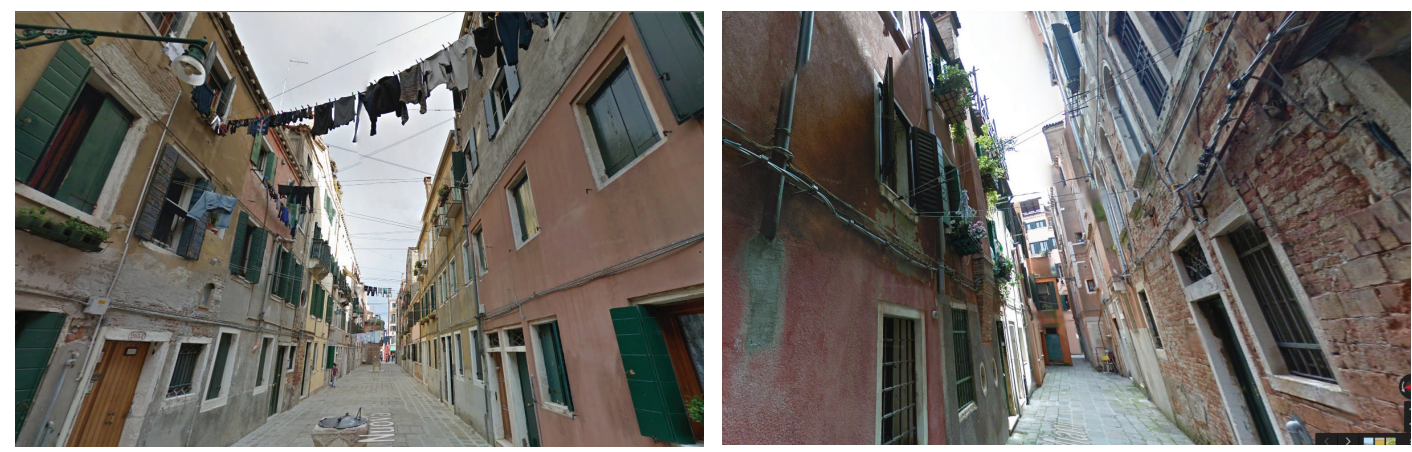

Figure 9: Streets of Venice

Venetian streets through Google maps in identifying the local city. 


\section{City of Mud, City of Water}

Venice is a constructed landscape entirely built upon mud and clay always changing and unstable. ${ }^{14}$ The wetlands are composed of a network of ecosystems, salt and sediment banks. Once, this seemed an ideal landscape for those who settled there. In reality, it is a set of 118 islands, entirely constructed by engineers who dredged the lagoon, built retaining walls, and invented the mechanisms to keep the waters separate from the land. ${ }^{15}$ The city is constructed on pilings driven deep into the swamp. Its most unique feature is the series of canals, of varying width and depth. The Canal Della Giudecca, with depths of 15 meters, allows massive cruise ships to move through the lagoon past the Piazza San Marco into the port of Venezia Terminal Passeggeri.

In the marshy swamp lands of Venice, the city continues to be a stage for the simultaneously occurring forces that act upon it. The two cities of land and water appear and disappear over the year as the water hides and reveals each. With each cycle of Aqua Alta (high water), the sea rises and rushes into the streets and Piazza San Marco, flooding beneath the raised wooden platforms that allow the city to still function. It was the flood of 1966, rising over 1.94 meters, flooding homes, churches and canals that marked the departure of the local Venetians. The destruction left in its path over 5,000 locals without their homes and more than six billion euros in damages. ${ }^{16}$ 


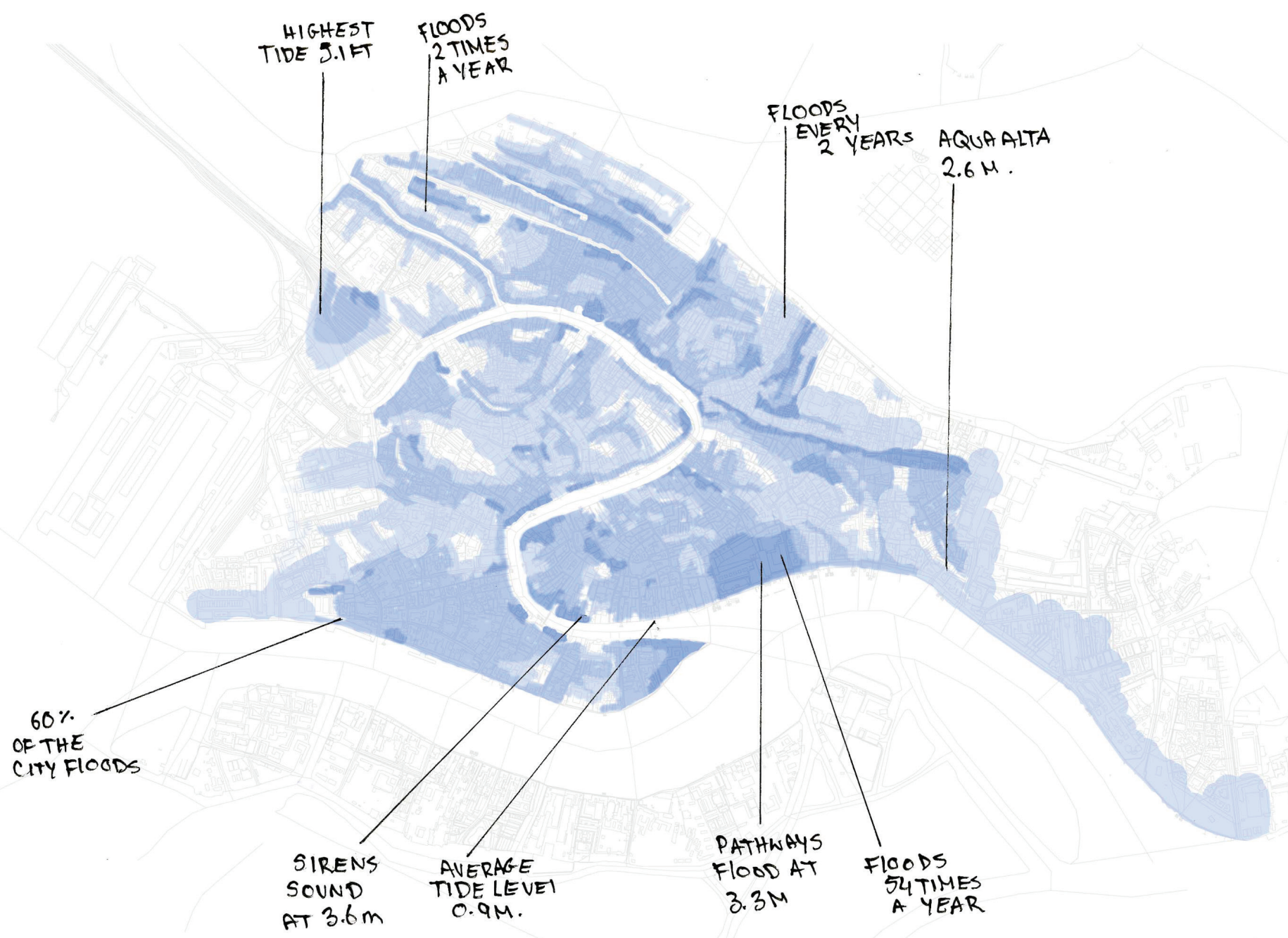

Figure 10: City of Water

The water flooding the city with the intensity of blue illustrating the amount of times the city floods. 
Venice is continuing to slowly sink and flood. The extraction of ground water for manufacturing in the early 1900's has caused the building foundations to become unstable. As the ground settles the brick is exposed to corrosive salt. ${ }^{17}$ The increase of boats appearing in the city and the waves they create have caused the protective stone layer to shift exposing the brick bellow, eroding the walls of the buildings. It is also flooding due to the rising water of the Adriatic Sea. The current rate of the city sinking is by about 4 millimeters a year and the water is rising by 2 millimeters. (Figure 10) The prediction is that the land will sink 76 millimeters in the next 20 years. ${ }^{18}$ This mega force of water reveals a new topography of Venice as the two cities of mud and water shift and change with each season. 
The city of water was the way of life, a risk, a profit, and a glory as Venetian history is the sea; it was the source of wealth, a city built on merchant trades. Venetians lived between the worlds of land and sea, as the island of communities became the center of trade for manufacturing luxury goods of glass, soaps and ships. Small communities of fisherman and monasteries developed among the islands, independent of each other except for the common goal of the fight against the sea. Venice has no center of planning but instead, its origin began from hundreds of different points all collectively growing. ${ }^{19}$ Venice has been a society of a collective gathering of foreigners, a place of acceptance in its diversity of religion, language and people. The islands of refuge became the islands of trade, the center of the lagoon in its establishment of a single dominant identity in the trade routes of the east and west. ${ }^{20}$ The identity of Venetians as a city of trade along with their traditions and festivals are directly connected to the rituals of the sea. The city became "married" to the lagoon every year in the Festa Della Sense. A blessed ring was thrown into the lagoon by the Doge of Venice proclaiming their union of the sea to its people. ${ }^{21}$ In the simultaneously occurring cities of Venice, the city is overwhelmed by the pollution of the canals, the overpopulation and crumbling structures. Looming in the distance, cruise ships cast their shadow on the city below. (Figure 11) 


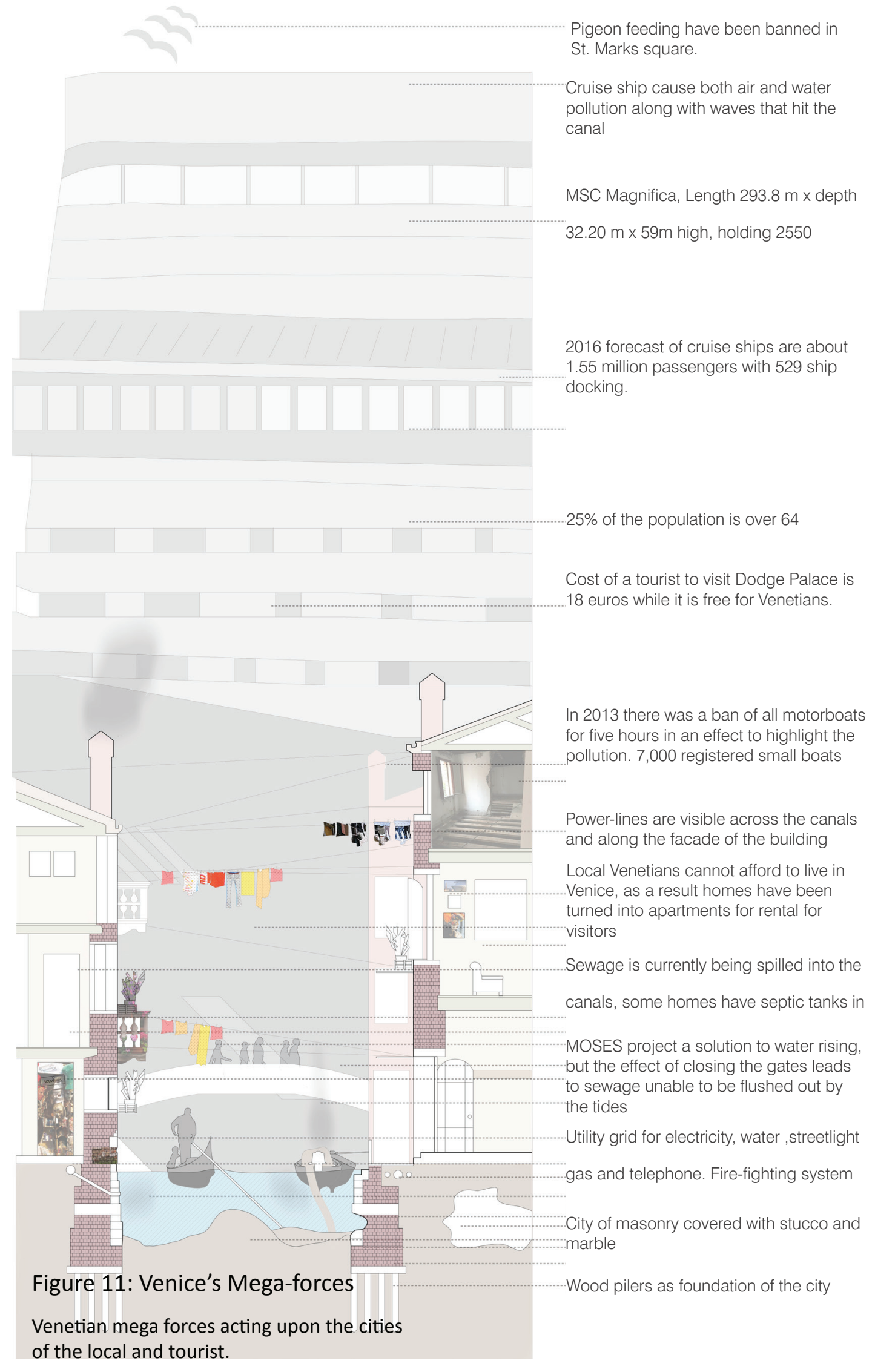




\section{Ship as Object, Ship as Space}

On the streets of Venice, in the crowded square, a giant white sail glides along the edges of the city. People avert their attention from the looming mass above the stone buildings, trying to "unsee" its strange presence. The locals move among the tourists towards their work, school and home as a wall of windows pass by. As the city is continuously and rapidly transforming, the ship moves between the tides of people and landscape from place to place. (Figure 12) It is a temporal object as it docks into the city for a scheduled period, loading and offloading the tourist city and once again returning to its choreograph motion. ${ }^{22}$ 

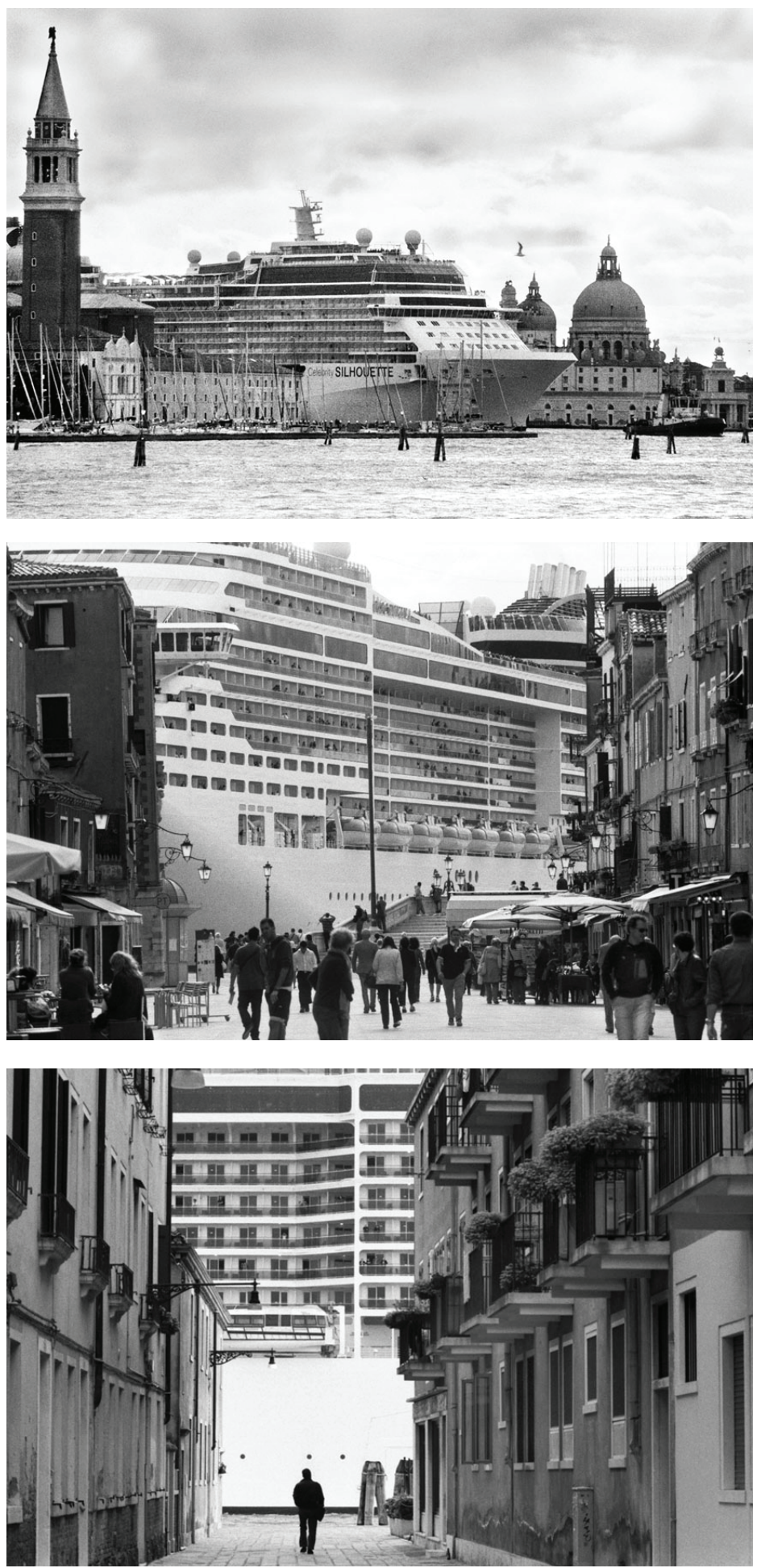

Figure 12: Cruise Ships in Venice

Photographer Berengo Gianni illustrates the relationship between the scale of the city to the scale of the ship. 
The cruise ship is a floating city, a massive buoyant object detached from land and subject to its own time. Within 15 decks its engineering guarantees its containment of all sleeping, hygienic, dining and entertainment needs for thousands of people. Its construction begins in a dry dock, its parts assembled in a warehouse large enough to hold its mass. Robots cut sheets of metal, fusing its joints, lifting them into place. Sections are made, layer by layer the levels grow. In the dry dock the sections are welded together to become a whole. As the framework is completed prefabricated cabin units and public spaces are slid into the structure. ${ }^{23}$ The final height is over 50 meters soaring above the water, overlooking all structures below. The machine stays afloat despite its weight against high tides, scorching heat, and winter storms. The completed machine glides along the Giudecca Canal to the terminal, its engines rowing, smoke spewing and waves hitting against the canal walls.

Inside each ship there is a structured network of passageways ${ }^{24}$ that lead to hundreds of cabins filled with tourists. (Figure 13) Each unit is repeated, $38 \mathrm{msq}$, consisting of a bed, wardrobe, private washroom and a porthole ${ }^{25}$ to the exterior. The ship is a monolithic structure, hiding its secrets deep within its hull. ${ }^{26}$ Here are the location of kitchens, mechanical rooms and, crew quarters below the waterline. On the upper decks are cabins, theaters, fitness facilities and, fancy dining rooms. All spaces are compact and efficient in the design to accommodate as many individuals as possible. (Figure 14) 


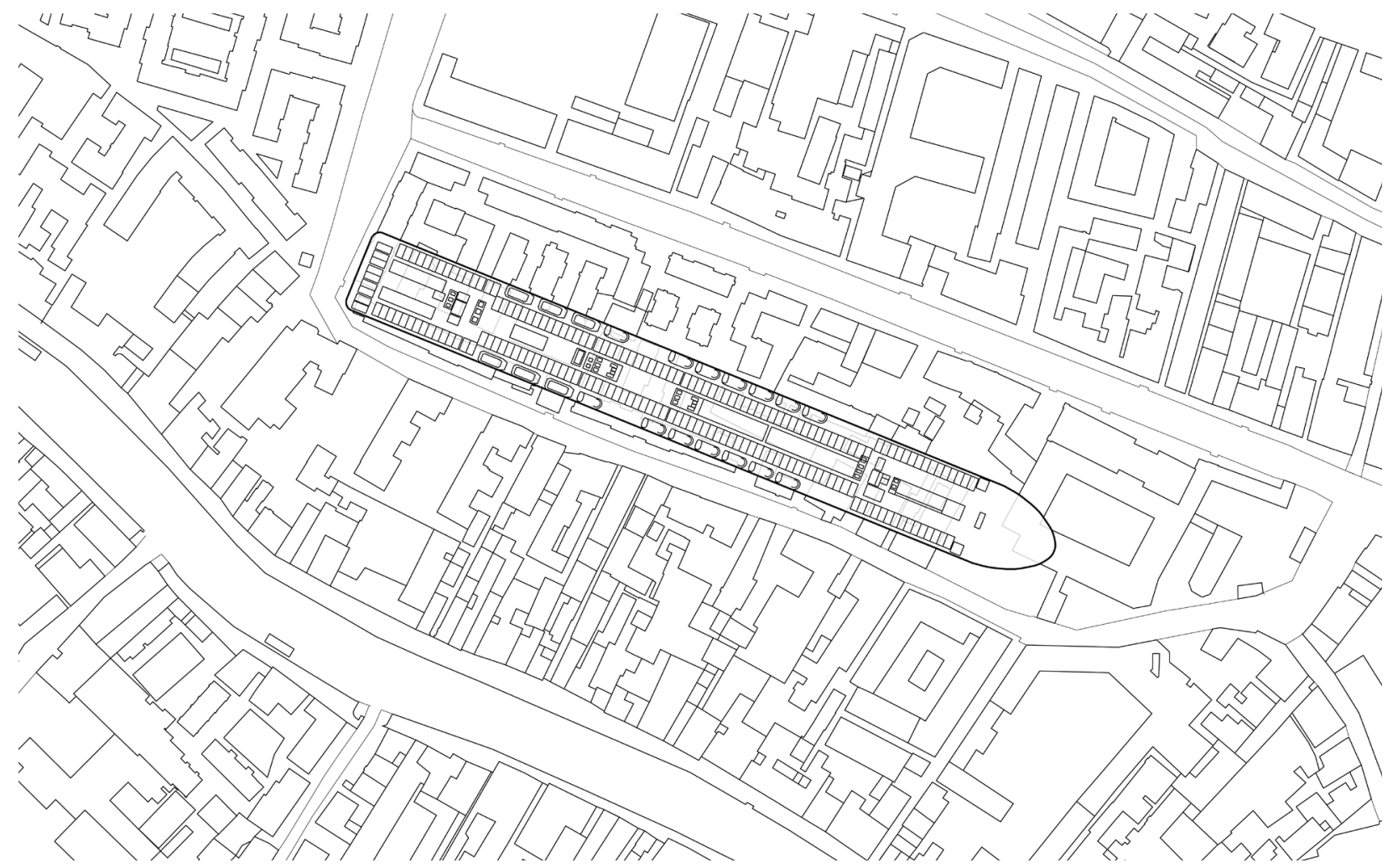

Figure 13: Cruise Ship Plan and Section

Cruise ships placed within the city, the passageways are organized in efficiently to fit as many cabins as possible. In comparison to the maze streets of Venice, the ships passageways are linear and compact in design.

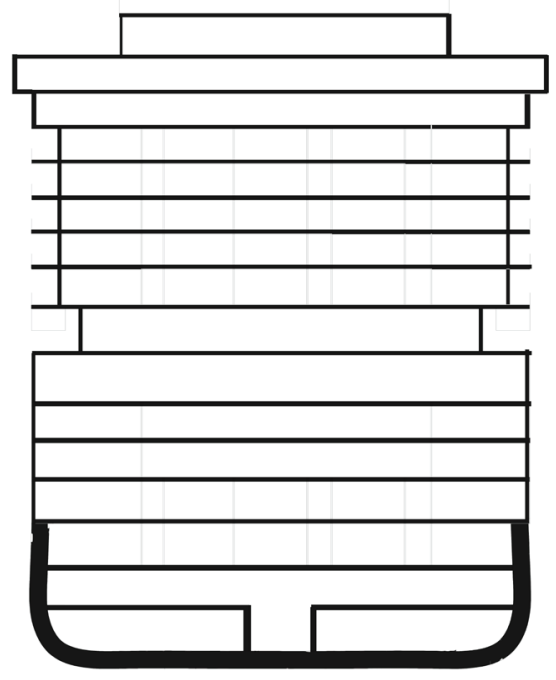

Figure 14: Cruise Ship Section 
As a city historically connected to ships, the vessels of today are the production of the monoculture of Venetian economy. ${ }^{27}$ The white masses moving along the edge of the city recalling the trading ships of the past; yet they are importing people instead of goods. Their affect is a struggle of economy over identity. The cruise ship tourism provides a large contribution to the economy of the city; but in this "success," the Venetians seem to have lost much of their own culture and environment. They protest the white invasions, and at the same time recognize that their survival depends on them.

Over 20 cruise liner companies offer voyages to and from Venice. ${ }^{28}$ On an average day 30,000 cruise passengers disembark from the terminal for a few hours into the city. ${ }^{29}$ In January 2015, the Venetians requested a limit on the tonnage of ships allowed into the city, and are seeking to relocate the ships' path to the terminal. Thus far, cruise ship companies have obeyed the request, in despite the political government over-turning the ban on larger vessels. ${ }^{30}$

The cruise ship is an infrastructure, mega-force, economic engine and enormous object overlapping, looming above a fading Venetian identity. (Figure 15) It might also be a liminal retreat from the conflict of which it is a partial cause. 


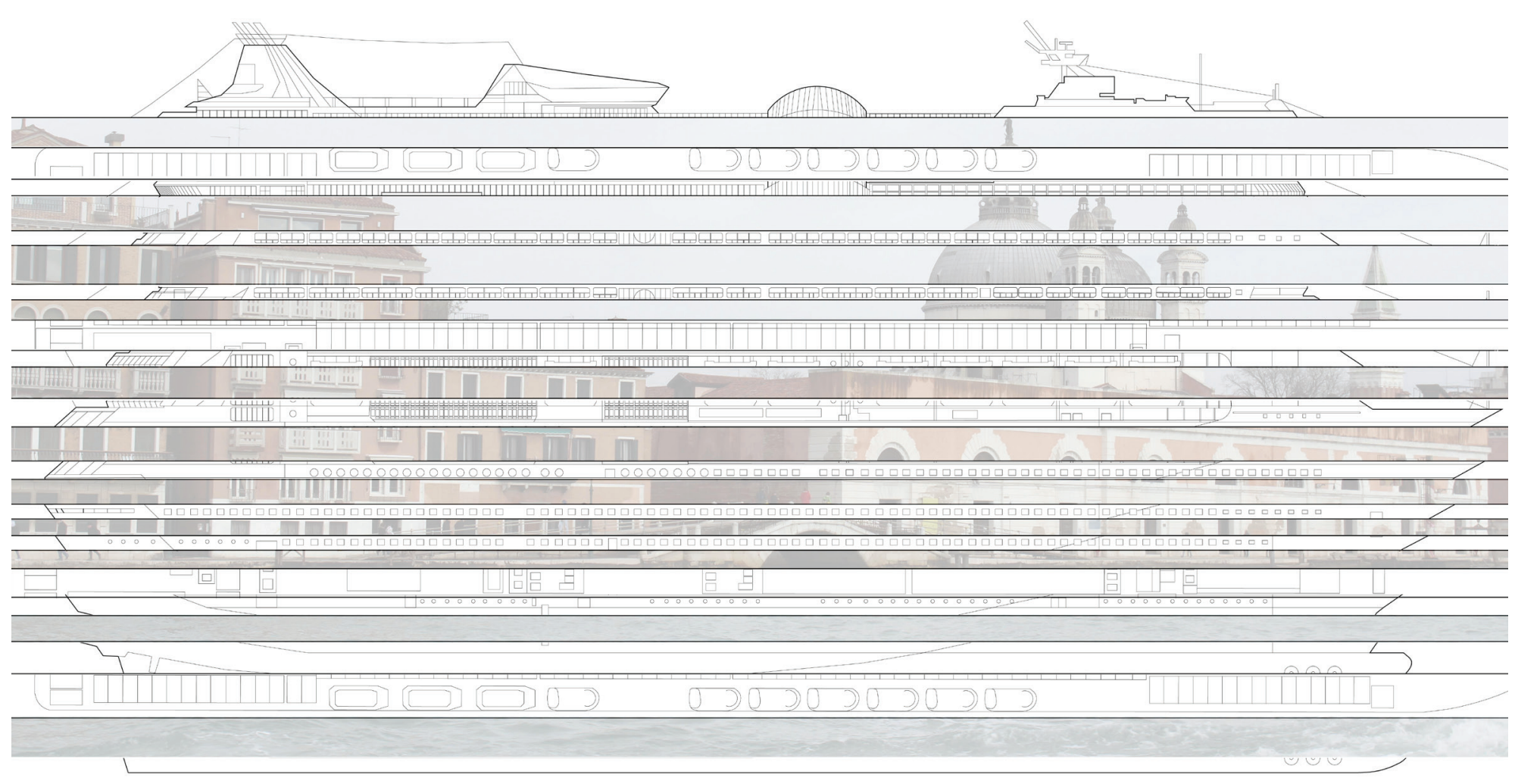

\section{Figure 15: Street and Ship Section Overlay}

City and ship intervene into one as this object becomes the third space, between the cities of Venice. The two are superimposed on each other revealing the in-between, the cross-hatch space. 


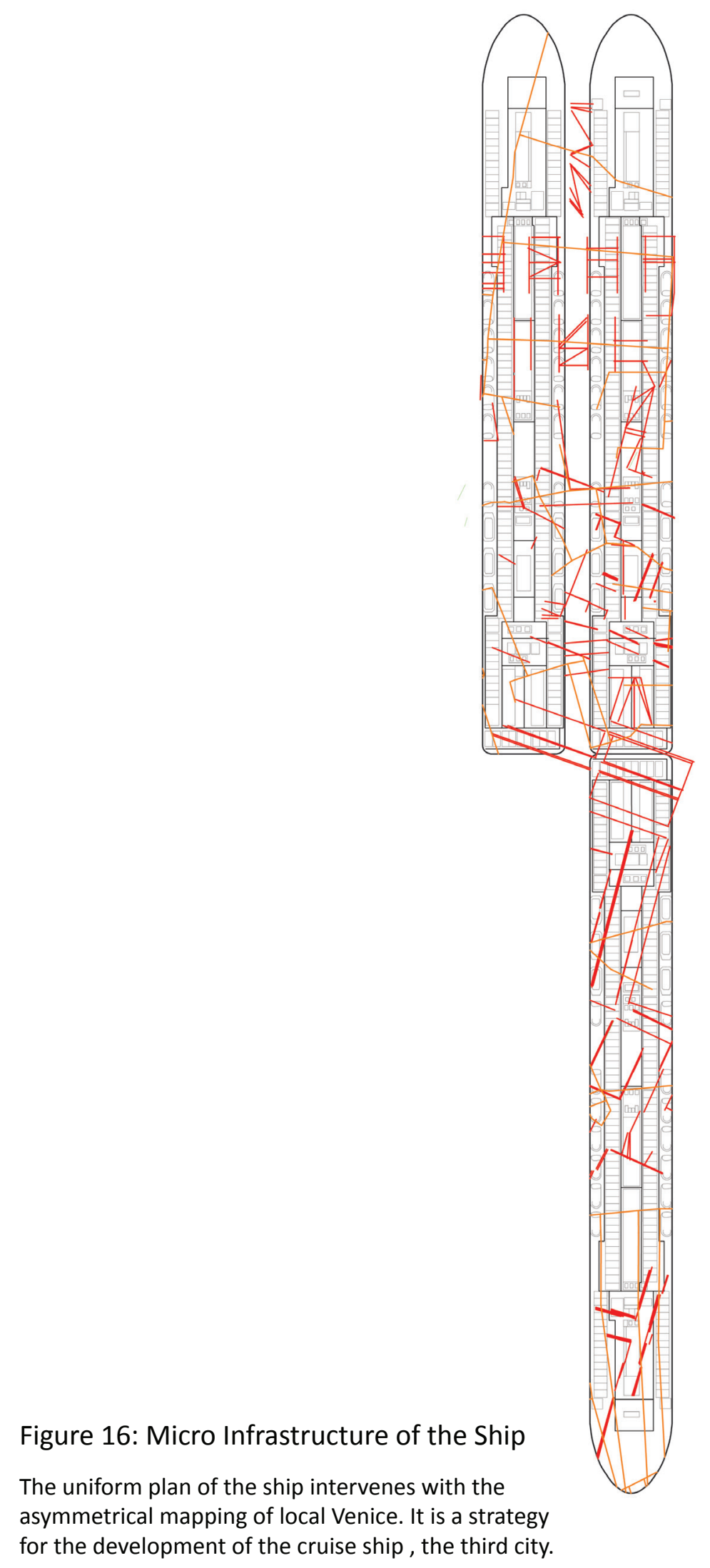




\section{Liminal Space and Liminal Time}

The floating city moves along the edges of other cities, appearing and disappearing within the fog and behind the towers. The ship is unbound to the streets or the canals, nor is it tied to the laws or the boundaries of the two cities. The cruise ship is the third city of Venice, a temporal refuge for its local people. The city will accommodate as many ships as it takes to accommodate the residents. Each ship becomes a transitional-being ${ }^{31}$ a space where the Venetians occupy the ship within a period as the city stabilizes itself. The ships become the ark of Venice.

This is the city of liminality ${ }^{32}$, a threshold following a past identity bound to traditions and rituals of the local people, and before the beginnings of a renewed city structure. Between the states of past and future is this in-between, freeing Venice from any spatial norms. ${ }^{33}$ Like the crosshatch spaces in China Miéville's novel, the third space of the ship belongs to two worlds, more connected to time than to space. ${ }^{34}$ Within this timeframe, a narrative opens to possibilities of an alternative condition, a temporary framework in the anticipation of a future Venice. This liminal time ${ }^{35}$ is a transitional space between real and imaginary, a journey from the current systems that affect the city to a new state whose nature we do not yet know. 


\section{Journal from Aboard}

\section{Part II}

What follows is my personal account of scale, time, sound and space while living on a cruise ships for five days. It is an intermission between the space and time narrative of the liminal Venice, an account of my own experience and observation for my knowledge and understanding of a cruise ship.

\section{Day 1: Embark}

The cruise begins with the arrival to the Miami international port in a taxi, awaiting behind a row of cars as they slowly release passengers into the terminal. Among the chaos of people, my luggage is placed into the pile on the curb as I am directed into the terminal by the crew. I see my luggage thrown onto a conveyor belt and shipped up into the ship above. The shadow of the Navigator of the Seas cloaks over us in its darkness as I look up to the tower, an endless collection of windows continuing up into the sky. Through the terminal I take my place in the queue of passengers, having my documents checked, photo taken and placed into the security scan. The noises of beeping and scanning surrounds me in the main hall as I am directed to the gangway. ${ }^{36}$ My seapass identification card is scanned as I step onto the ship. I leave the stability of land and enter an unknown. 
The ropes are pulled; one-man is seen below tugging the ropes over the mooring bollards ${ }^{37}$, freeing it from the dock. The sound of the horn rings through the speakers, indicating its departure. The engines come to a hum, propellers vibrate the water, pushing the machine sideways off into the channel. ${ }^{38}$ The ship gains speed gliding forwards into the waters of the ocean, swaying slowly - side to side - as the waves break against its hull. Inside the ship I marvel with other passengers at the main promenade surrounding me. It is a collection of a three-story high passageway with shops, dining venues and cabins spanning the length of the ship. I am oblivious to the choreography of the crew below as the machine comes to life moving slowly towards our destination. Level upon level, the passageways of the ship keep going, door after door, blurring into one, each identical to the next. As I look for my room walking down the dim light hallways, I lose my perception of my position on the ship. The room numbers rise towards the front, the corridor bends, around a column as it leads to the door of room 6425. (Figure 17)

The bed swings down from the ceiling, creaking into place. I can hear the mumbling of the next-door passengers opening and closing the balcony door. The cabin consists of a collection of furniture - a desk, cabinet and nightstands fixed to the rooms edge. ${ }^{39}$ Outside the waves shatter against the side, spraying the salt water onto the balcony. The ship slices through the water, gaining speed as I feel the rocking while sitting and observing the sea. 

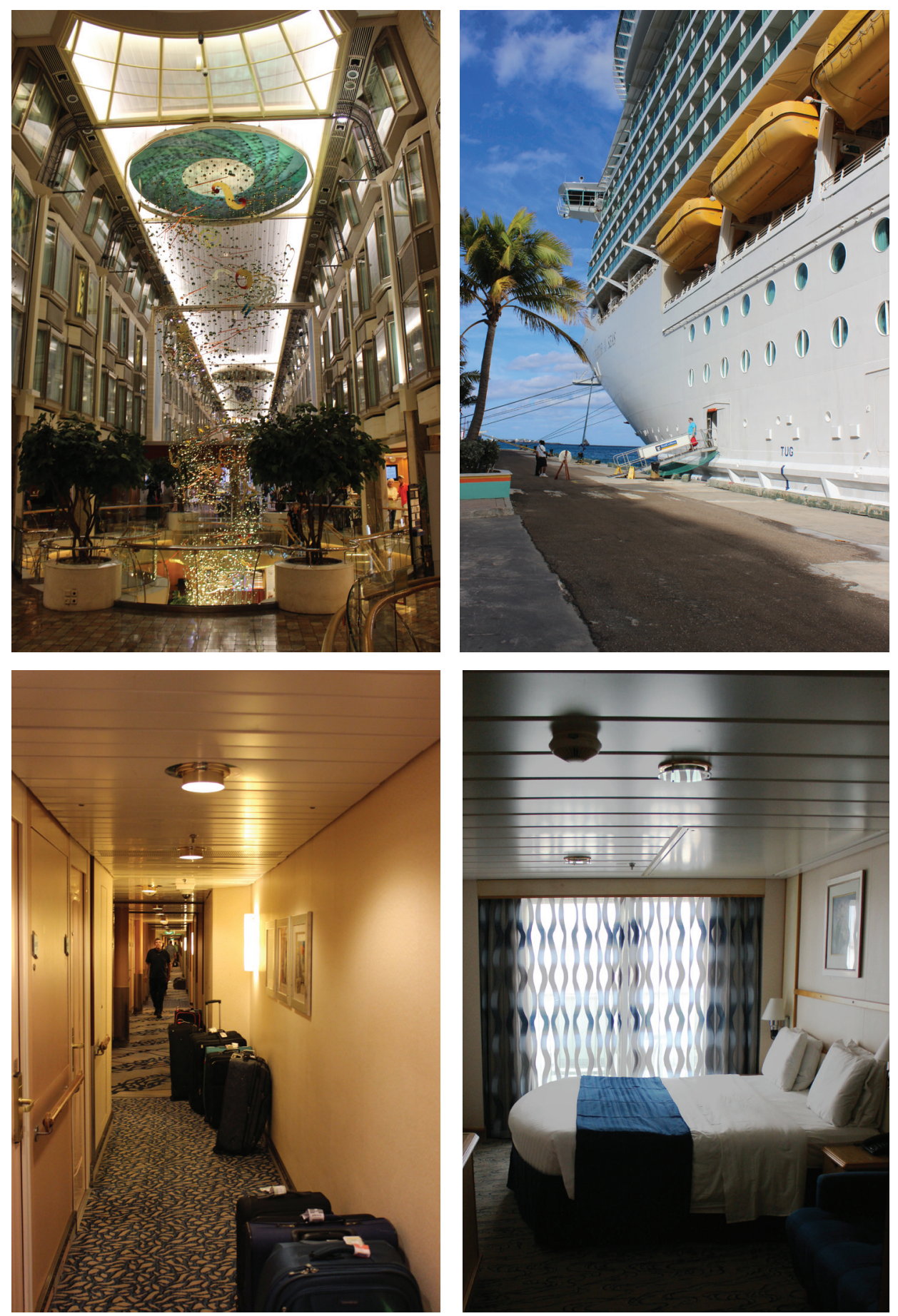

Figure 17: Journey on the Ship

A collection of photos on the cruise ship. Interior and exterior conditions, thresholds and living quarters that can be related back to the conditions seen in the city; streets, piazzas and apartments. 
An announcement is made; an evacuation drill is required to be completed as we head towards the open water. The sirens begin, seven small beeps following a long beep as the emergency practice drill fills the cabin. I take the stairs and gather with the other passengers onto deck four at my muster station. ${ }^{40}$ One by one we are directed into individual lines and await the speakers to indicate our next movement. The life jackets and lifeboat procedures are explained through the speakers as the crew members narrate the action. Above the muster station the yellow pod sways along with the ship, each having the capacity for 32 people ready to be deployed into the sea. The drill ends, the side doors are open and I follow the other passengers to back into the ship, past the casino and into my room as the ship continues to gain speed passing the edge of Miami into open waters. 
Day 2-5: Cruising

The ship sways back and forth, I stumble along the passageway of the ship as I head to the main street promenade. The ship is a luxury hotel, awaiting my presence, pulling me into the planned activities of the day. The smell of the food, the chatter of people and the splashing of water drifts down the staircase into the passageways of the ship. I climb towards the top, up and around, until I see a blue sky peaking beyond the door up ahead. Outside the wind howls through the upper levels, pushing against me, pulling me back into the stable depths of the ship. Each level is a maze with theaters, ice rinks, kitchens, cabins, gyms and dining halls. ${ }^{41}$ The chimneys spew dark smoke as 3200 passengers and I take over, moving throughout each section of the ship. I drift through the levels, stumbling, trying to stabilize myself as the cruise plows forward to its destination. ${ }^{42}$ I take to the streets of the ships, exploring each program element, pass the helicopter pad, the rock climbing wall, the library and the pools. The collective noise of the thousands of people is drowned by the creaking of the walls, the chimes of the elevators and the humming generators powering the machine. 
In the ship excursion of the all access tour, the lower decks are toured, the backstage of the ship along the main passageway, I-95. ${ }^{43}$ (Figure 18) The three decks below the water line (tween deck, tank top and lower bottom) are the life lines of the ship where the endless dinners are made, the garbage is sorted and the mechanical rooms are monitored. The tumbling of laundry, the crushing of cans, grinding of uneaten food, beeping of the equipment echoes across the passageway as its crew continue to support the machine. Above on deck eight the captain sits at the bridge, observing the waters, looking at his first officer as they monitor the wings of the ship. The screens of the radars, fire compartments and navigation tools are organized along the main surface of the bridge. The blinking of lights on the panel is monitored, the steering controlled by the autopilot. The ship continues onward to its port, its crew continuously working, monitoring and feeding the ship.

\section{Day 6: Disembark}

The rocking of the ship decrease as the ships speed slows; its engines turn pushing the ship towards the dock. I step out into the balcony watching as the ship turns 180 degrees reversing back into its spot against the buoyant fenders ${ }^{44}$. On one side, another ship is anchoring securing its lines across the pier. Slowly the machine pulls into place, disembarking as the lines are expelled from the hull onto the mooring bollards below. The port crew catches the lines securing them at the steel bollards, crossing them across the pier. The announcement is made; we have docked the doors are open for my disembark on deck two. I wait in line behind the queue of passengers as the gangway is pushed onto the pier. I cross the threshold of the ship; my sea pass is scanned as I return to the stability of land. (Figure 19) 

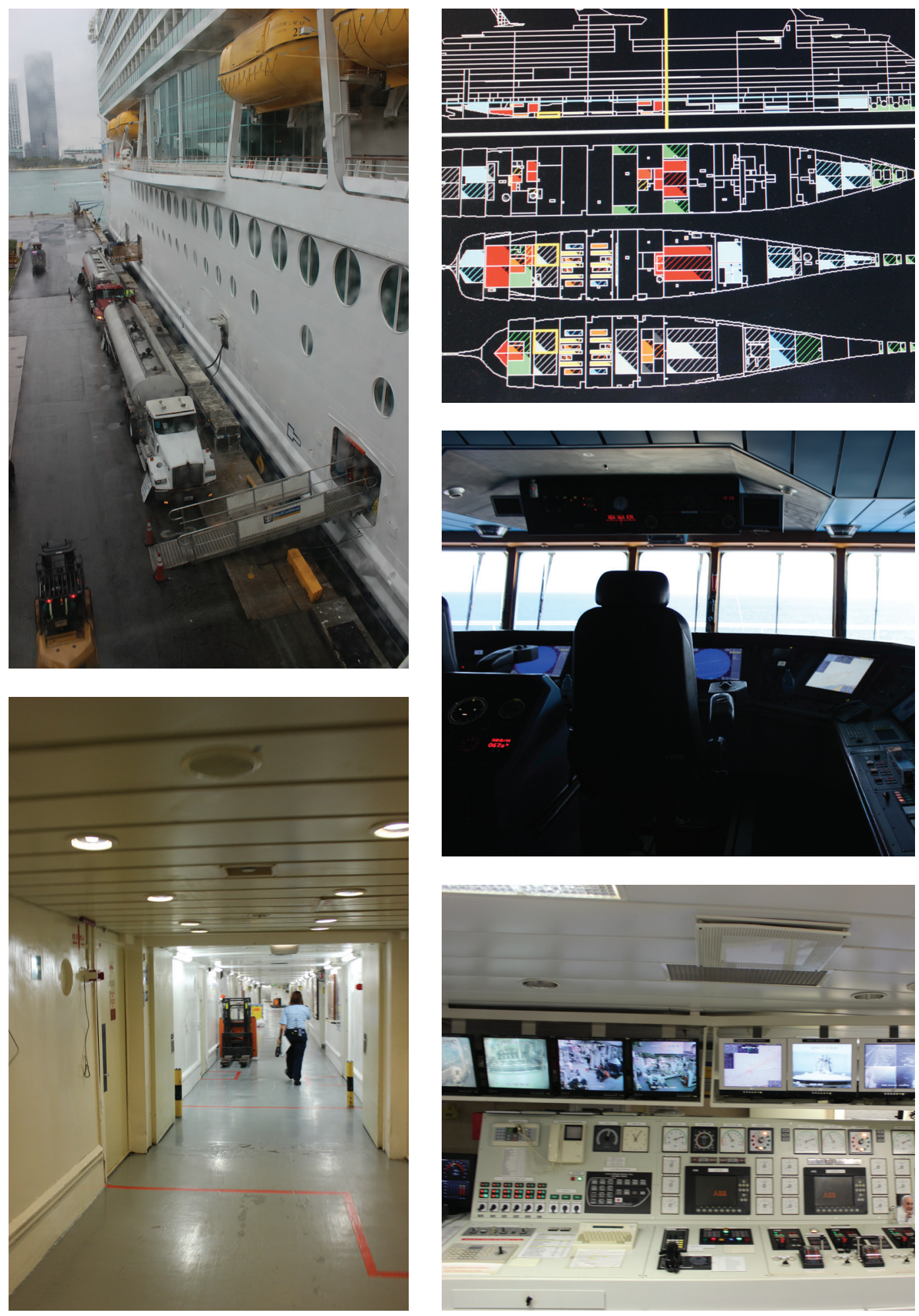

Figure 18: All Access Tour

A collection of photos during the tour of the crew areas of the ship. From left to right: ship loading, fire compartments, I-95 passageway, captains bridge chair and mechanical monitor room. 

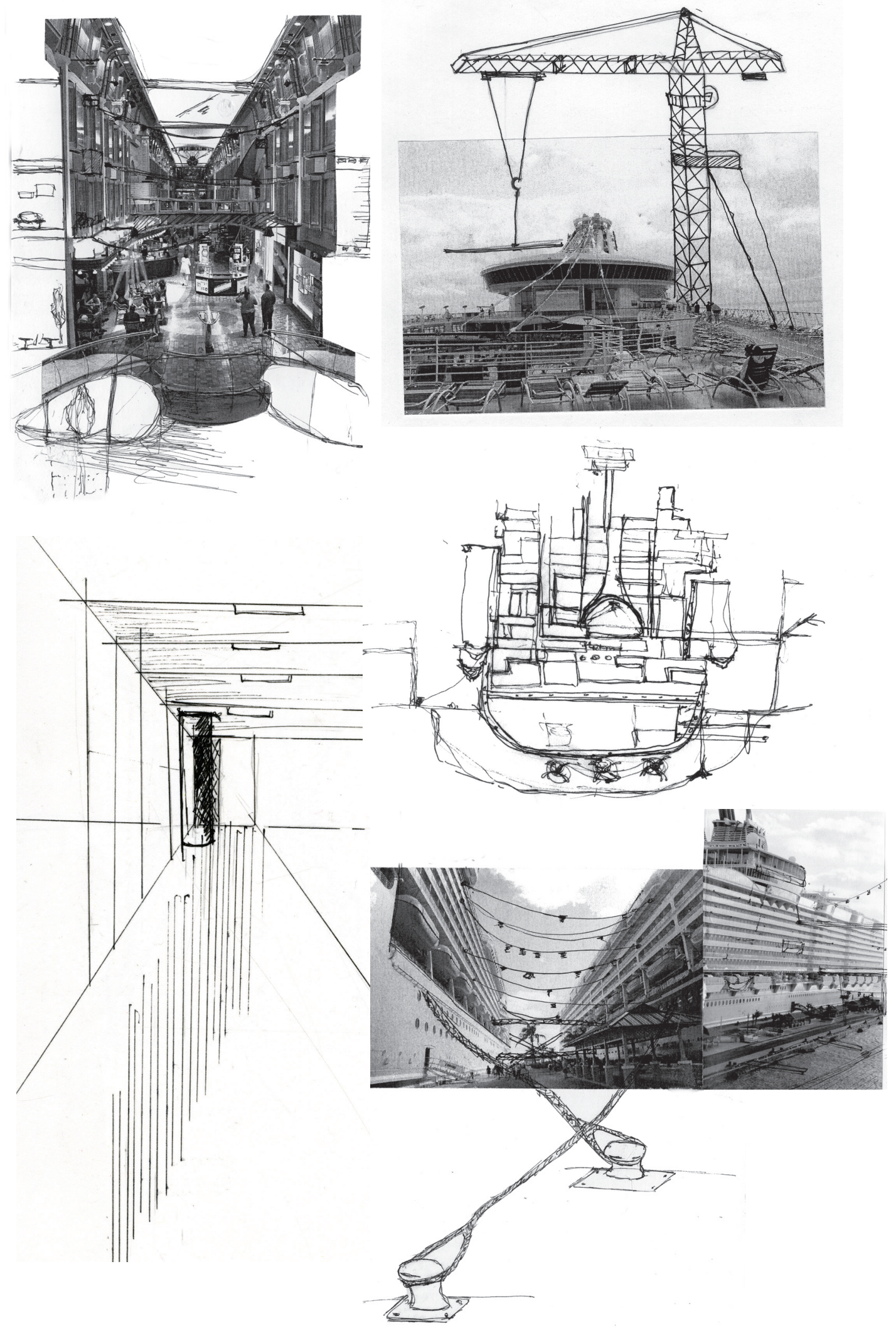

Figure 19: Sketches from Aboard

Design interventions within photographs for a possible new street, piazza and apartment. From left to right; interior promenade, upper deck, interior passageway, new ship section, new street 


\section{Liminal Time}

Part II

What follows is a narrative consisting of six stories within a span of 30 years and beyond. Within this liminal period of Venice's history, Venice becomes a constructed landscape in a city of cruise ships, an ecological, economical and social strategy to complement the stabilization of Venice's fragile structure, and to support the culture of its population. ${ }^{45}$ (Figure 20) 


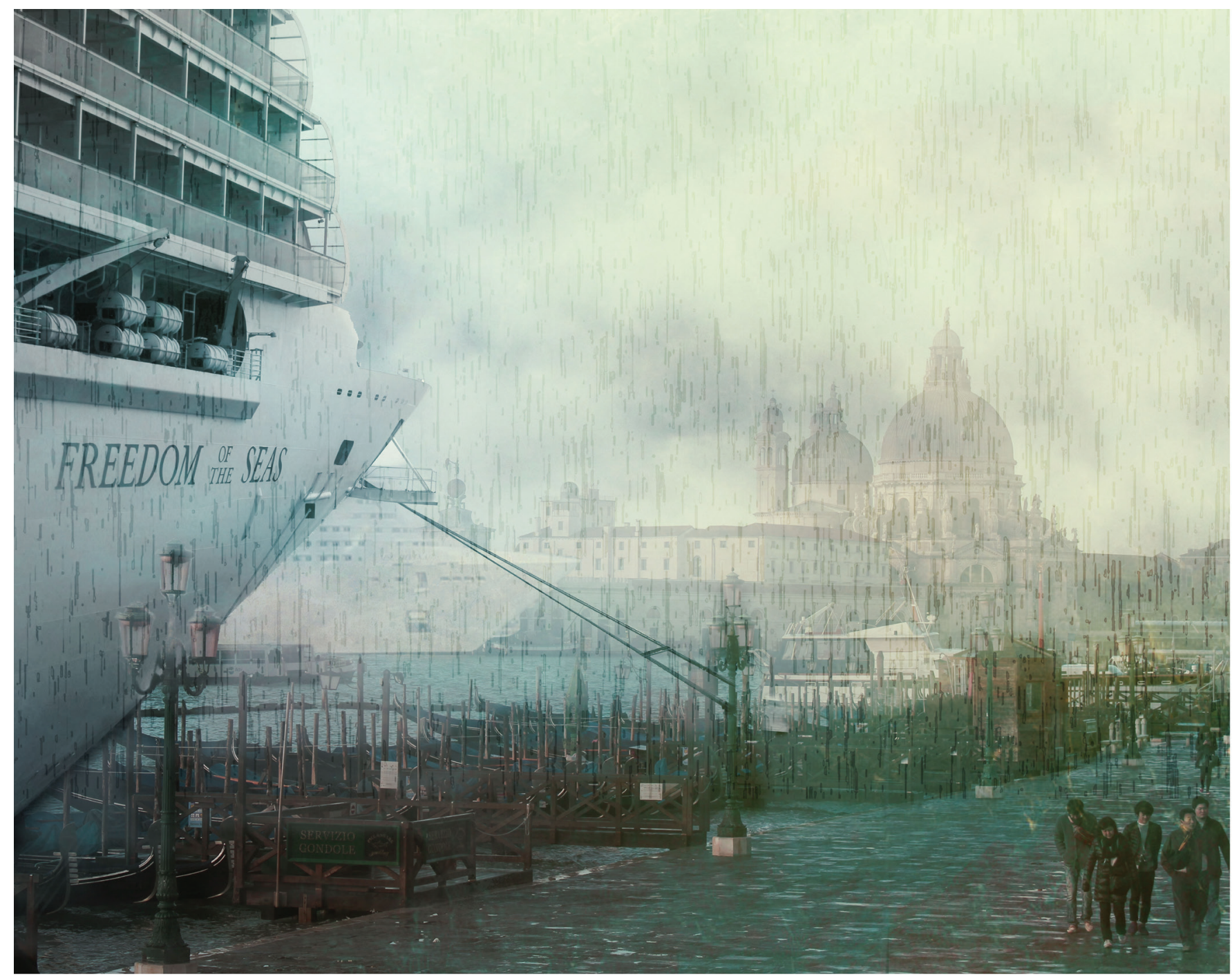

Figure 20: Venice

The narrative begins with the Venice of today, the ships unchanged within all the cities of Venice, looming above the streets. 


\section{7: Preparation}

Against the silence of the city, in the early morning months before the arrival of a fleet of cruise ships, a low hum echoes across the water as mud is pumped from the depths of the canal. ${ }^{46}$ The machines plow through its waters, dredging along the shore line where the ships will dock for years or for decades, the city carving new space for its relocated neighborhoods. (Figure 21) Adriatico,

${ }^{47}$ a bucket ladder dredger, digs from anywhere between one and eight meters below the water line, smoothing the basin beneath the surface. The dredging occurs around the perimeter of the city an area of $4.97 \mathrm{~km}^{2}$. (Figure 22) It also dredges to other places selected for the ship such as the waters close to the island of San Michele. What to do with the mounds of mud? They stretch along the coast; months of dredging create new islands, an archipelago of silty sand. The additional silt is transported to the abandoned islands of the lagoon. On the horizon, large cranes are pulled on ships who recede into the fog.

In this preparation for Venice's liminal time, the cranes offload wooden slabs, piles and equipment from barges that rally to and from the mainland. Thousands of long wooden piles are driven into the lagoon past the mud into stable ground. New piers are constructed along the edges, where the dredging has made space for the ships. Each of the six sestieri has its own connections to this new infrastructure, soon to welcome an accommodation for its residents. 


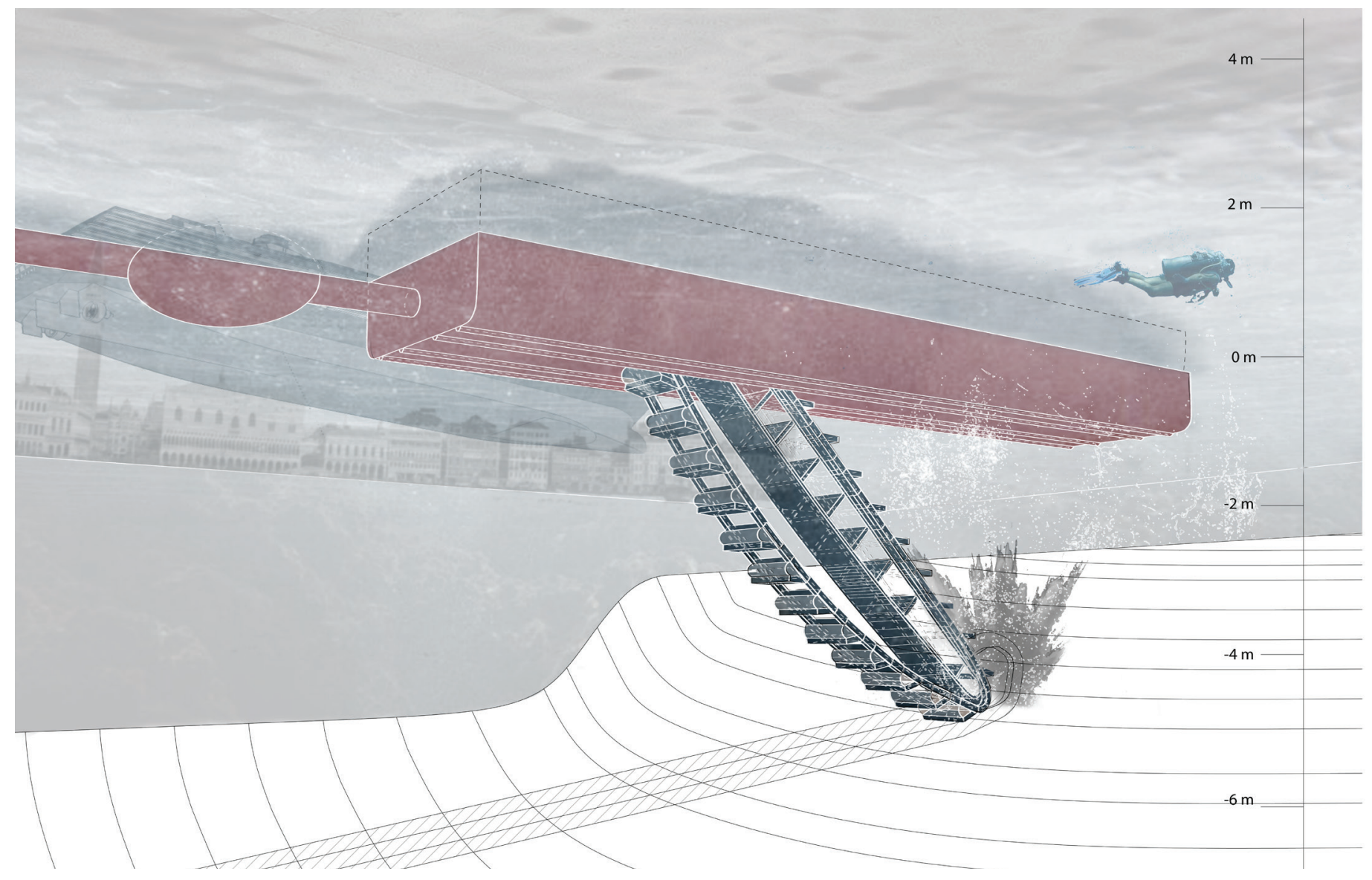

Figure 21: Dredging Machine

Adriatico, a bucket ladder dredger, digs below the water line, smoothing the basin beneath the surface. 


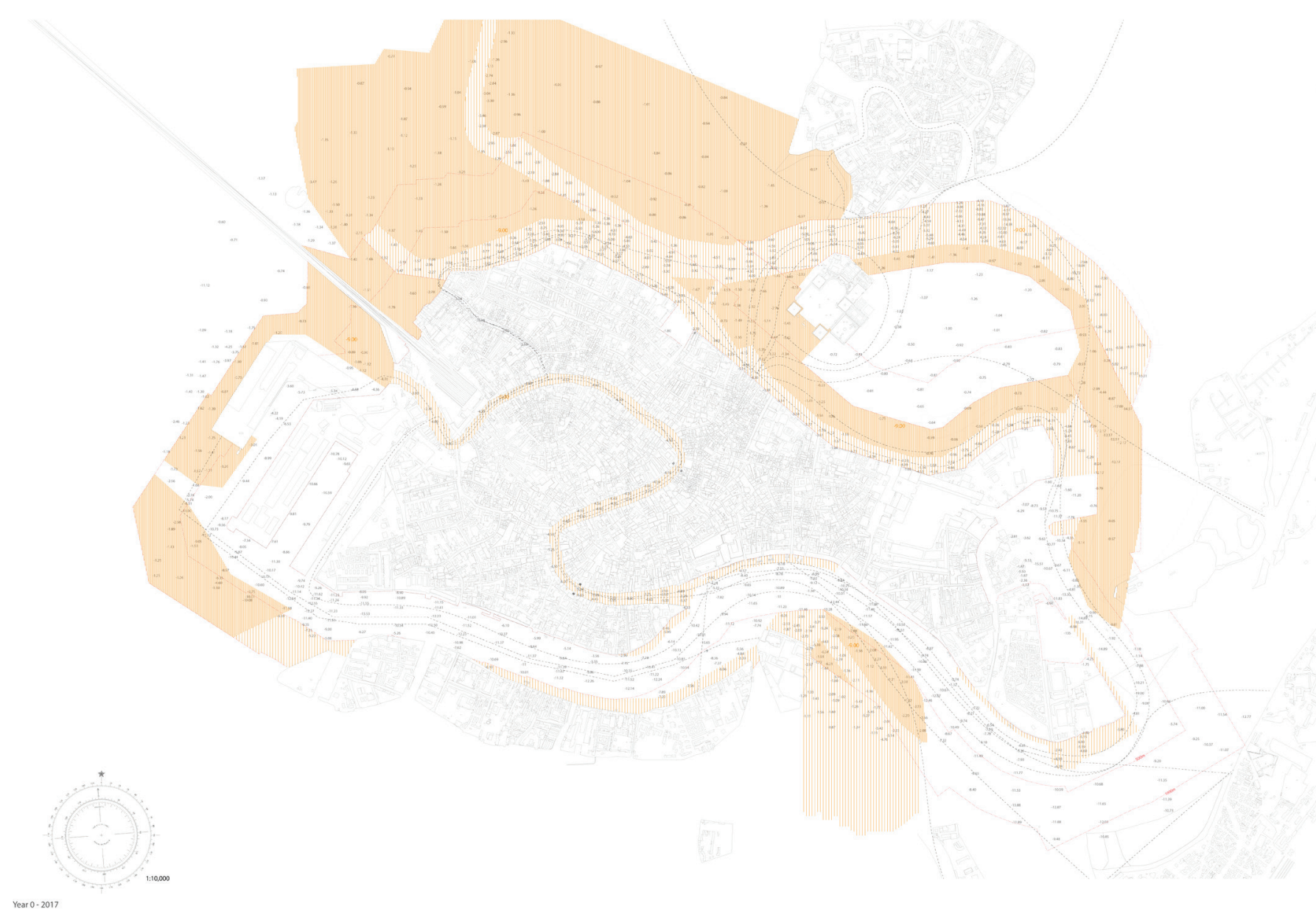

Figure 22: Dredging the Lagoon

The machines plow through the waters dredging along the perimeter of the city, digging below the surface in preparation of the ships who will dock. The bathymetry map is altered as the machines dig deep into the lagoon.
Dredging Required

1-4 m

$4-8 m$ 
Along the Grand Canal, tower cranes assemble at the Rialto Bridge; large cables wrap around the bridge and prepare to lift it high above the water. (Figure 23) Smaller cruise ships will enter here, to be beached as the canal is drained of water. Lifting the bridge 20 meters is a spectacle, a surreal moment. The city continues to add, to move and to shift its land, water and infrastructure, in preparation for the white vessels to come. 


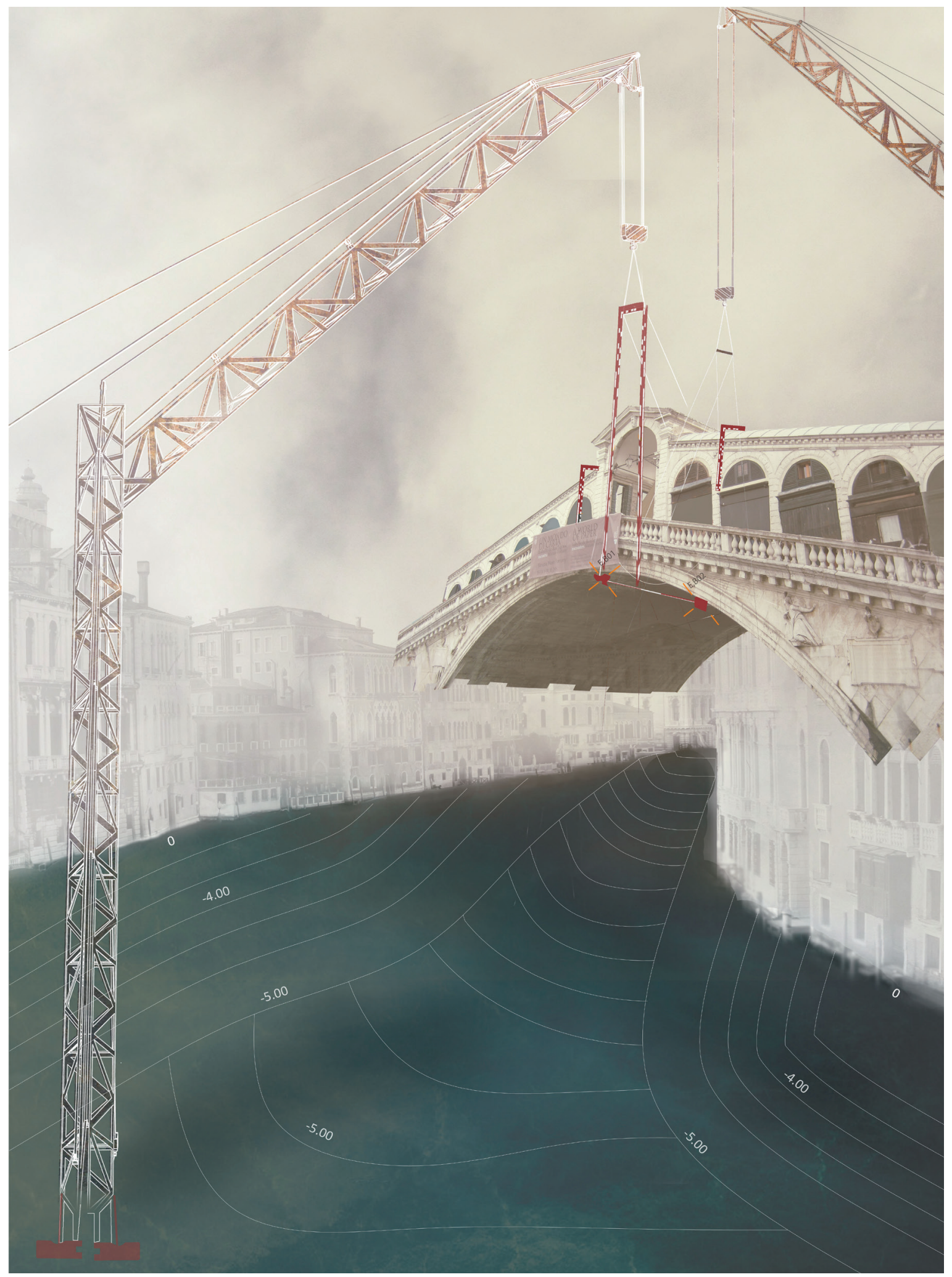

Figure 23: Lifting the Rialto Bridge

Large cables wrap around the bridge lifting it high above the city. Elements of the archaeological map are reintroduced as hinges within the liminal time. 


\section{2: First Exodus}

A ship's whistle rings through the streets of Cannaregio, San Marco, San Polo and Dorsoduro, awakening the residents. The ships glide in under a cover of darkness, waves break against the streets, rocking the gondolas in the canals. The smaller ships move into the Grand Canal, past the hanging bridges, docking in place. Twenty-six vessels of varying sizes are berthed around the city, each connected to its sestiere. ${ }^{48}$ (Figure 24) The engines come to a stop, the anchors are dropped, the ropes are fastened and the gangways lowered. All of this happens over the course of three years.

The exodus begins in the neighbourhood of Cannaregio. The Venetians pull their luggage along the quieting streets, the lines of the ship are secured onto the mooring bollards. Suitcases are placed onto conveyor belts and staterooms are assigned. They pack up their belongings awaiting the ship. (Figure 25) The doors of the lower deck are opened; pallets of provisions are loaded. Venetians climb the gangways, and cross the threshold of one city into another.

Over the years, one neighbourhood at a time, the Venetians take up their new residence aboard. The ships are renamed for the sestiere. (Figure 26) The old streets grow quiet, except for the construction workers, who dig deep beneath the foundations to make their repairs. The cruise ships absorb the daily

life, finding their own accommodation for hanging laundry, for small gardens, and even for shutters that open and close with the patterns of the sun. 


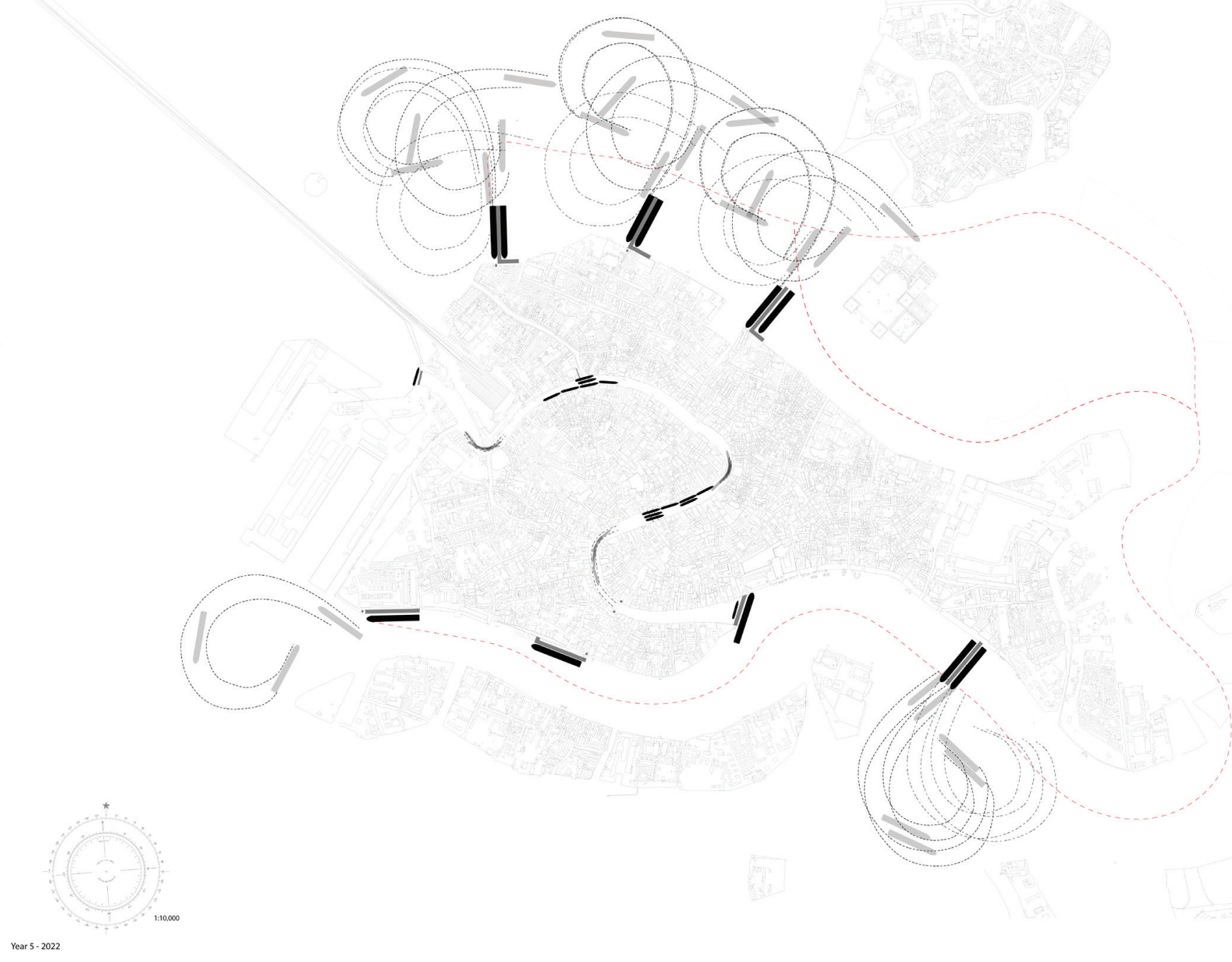

Figure 24: Cruise Ships in Venice

The twenty-six ships dock into the city each connected back to a sestiere. Their turning circles reveal their movement into their specific position. They are linked back into the city with new streets of piers and bridges. 


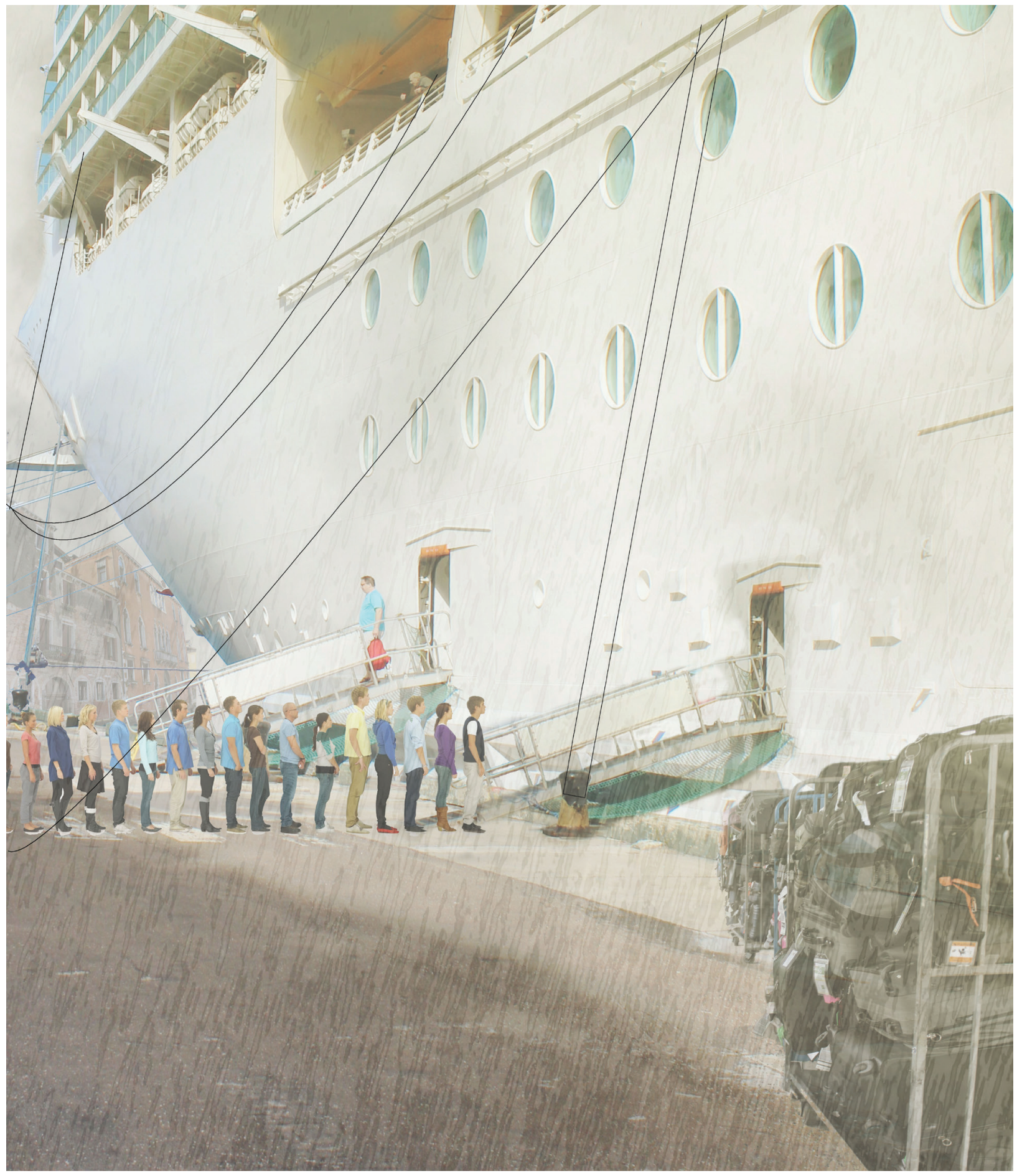

Figure 25: Arrival of the Venetians

The lines of the ships are secured, the ships arrive into the city. Venetians climb the gangways, and cross the threshold of one city into another. 


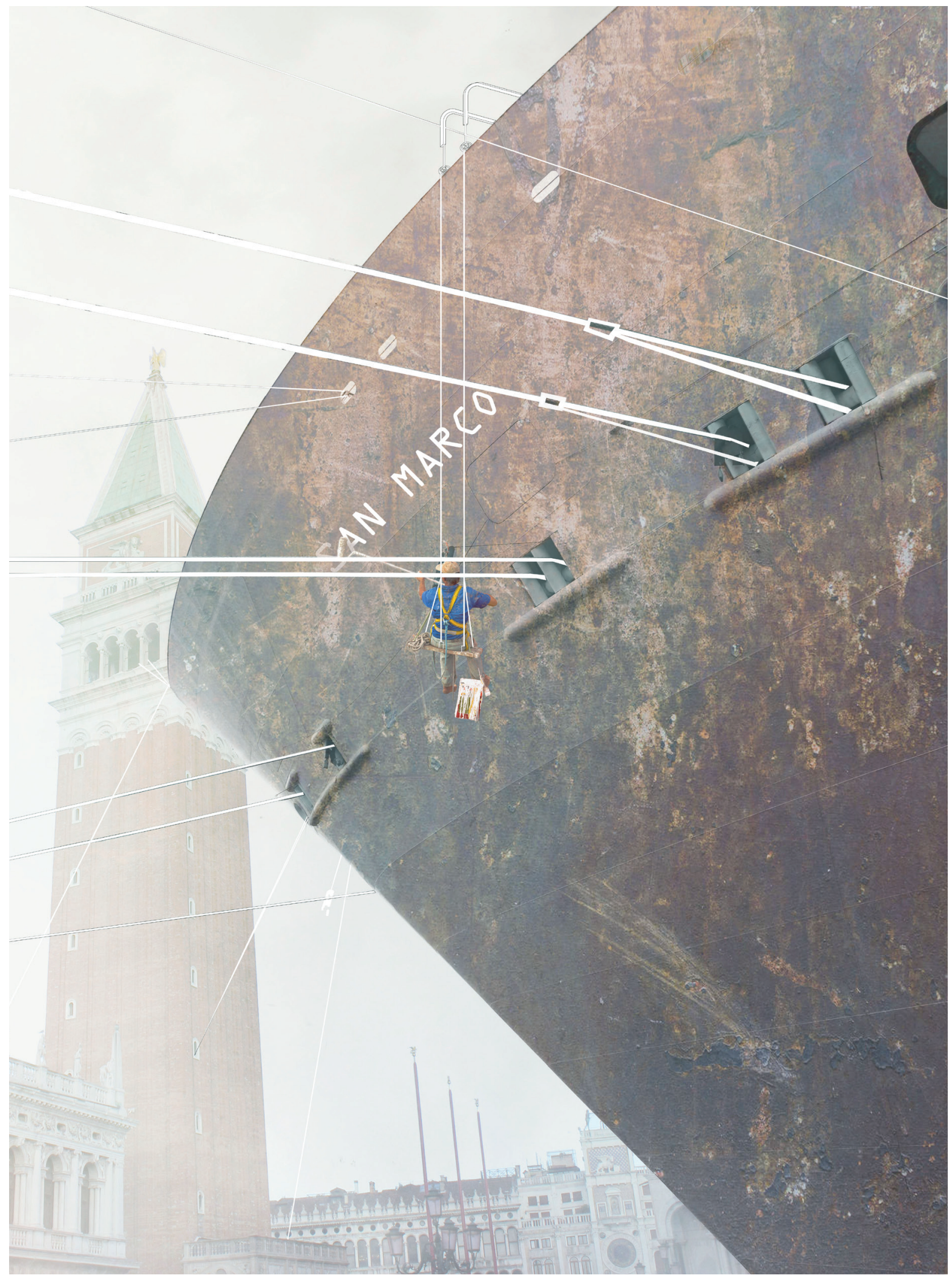

Figure 26: Renaming the Ship

The cruise ship (Freedom of the Seas) is renamed to the sestiere of San Marco. 


\section{6: The Daily Life}

The smell of espresso drifts through the piers at the break of dawn. On board, clothing lines hang between pairs of ships that form the sides of a new canal. Balconies have been enlarged, staterooms have been joined and reconfigured, decks are now piazzas - the result of entrepreneurs opening informal cafes, bakeries and sewing shops (Figure 27).

A network of suspended bridges connects the vessels to each other, allowing residents to cross over into other "neighbourhoods." (Figure 28) Round windows glow in the evening. (Figure 29) Smoke issues from the some of the cabins that have been fitted with small heating stoves. A great white wall, broken by moments of architectural invention, stretch along the piers, and the sounds of the Venetians can be heard in the markets (decks and dining halls) and echoing through the passageways. Passageways now zigzag through the ship, forming the narrow streets that open to bridges and public space. Small shops line the open promenades. (Figure 30) 


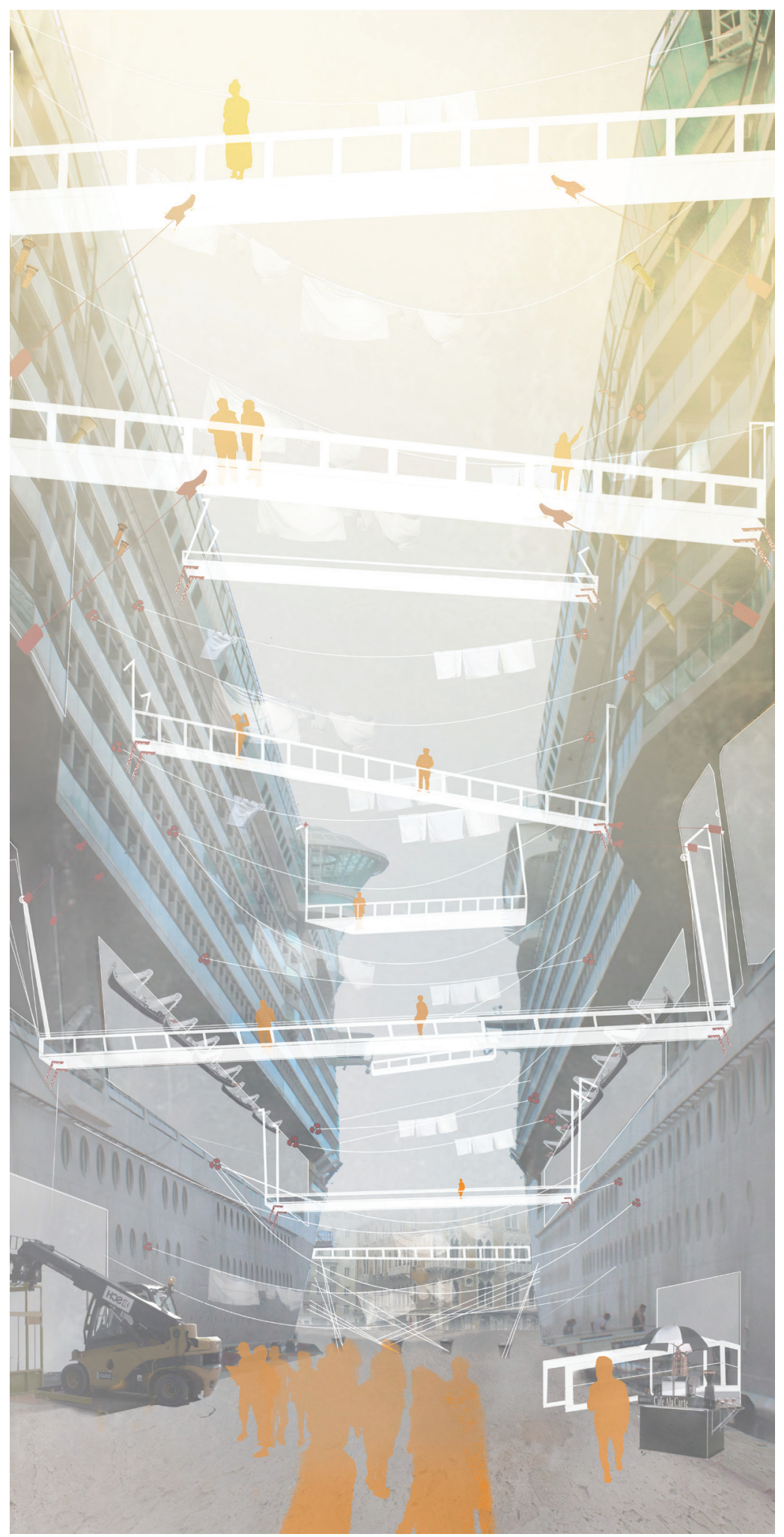

Figure 27: Street Between Ships

A network of suspended bridges connect to each vessel allowing its passengers to cross over to other neighbourhoods. 


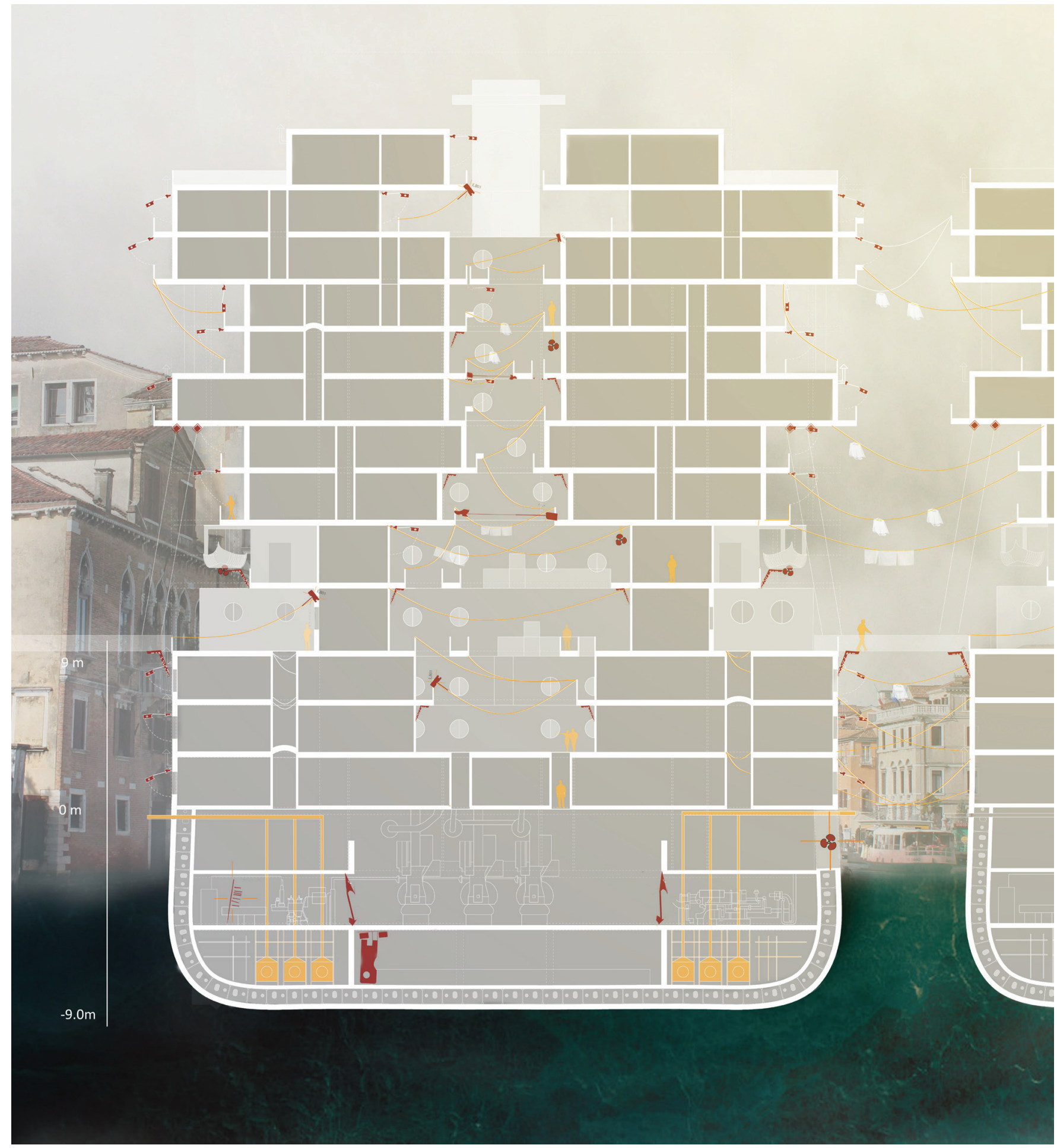

Figure 28: Section of the Ship

The monolithic ships is transformed, state rooms have been joined, balconies have been increased. An interior promenade opens above, spanning the full section of the ship with balconies opening into the passageways, allowing light to fill the hull. Shutters are seen on each balcony and clothing hangs between the passageways. 


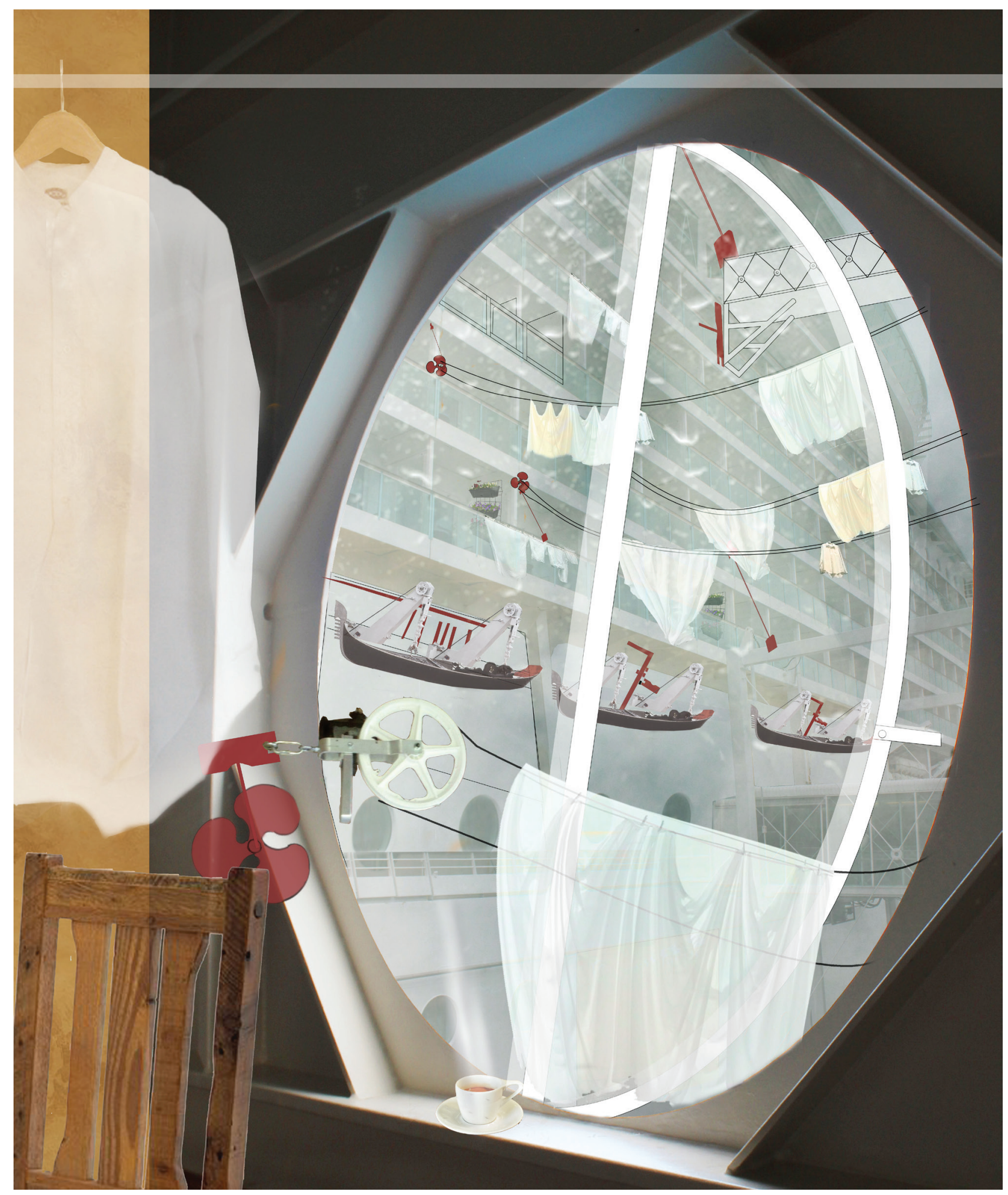

Figure 29: Through the Porthole

Hanging laundry is seen through the porthole of a cabin, gondolas and bridges suspended above the decks. The cabins are adapted for the Venetians that now reside in the ship. 


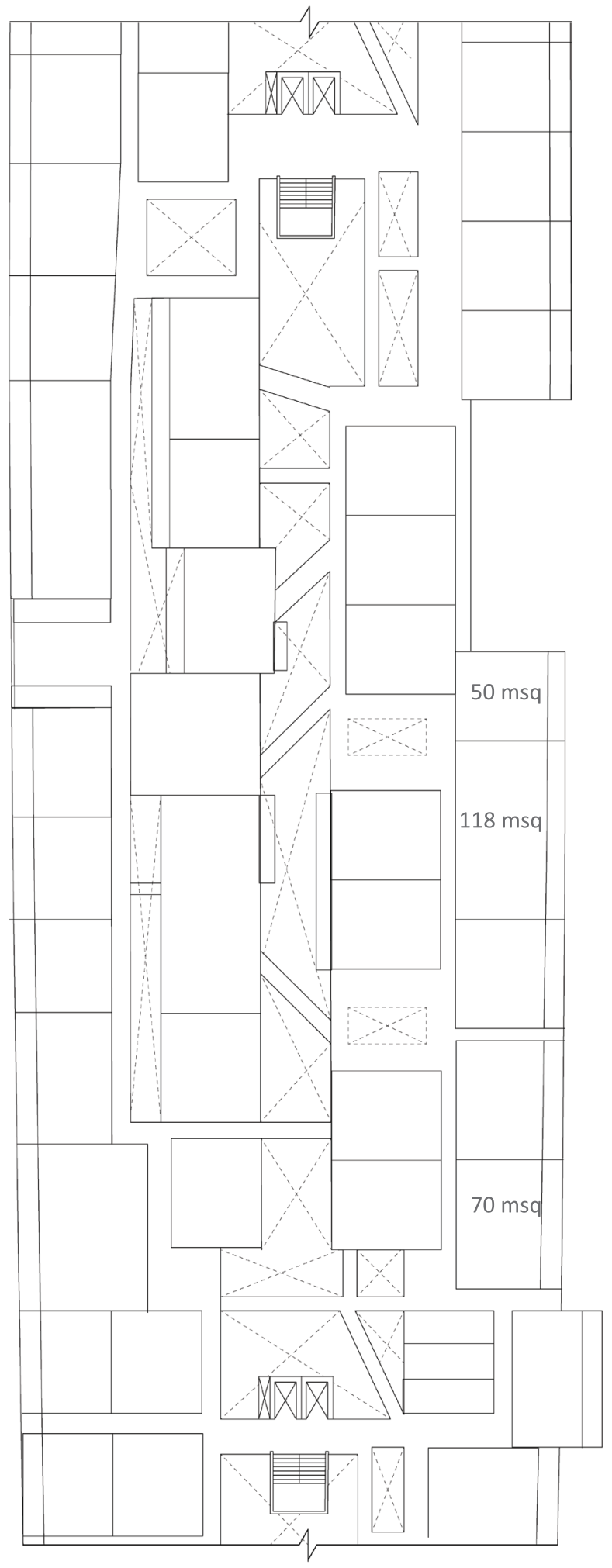

Figure 30: Plan of the Ship

Passageways now zip-zag along the ships connecting to the balconies of cabins. Bridges suspend between the promenades allowing light to fill the depths of the hull. 
Beyond this third city, the old Venice begins its stabilization. Each morning, the construction workers leave the ships and descend the gangplanks, to begin their digging and hammering. They remove centuries of mud, revealing the state of the brick and oak piles below. The first task is underpinning the foundations, repairing and replacing the pilings that have rotten away. (Figure 31) Streets are lifted, and floors are leveled. Decorative marbles are taken down, washed and soaked removing the accumulated years of salt. ${ }^{49}$ Above, scaffolding is placed as white fabric wraps around a facade during the addition of new layer of stucco.

Materials arrive by boatloads: piles of wood, stone and brick. Among the foundations are temporary workshops for the underground reconstructions, including the city's water system. On the streets, crews repair the paving stones, facades, and bridges. From one sestiere to another, construction workers rebuild a city to which they will someday return. 


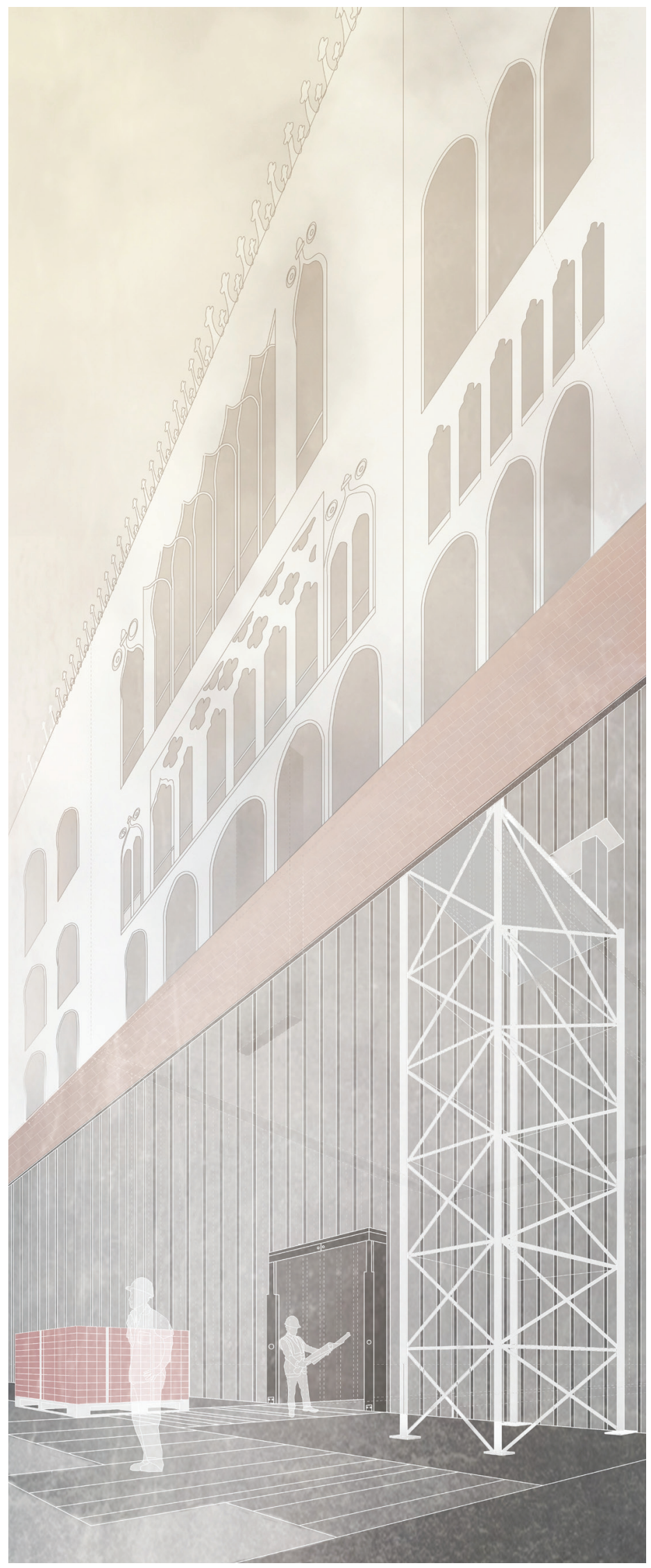

Figure 31: Repairing Venetian Foundations

The foundation of the buildings along the canal are underpinned, bricks and wood piles replaced. 


\section{0: Canal Between Times}

The Grand Canal is being drained. Two ships, one at the San Marco and the other at the Ponte della Liberta, work to hold back the waters of the lagoon. To complete these dams, steel cofferdam walls close the gaps. Water gushes through pumps at either side. (Figure 32) As the water level drops, the smaller vessels moored in the Rialto area settle on wooden blocks. Mooring lines are adjusted to make the ships stable. They are now in a dry dock, within a drained canal that will soon establish its own ecology. ${ }^{50}$ For now, this muddy bed reveals secrets of the past. Lost items-- shoes, sunglasses and maps dropped by tourists from their vaporetto rides-- are stuck in the thick sludge. ${ }^{51}$

The sides of the Grand Canal are the site of major restorations; the palaces are receiving new foundations. Through excavation and underpinning, they acquire temporary basements, zones where construction work becomes visible from the canal bed. ${ }^{52}$ Eroded bricks are repaired, resin pumped into the cracks and foundations receive major reinforcements; Venice is being restored. ${ }^{53}$ (Figure 33)

A boardwalk is built on the floor of the empty canal, five meters wide, sufficient for bicycles, walkers and runners, but narrow enough to allow plants to take over the basin. First weeds sprout from below a forest of kelp. In the coming seasons, a green landscape takes root and fills the empty canal. Some is wild, some cultivated. It is the Grand Canal Park, a deep and temporal topography that belongs to this liminal time. (Figure 34) 


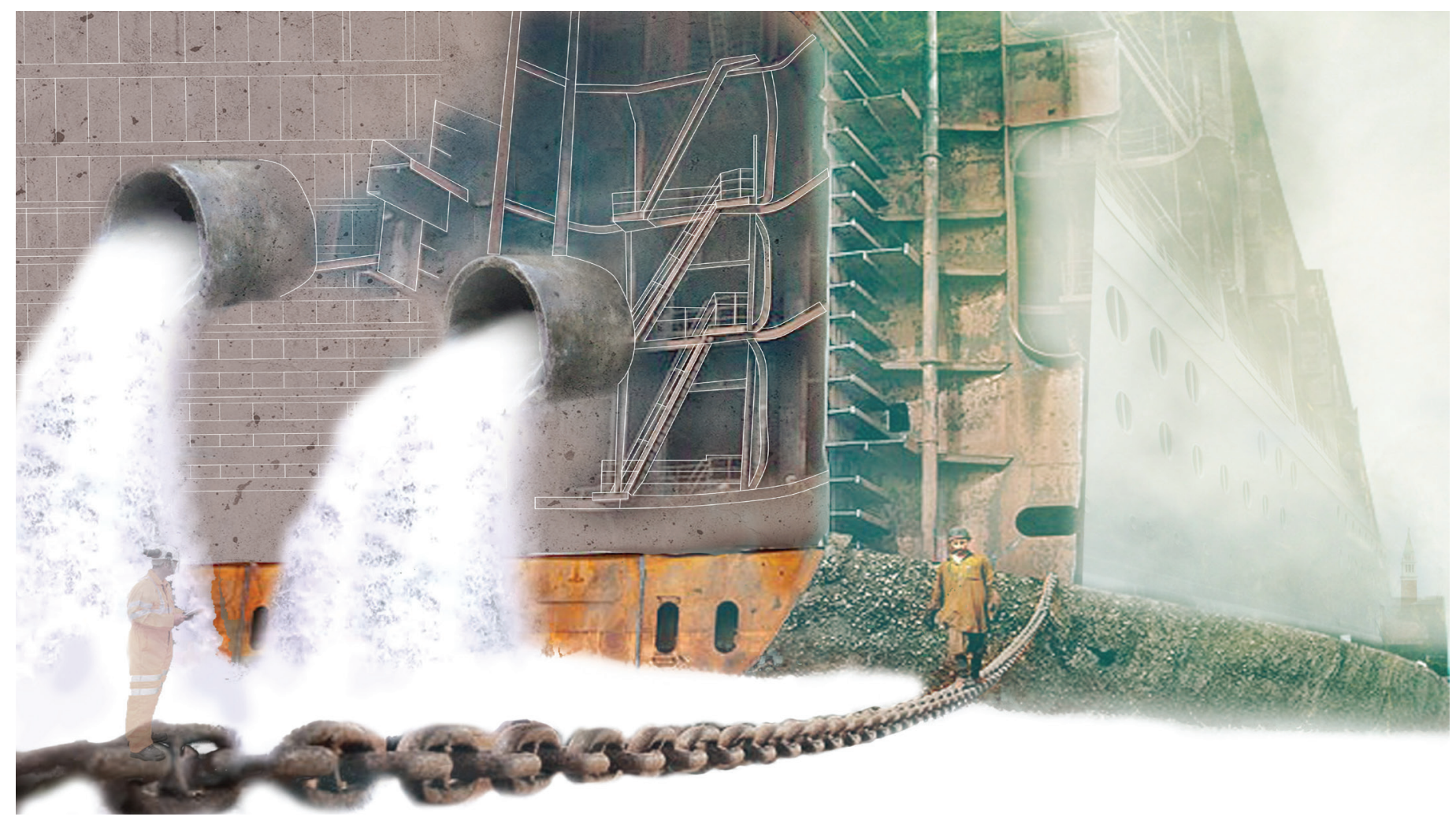

Figure 32: Ship as Dam

The Grand Canal is dredged, two ships at either ends of the canal, pumping water in preparation for foundation restoration. 


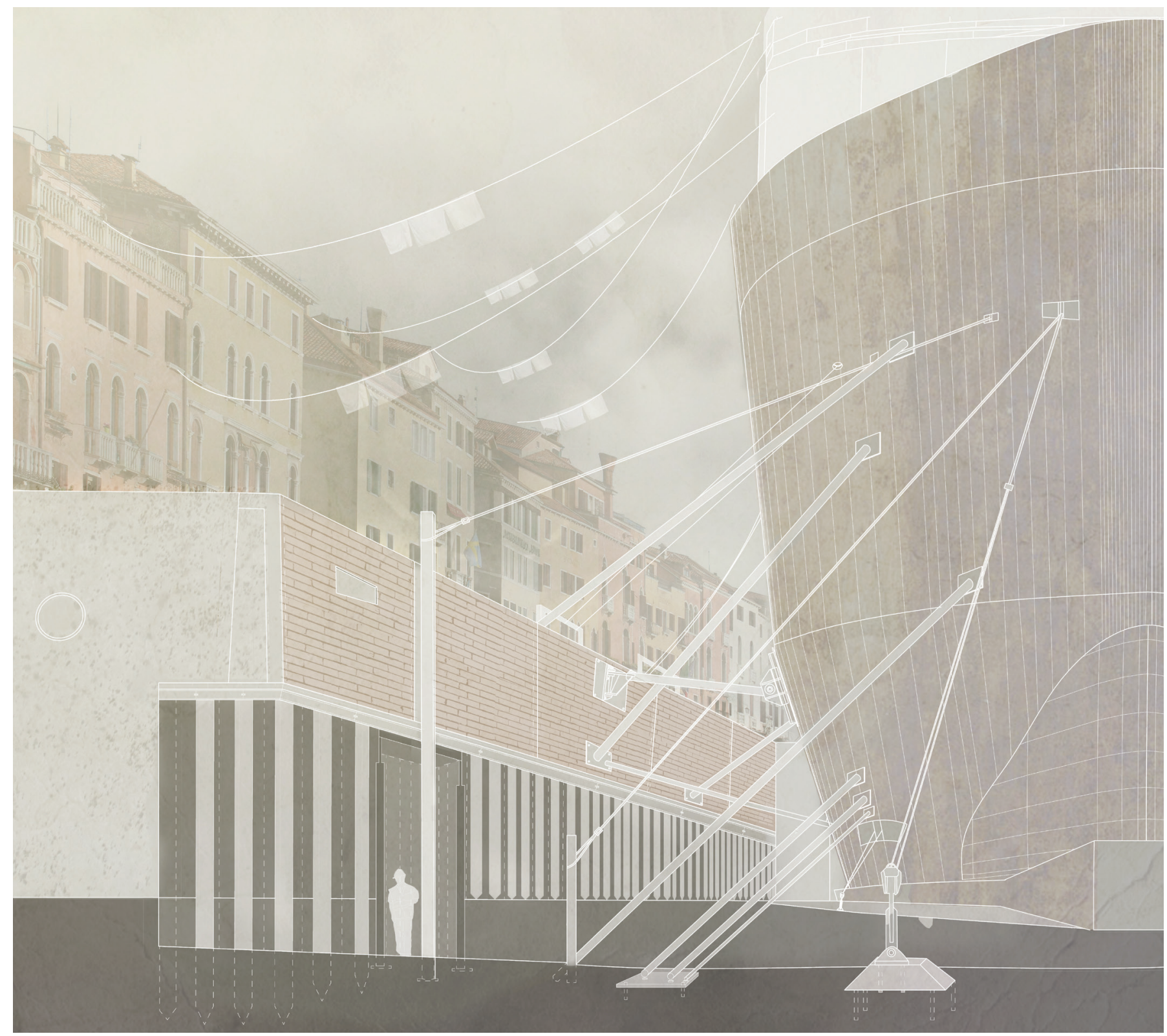

Figure 33: Vessels in the Grand Canal

As the water levels drop and the smaller vessels are dry docked onto wooden blocks, cables are secured to the canal walls. The crumbling state of the walls, eroded bricks are exposed. Temporary openings are exposed between the forest of piles, allowing the workers to repair the city. 


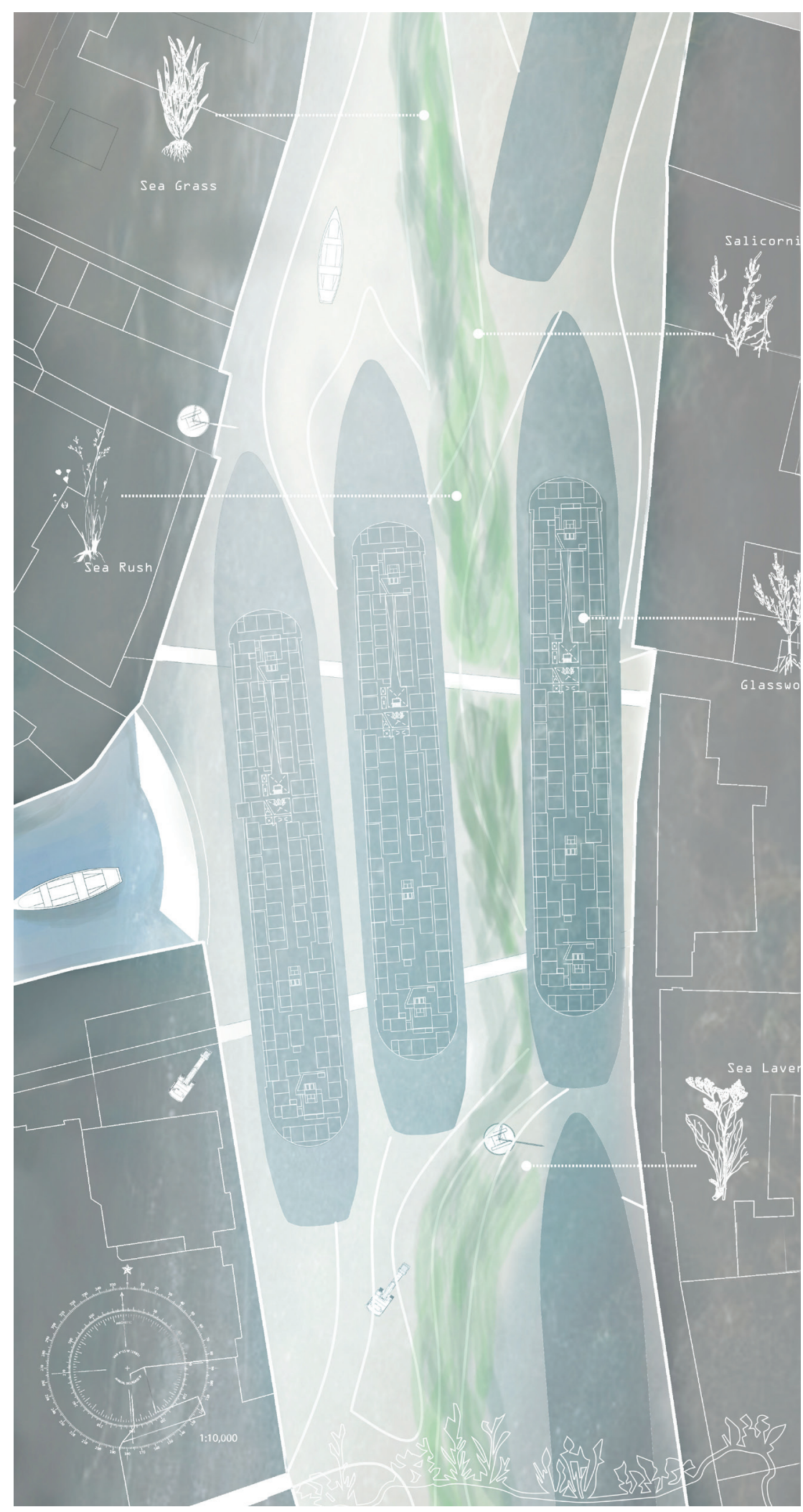

Figure 34: Grand Canal Park

A forest of salty swamp plants sprout from the mud as a temporal topography spreads through the Grand Canal. 


\section{2: Industry Returns}

While the upper decks of the ships have nicely accommodated living quarters, the huge rooms below are obsolete. The diesel tanks, thrusters and proportion motors are removed, and one by one, the cavernous holds are transformed into spaces for traditional Venetian industries. (Figure 35) The glass

makers of Murano, the lace makers of Burano, the mask makers and the gondola builders begin their guilds anew.

In the lower decks of Castello, benches are set within the thick and stable hull. Sand and clear glass crackles in the furnace as a steel pipe gathers a layer of molten glass. ${ }^{54}$ The Venetian blows into the pipe and molds the glass into a cylinder shape, moving back and forth reheating the glass to continuously shape it. Colourful glass hangs around the workshop as glass beads, bulbs and chandeliers are made. The glass blowing studio take over the tween deck of the ship, the heat of the furnaces radiating throughout the hull. (Figure 36)

In the Academia, the humming of table saws and lathers are heard as wood is prepared for new gondolas. The sterns of the gondolas are shaped, rotating among the old ship machines. (Figure 37) The ships welcome this adaptive reuses, where the centuries-old-craft for which Venice is renowned find a new life. In the close quarters of the ships, apprenticeships flourish. 


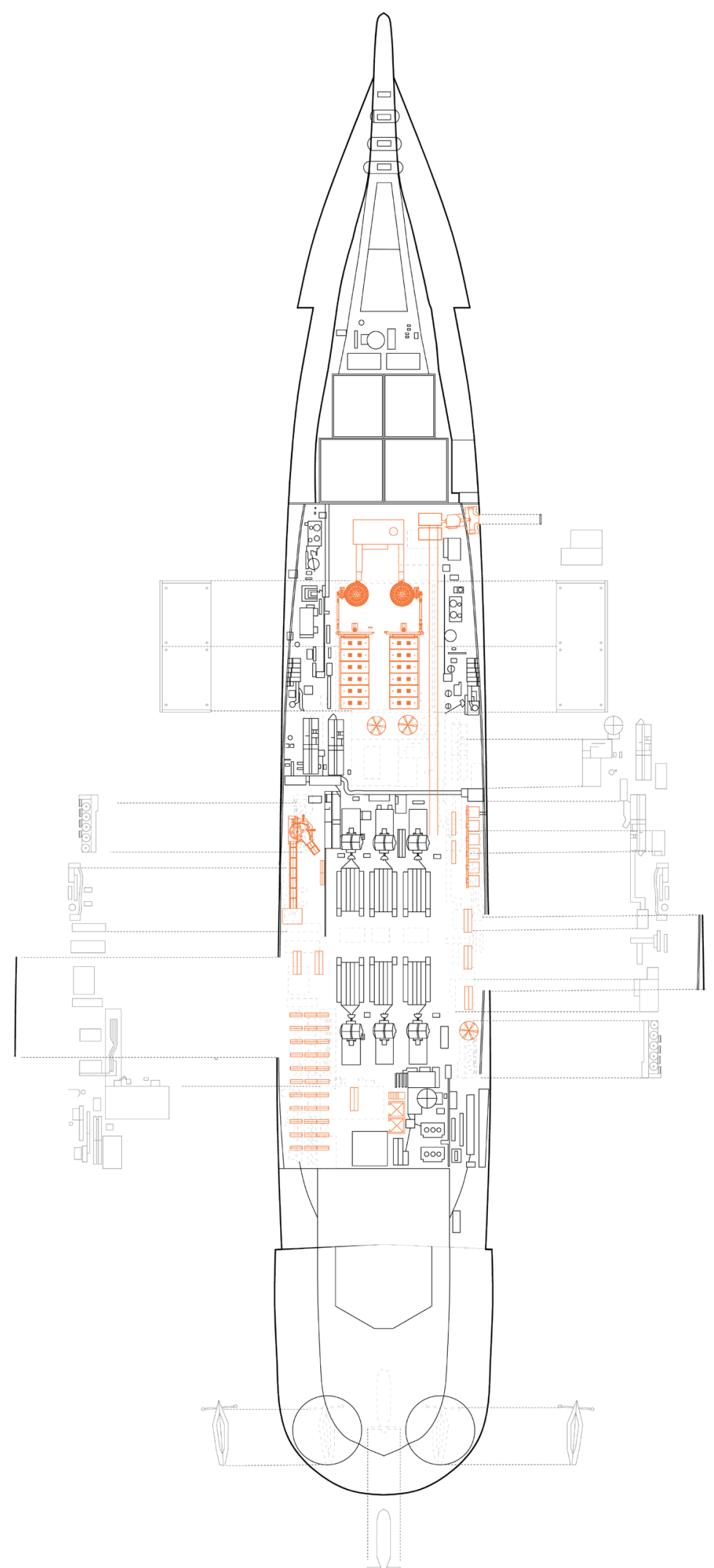

Figure 35: Re-adapting the Machines

The lower decks of the ship are re-adapted, the propellers, diesel tanks and thrusters are removed and in their place machines of traditional craft are inserted through the new openings. 


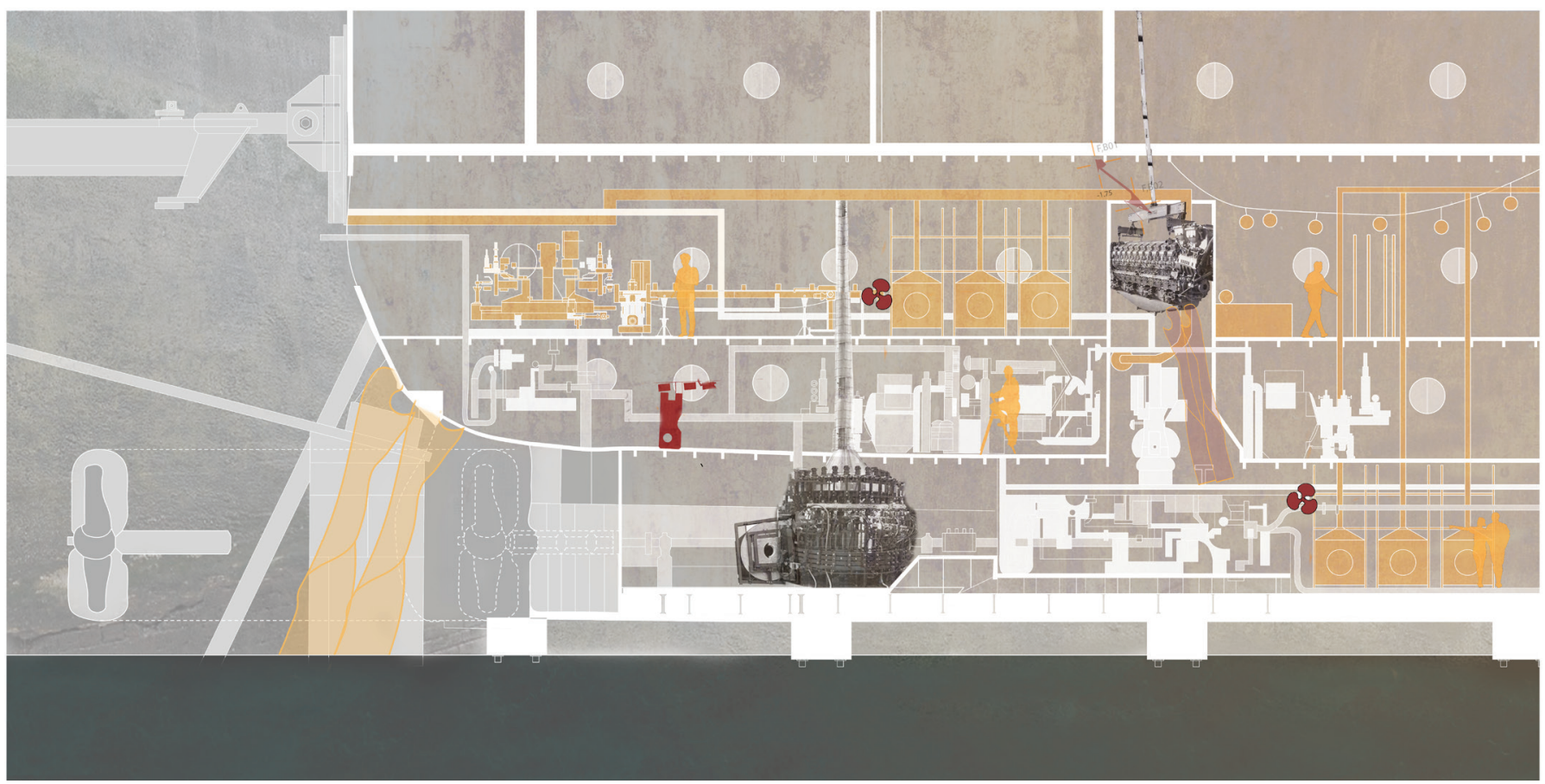

Figure 36: Glassblowing in the Hull

As the ships mechanical systems are removed glass workshops open at the lower decks of the ship. Colourful glass hangs around the workshop as the crackling of the melting of glass is heard throughout the hull. 


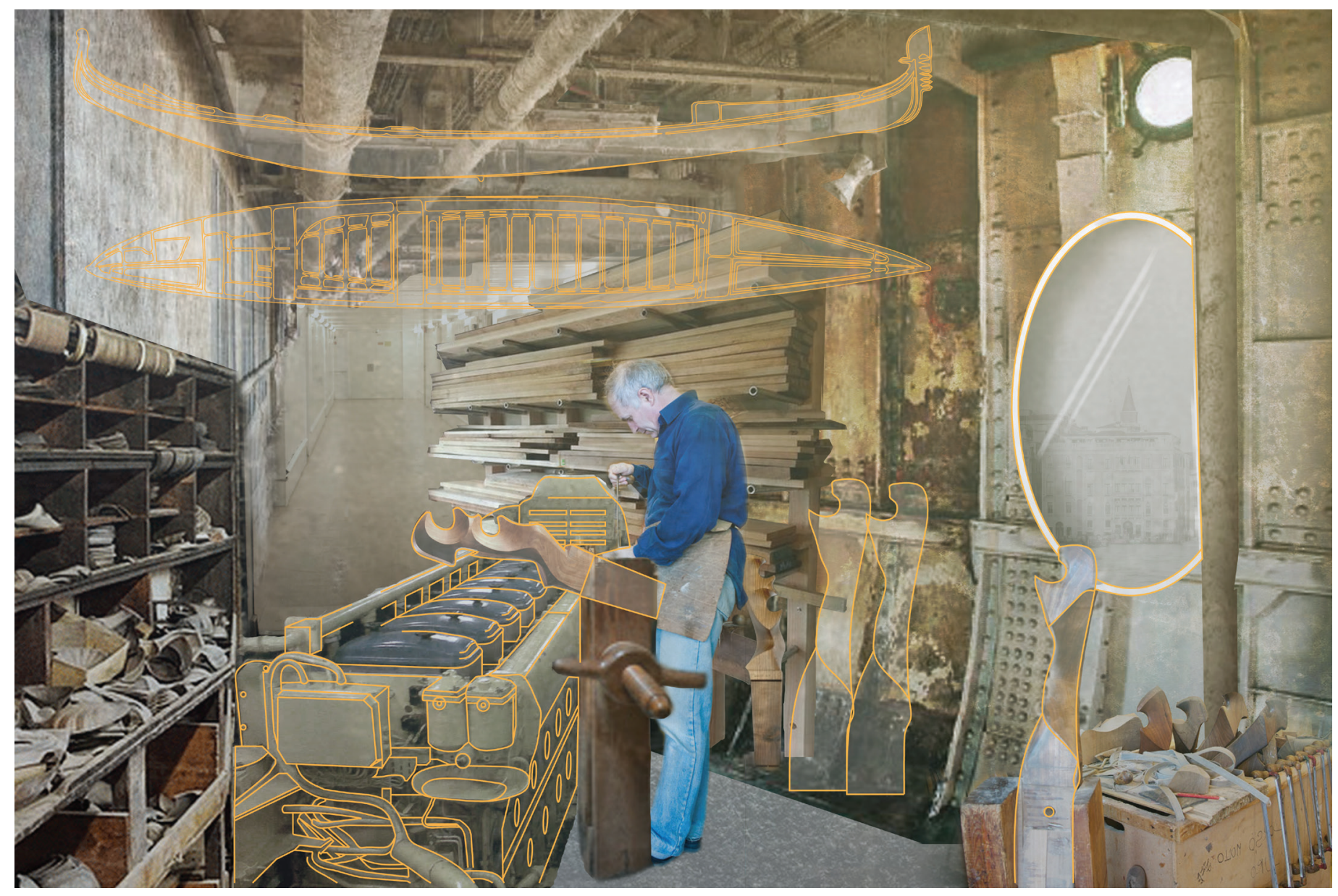

Figure 37: Gondola Workshop

The lower decks of the Academia ship, the forcola (stern) of the gondolas are shaped among the machines of the ship. 


\section{7 +: An Archeology of the Future}

The Venetians spot the tourist city, who's numbers have dropped in the introduction of a city tax. Only those who can afford it are shown the city of the tourist; galleries, basilicas and piazzas. The map of the tourist city is restricted as Venice is in the liminal period.

Constructions slows as the walls of the canal are repaired and the foundation of buildings recovered with sand. The steel cofferdams are removed from the canals. Water rushes into the Grand Canal from the docks, refilling the empty waterways, sweeping through the overgrown landscape. The piers remain as the established streets for vaporetto stops, shops and markets. The narrative of the temporal Venice concludes as the city becomes stabilized. The Venetians who choose to re-enter Venice slowly move back into their own neighbourhood. They enter a new structure of Venice, a city stabilized and repaired from previous environmental, social and economic conditions. The infrastructure from the preparation of the ship is reused, as tower cranes become reassembled as observation towers throughout the city. In this stabilization, the machines begin their departure. 
What is left is an archaeological map of Venetian ships. (Figure 38) The ships each have their final narratives, their own departure. The vessels that have become permanent housing for the Venetians in San Polo remain, along with their industries and markets. They become a part of the new city, a mixture of local and tourist. A ship breaking industry opens on the edge of the island of San Michele, a cemetery for the cruise ships of the city. (Figure 39) They are welded apart, each section of metal taken and lifted back into the city streets. (Figure 40) The remains can be seen scattered across the coordinates of Venice; a pavilion of a dismembered hull in the piazza of Campo San Polo, a propeller spinning in a playground park, a porthole in a new facade and cabins morphed into a residential complex. Vessel remains are sunk into the lagoon an ecological landscape of an archipelago of ships. The remaining ships depart the city in the same way they entered, returning to the sea. (Figure 41) 


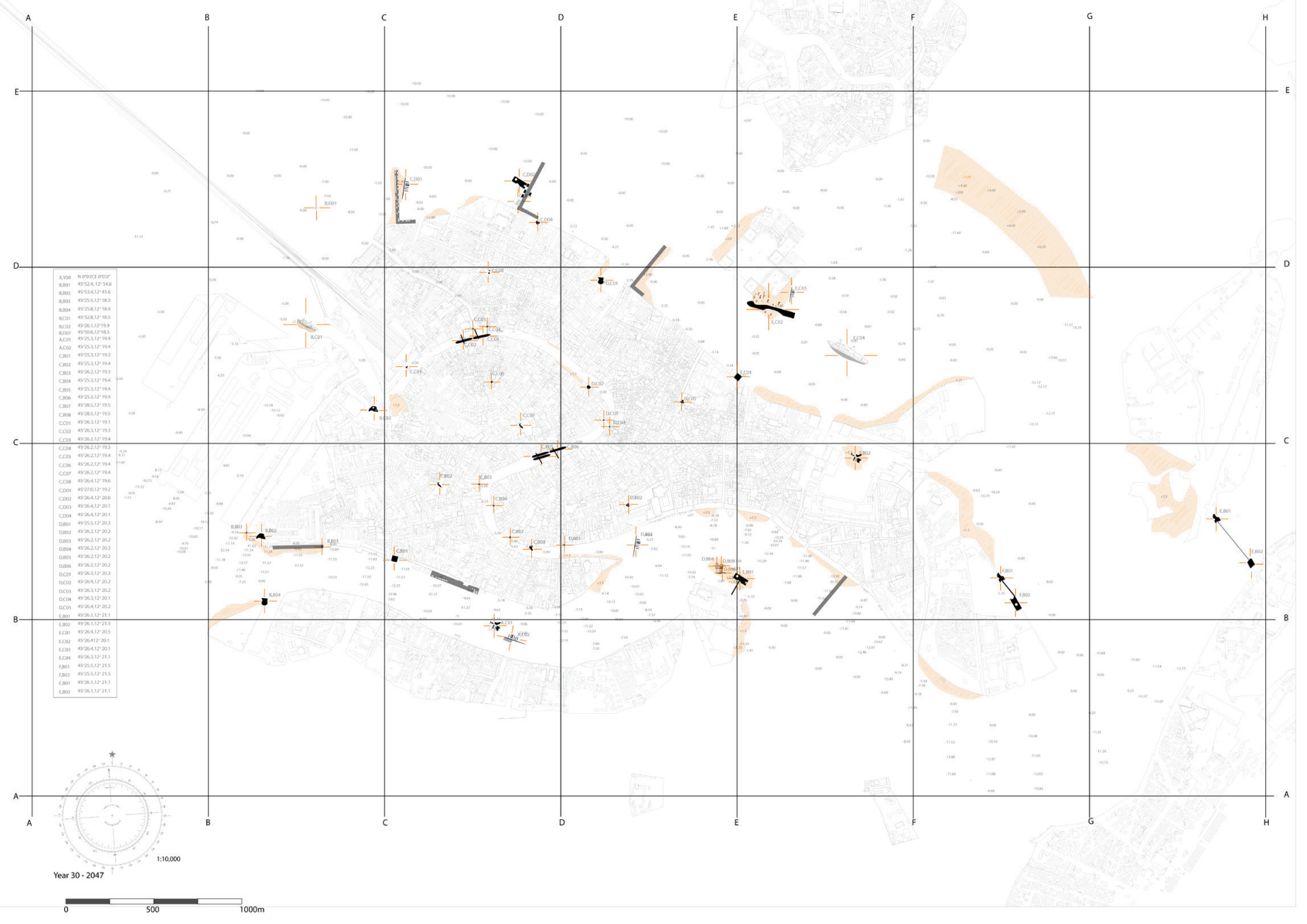

Figure 38: Archaeological Map

Each ships has its own narrative as the remains of the artifacts have their own coordinates of longitude and latitude spread across the landscape of Venice. 


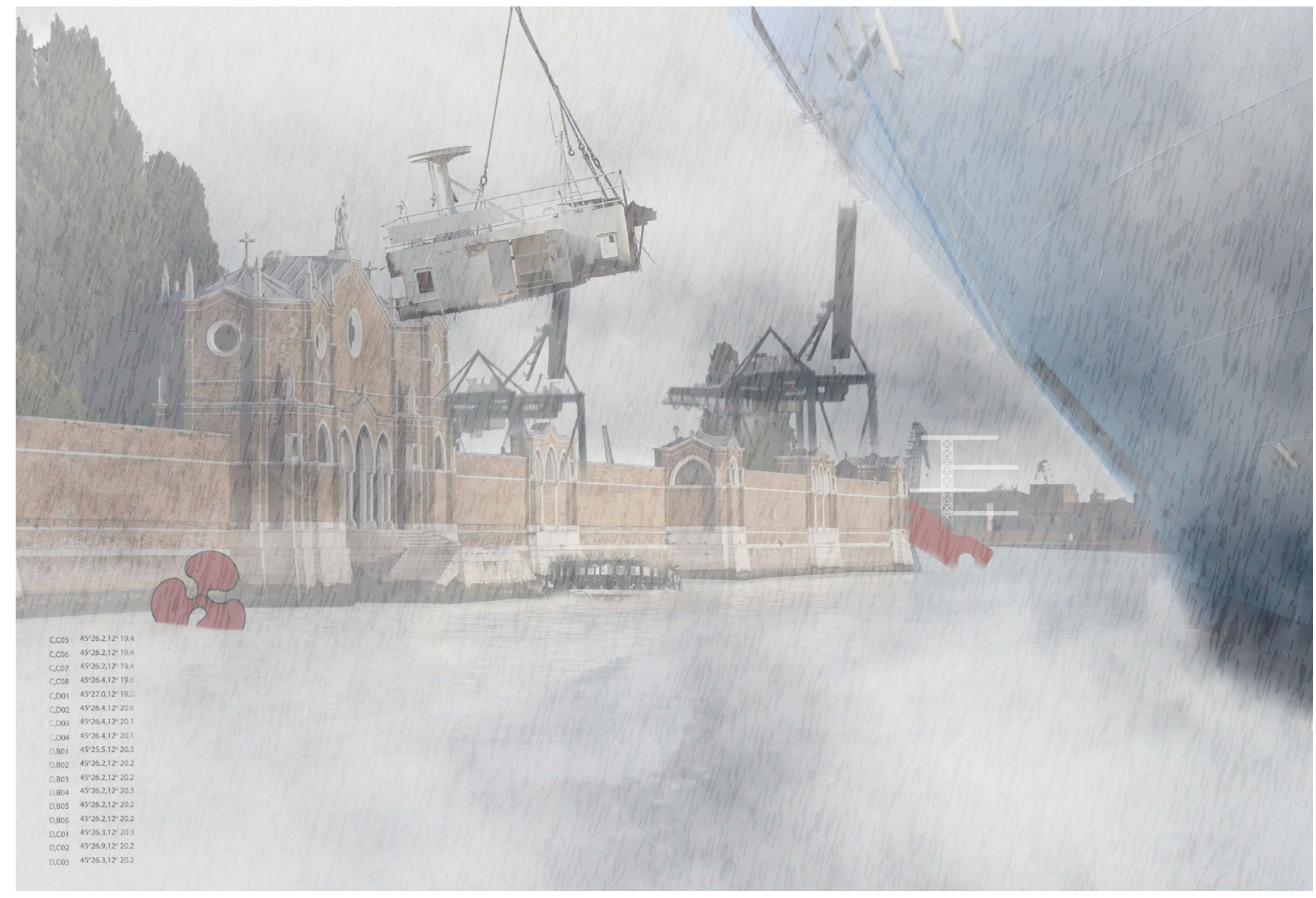

Figure 39: San Michele Cemetery

A ship breaking industry opens at the cemetery island of San Michele where the ship is dismantled the pieces placed into the streets of Venice. 


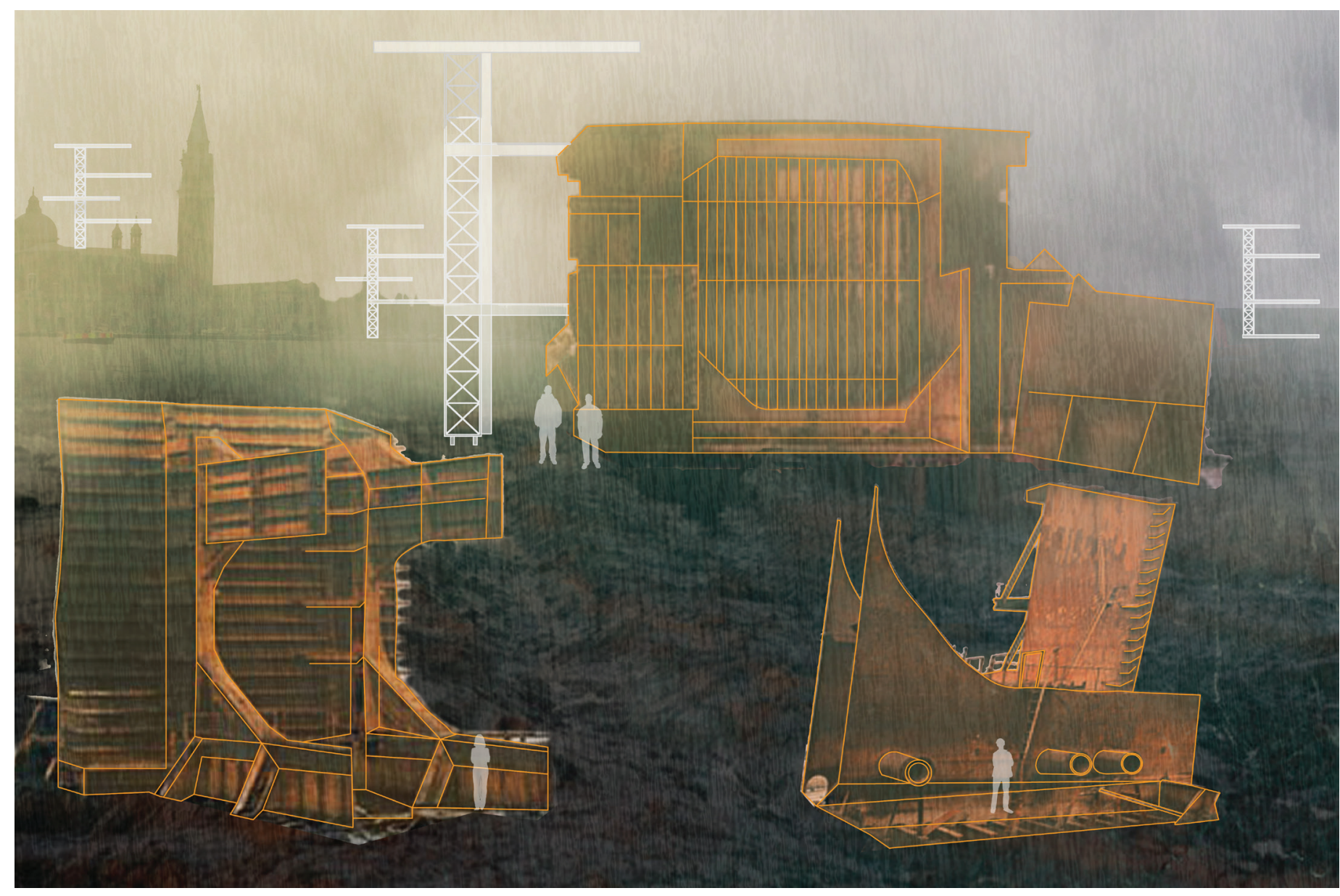

Figure 40: Ship Breaking

The remains can seen scattered across the landscape of Venice. Towers of dismantled cranes loom in the distance between the buildings. 


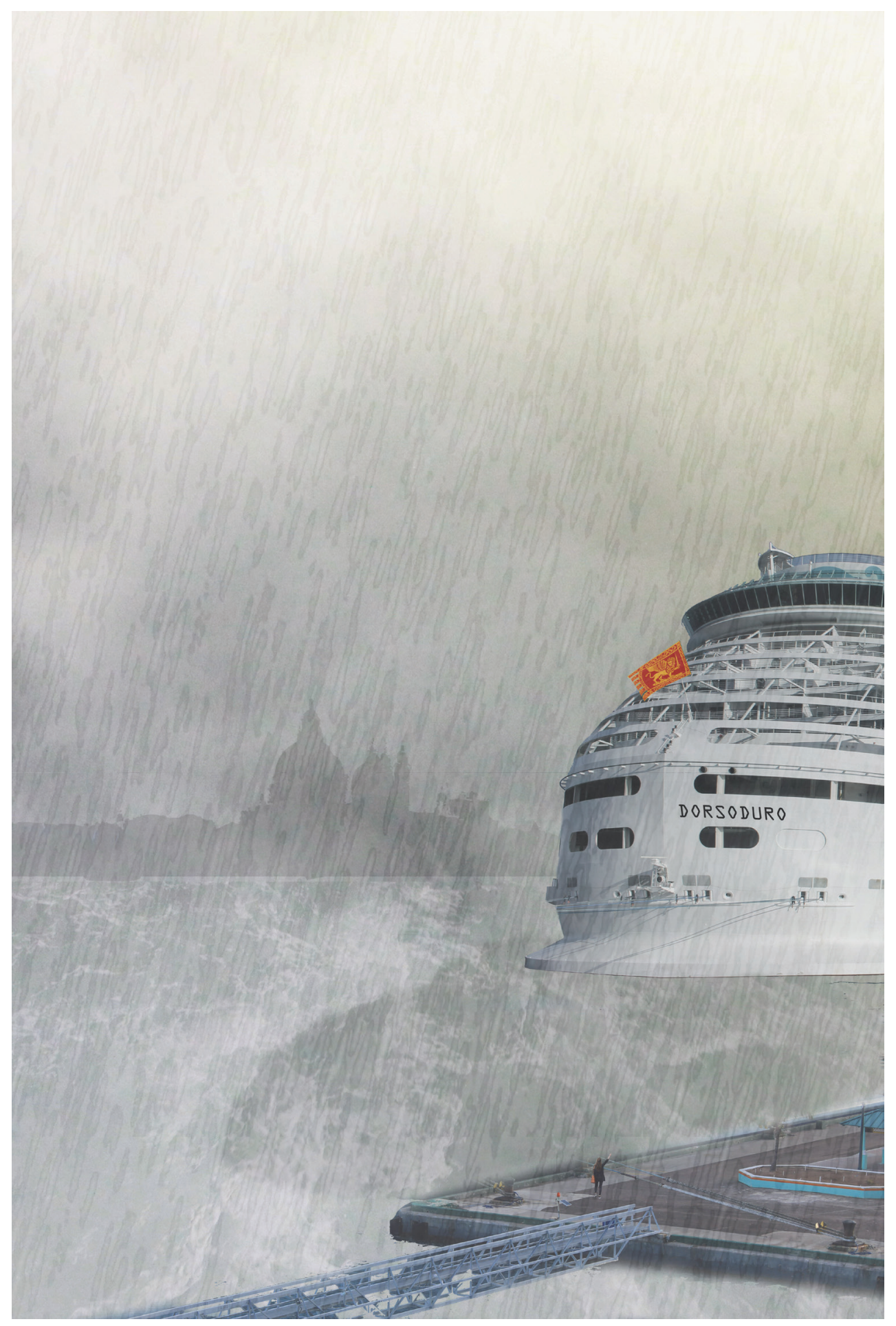

Figure 41: Disembarkation of Ships

Some ships return back from where they originated from as their lines are unsecured from the mooring bollards and the engines restart propelling the ship past the lagoon into the sea. 


\section{Postscript}

The six stories of liminal crossings, during this thirty years, opens to a post Venice that is unknown. There is an infinite number of possible future narratives as the ships, the local people and the tourists depart this temporality and enter a future Venetian time and space. With the re-stabilization of the city, and the dismantling of the ships, the post-liminal time is found within the framework of another narrative. This liminal landscape of ships provides a future structure of changing activities in the city. ${ }^{55}$ Post- Venice can only be speculated as a new fantasy within the Venetian city of tourists and locals. As liminal time provides a framework to a suspended period of Venetian history, the postscript continues past this chapter into a new structure. The following provides two brief speculations on the future, the next 30 years for the cities of Venice. 
From the first departure of the local Venetians onto the ships, one speculation of this future is that the local city has its final exodus - leaving behind the past structure of Venice. The city becomes an artifact, a new tourism for the foreigners within the remains of the ships. These remains are a reminder of the past Venice - a Venice of its local people. The remaining ships along the Grand Canal are the final locations of the original local city. It is a place of refuge for the few hundreds of Venetians that continue to reside in their city. Outside these forms of infrastructure, Venice's identity is a city of the tourist as they occupy the stabilized streets and building, becoming the new "locals" of that city. A new network of suspend connections link the city of the locals within the ships to the towers of Venice. (Figure 42) The spectacles of the city continue to bring in the tourists; water flooding Piazza San Marco, new museums opening along the Grand Canal and previous Venetian residences now all temporary secondary homes for the new "locals". Venice now inhabited by the new locals, who were once tourists, is a new constructed landscape among the memories of the ships.

The liminal crossings can open to an alternative city where its economic and infrastructural success provides a narrative of a city without the tourists. Venice becomes a city only for the locals within the repaired streets and buildings. The remains of the ship add to the stabilization of the city and develop to a new identity of the Venetians. They enter a period of Venetian history tied back to the ships, continuing the narratives that were established in liminal time. 

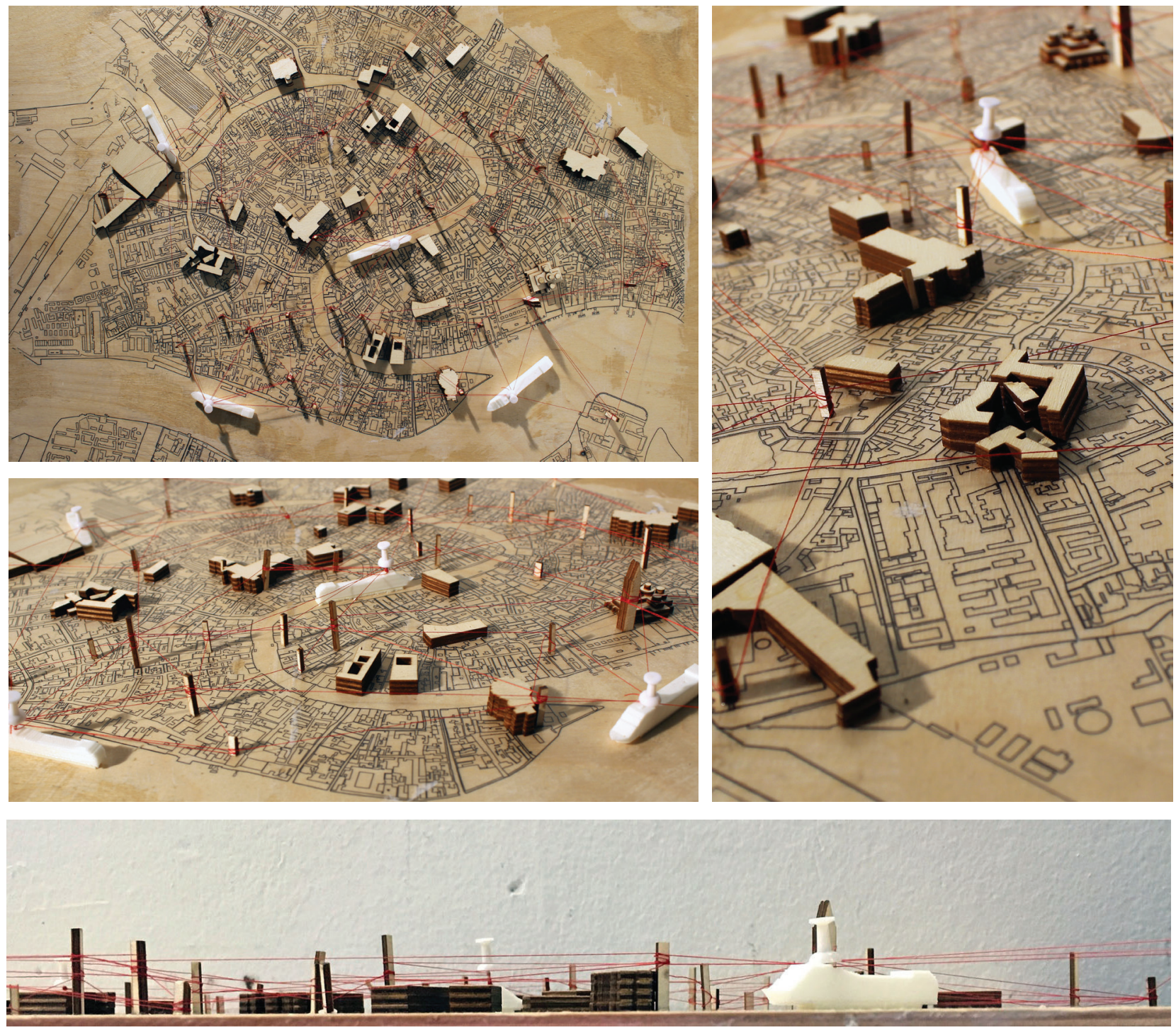

Figure 42 : Connecting Venice

The two cities are connected, ship and tower as a way to establish a new network of passageways. 
The realities of the future of the city can only be identified when the current Venice enters this liminal time. What is known is the series of liminal speculative drawings of the cruise ships within the landscape, a set of moments before a new Venice begins (Figure 43). It is a strategic organization for the accommodation of a future Venice, the ships became an instrument in the third city, allowing for the anticipation of alternative conditions to develop over time. ${ }^{56}$ The timeline of this suspended period of cityscape and landscape - ecological, social and economic systems - brings a future that is beyond what has been speculated, it may enter another series of narratives, another set of liminal crossings. 


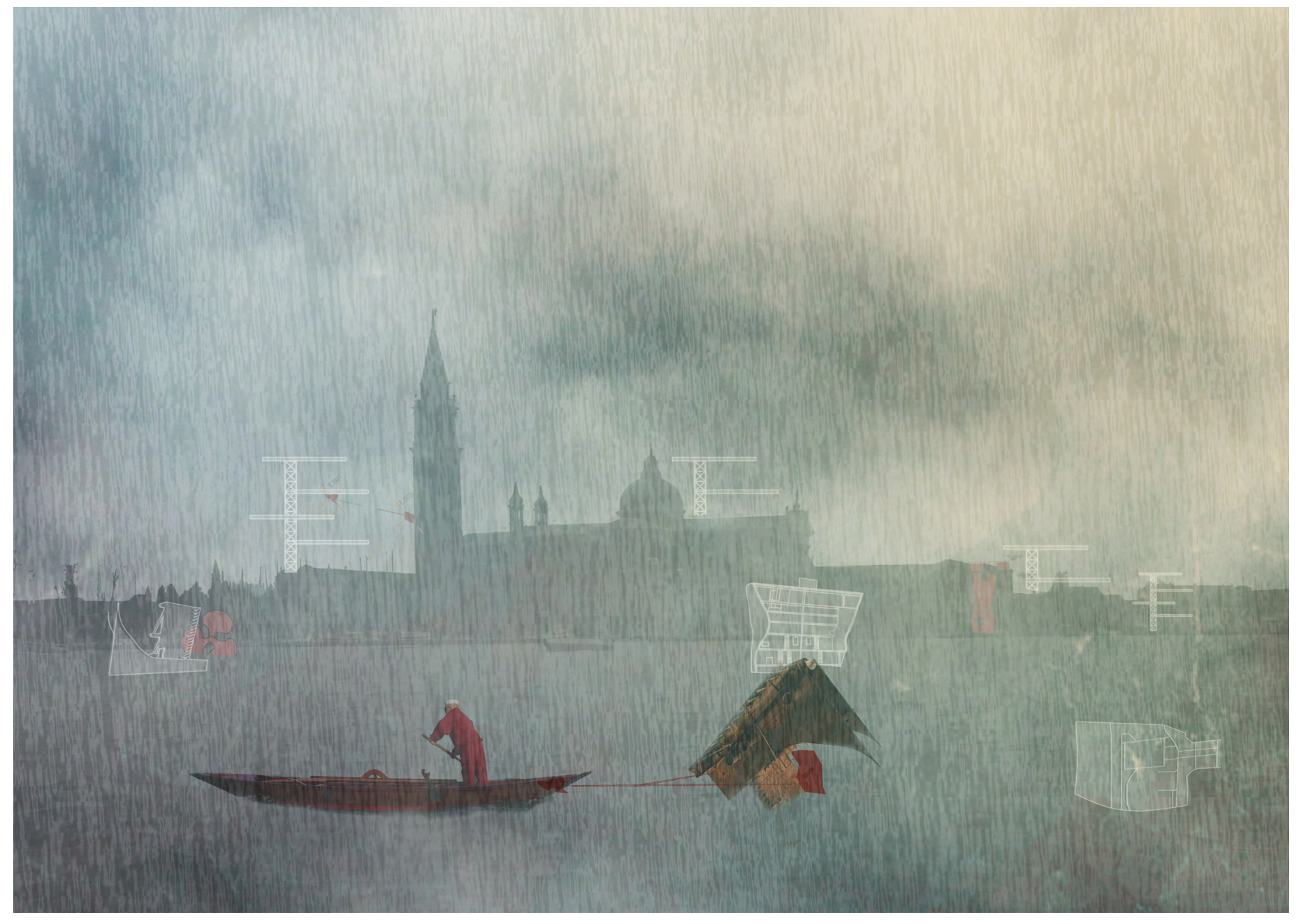

Figure 43: Post- Venice

The future Venice is a narrative of infinite possibilities as the remains of the ships and

infrastructure are set within a new structure of Venice. 


\section{Endnotes}

Part I: Liminal Space

${ }^{1}$ China Miéville, The City and The City (London: Pan Books, 2010),368.

2 The term "third city" first identified by Edward Soja in the book Thirdspace. It is further discussed, identified and understood in the chapter Liminal Space, Liminal Time, see note 34.

Edward W. Soja, Thirdspace: Journeys to Los Angeles and Other Real-and-Imagined Places (Cambridge:MA: Blackwell Publishers, 1996).

3. The narrative of the landscape of the local city as described by the Donna Leon, the contrast between the "sleepy city" of the low season, and the crowding of the city during the summer months. Donna Leon, Death at La Fenice (New York:Harper Collins,1992) 4.

${ }^{4}$ Franco Mancuso, "The Origins of the Sestieri," Venice and its lagoons, 2009, accessed February 30,2017,http://www.venicethefuture.com/schede/uk/034/?aliusid=034.

${ }^{5}$ Ibid.

6 Nick Squires, "Giant Cruise Ships 'crushing the life out of Venice,'” The Telegraph, October 22, 2015, accessed November 10 2017, http://www.telegraph.co.uk/news/worldnews/europe/ italy/11947657/Giant-cruise-ships-crushing-the-life-out-of-Venice.html.

${ }^{7}$ Ibid.

${ }^{8}$ Venice historically had a collection of guilds which combined groups of artists that had their own political and government system. Through the $19^{\text {th }}$ century the guilds abandoned their smaller businesses into the mainland as the introduction of new industrial technologies shifted the industry into mass production mills. Today the economy has shifted once again towards mass tourism.

Franco Mancuso, "Venice, An Industrial City," Venice and its lagoons, accessed February 23, 2017,http://www.venicethefuture.com.

${ }^{9}$ Peter Ackroyd, Venice: Pure City (New York: Random House Inc., 2009),42.

10 The statistic dates from 2014, taken from Giuseppe Tattara- Quantifying Cruising. Salvatore Settis, If Venice Dies, trans. Andre Naffus-Sahely (New York:New Vessel Press, 2016),10.

${ }^{11}$ Kristen Brann et al.,"25 Years of Venice Knowledge Online”, WPI Interactive Qualifying Project. (Bachelor of Science diss., Worcester Polytechnical Institute, 2013).

${ }^{12}$ Garry Marvin and Charles ,R. Davis, Venice, the Tourist Maze: a cultural critique of the world's most tourist city (California: University of California Press, 2004),120.

13 John Hooper, "Population Decline Set to Turn Venice into Italy's Disneyland," The Guardian, August 26, 2006, accessed December 10,2017, https://www.theguardian.com/world/2006/ aug/26/italy.travelnews.

${ }^{14}$ Ackroyd, Venice: Pure City,4. 
${ }^{15}$ Ibid.

${ }^{16}$ Suemedha Sood, "Keeping Venice from Sinking," BBC Travel, February 25, 2011, accessed December 12, 2017, http://www.bbc.com/travel/story/20110225-travelwise-keeping-venice-from-sinking.

17 GPS and space radar have been used to identify the rate in which the city is sinking. The data was tracked for 10 years starting in 2000. Research from the University of California are identified that the city is tilting eastward $1 \mathrm{~mm}$ yearly in addition to its sinking and flooding. Tanya Lewis, "Venice Menace: Famed City Is Sinking \& Tilting," Live Science, March 21, 2012, accessed December 15, 2016, http://www.livescience.com.

18 Ibid.

${ }^{19}$ The origins of Venice began in the fifth century during the collapse of the Roman Empire. As the barbarians were moving across Europe taking over colonies, the Roman colonies on mainland Italy escaped to the marshy swamp lands of Venice.

Garry Wills, Venice: Lion City, (New York: Simon \& Schuster,200) ,5

${ }^{20}$ Ackroyd, Venice: Pure City'24.

${ }^{21}$ Ibid.,209.

${ }^{22}$ Giulia Foscari, Elements of Venice, comp. Rem Koolhaas (Zürich: Lars Müller Publishers, 2014),598.

${ }^{23}$ Grant Bradley, "Making Megaships - How the Biggest Cruise Ships Are Built ," Herald News, September 13, 2014, accessed December 5, 2016, http://www.nzherald.co.nz/business/news/ article.cfm?c_id=3\&objectid=11323488.

24 Passageway: Interior corridors of the ship

All Definitions taken from : C.G Daley, Ship Terms and Definitions, Memorial University, accessed February 10, 2017, http://www.engr.mun.ca/ cdaley/5003/ship_terms.pdf.

25 Porthole: Circular opening in the ship's side- the window.

${ }^{26}$ Hull: The body of the ship, including the framing, decks and bulkheads.

27 The "day" tourist of the cruise ship, about 1.5 million, generates about 270 million of profit for the city but also cause 320 million in damages.

Settis, If Venice Dies,139.

${ }^{28}$ The top five most frequent cruise liners that enter the city from May to September include: FTI Cruises, Viking Ocean Cruises, Royal Caribbean International, MSC and Costa.

Venezia Terminal Passeggeri. Ship Schedule 2016. 
${ }^{29}$ Gavin Haines, "Tempers flare in Venice as angry protesters block cruise ships," The Telegraph, September 26, 2016, accessed January 3, 2017, http://www.telegraph.co.uk/travel/news/ tempers-flare-in-venice-as-angry-protesters-block-cruise-ships/.

${ }^{30} \mathrm{lbid}$.

${ }^{31}$ Victor Turner, anthropologist, use liminality to describe the subject that is neither located in the departed stage nor arrived to a new form and it reliant on the presence on both states. It is designated to those to states that is no longer classified and not yet classified. The term is understood in the context of the ships as being the means to hold the Venetians during the liminal time. It is an architectural understanding of a space that is not defined as apart of the two cities of Venice and yet present in both.

Victor Turner, "Betwixt and Between: The Liminal Period in Rites de Passage" The Forest of Symbols Aspects of Ndembu Ritual (New York: Cornell University Press, 1967),46.

32 The definition of Liminal (n.) from the Latin word "limen", occupying a position on both sides of a boundary or threshold, Oxford Dictionary

Oxford Dictionaries, s.v. "Liminal," accessed April 2017, http://www.oxforddictionaries.com.

${ }^{33}$ Liminality from the folklorist, Arnold Van Gennep, Rite of Passage determine the term to accompany the passage between the change of place, state, social position, religious calling and age in culture. It is the moment between less stable phase of social process, where the individual is removed from their social structure and power.

Victor Turner, The Forest of Symbols Aspects of Ndembu Ritual,47.

${ }^{34} \mathrm{Edward}$ Soja uses the concept from Henri Lefebvre, an-other, a third "moment" that is more then the just a combination of its binaries. It is a temporal sequence that provides "other-than" choice that is a tentative reconstruction of an moment. It is an alternative condition to its two binaries by being both similar and yet strikingly different. In terms of space and time it is a chain of disruptions that allow for an openness in terms of non-permanent construction. In the context of Venice, this term is further understood as an alternative third time of timeline of temporal moments to occur. The ships, which are currently part of the city of tourist are turned into a sequence of events that are apart of the two cities and yet spatially and programmatically used for the locals.

Edward W Soja, Thirdspace: Journeys to Los Angeles and Other Real-and-Imagined Places (Cambridge, MA: Blackwell Publishers, 1996),60-61.

${ }^{35}$ Liminal time referenced Gennep's ideas on this theory is defined as a phase in essence and function that is transitional, intermediate and conditional between an "hardened" (established) and transformed structure. Within Venice, it is a set phase for the transformation of the city. Irma Ratiani , "Liminality and the Liminal Theory of Conceptualizing Time and Space in 20th century Eschatological Anti-utopia. , trans. Ariane Chanturia, Theory of Liminality,2. 
PART II: Journal from Aboard

${ }^{36}$ Gangway: the bridge connected from port to ship. During the cruise, there were two main types of gangways used, one was a enclosed bridge at deck 5 and the other on deck 2 a small retractable bridge.

${ }^{37}$ Mooring bollards: short vertical post for securing lines on a dock

${ }^{38}$ During the all access tour the motion of the ship was explained as the propellers, in which two out of the three can rotate 180 degrees allowing the ship to disembark without the traditional tug boats that have been previously used on older ships to maneuver out of the dock.

${ }^{39}$ The room was measured to be about $25 \mathrm{sqm}$. The size or rooms varies on the number of passengers. With two beds swinging from the ceiling in an room with four individuals. Bellow deck six cabins have portholes that are inoperable, from deck six to 10 balconies are available.

40 Muster Station: meeting place on ship that is referred to in an emergency where you would locate lifeboats. Each sea pass is identified with a letter and number. On the Navigator of the Seas the muster station was B12 on deck 4.

${ }^{41}$ Within the section of the ship there is very little vertical connection, aside from the interior promenade, and elevator shafts there was very limited double story spaces. Through my observations there was no natural light in lower decks of the public space.

42 Cruise ship stabilizers, wing like flaps that open in rough water, were deployed during the cruise as the ship encountered rough waters on night three crossing the Atlantic Ocean.

43 I-95 Refers to the highway sign that is used by the crew of the Navigator of the seas as a reference to the crews' longest passageway of the ship. During the access tour, it was the main passage of access to all the back of house program.

${ }^{44}$ Buoyant: rubber inflated tube that are attached to the end of the piers, preventing damage to the vessel when docking at a pier. During the cruise at each port the form of the buoyant barrier was different, some where suspended pier and the ship while others were a mechanism that was bolted to the pier. 
PART III: Liminal Time

${ }^{45}$ The narratives design a constructed landscape within a framed time and space. As a precedent to strategy in the framework liminal time is through Frederick Law Olmsted. In his design of Boston landscape of "wilderness", he invented methods of practice for solutions of social and environmental problems in the construction of an urban wetland system. In the same way, the six stories open to an series of methods for the liminal Venice in its infrastructural and architectural design.

Anne W. Spirn, "Constructing Nature: The Legacy of Frederick Law Olmsted", in Uncommon Ground. Ed. William Cronon et al. (New York: W.W. Norton \& Company ,Inc., 1996), 104.

${ }^{46}$ Bathymetry charts of the Lagoon, especially on the northern area of the city indicated that the depth of the lagoon is shallow, between 1.48 to 4 meters. A minimum of 9 meters is required for the cruise ship draught (vertical length from the waterline to the bottom of the hull) to enter this area. In the grand canal, with depths from 2 to 6 meters minor dredging will need to occur to be able to allow the 5 -meter draught of the cruise ship to enter.

${ }^{47}$ The machine has a maximum bucket load of $900 \mathrm{~L}$ of sand and reaches a depth of 31.50 meters. "Adriatico," DEME Group, accessed March 10, 2017, http://www.deme-group.com/technology/ adriatico.

${ }^{48}$ The passenger capacity of the ships is divided between two types. The smaller vessels hold 300 passengers and the larger vessels hold 2500 . The refence of the ship sizes are taken from typical cruise ships that currently enter the port terminal. The precedent ships include the FTI Berlin and the Royal Caribbean Splendor of the Seas.

${ }^{49}$ The process of stabilization of Venice steams from the current methods of architectural restoration precedent of Santa Maria dei Miracoli exterior and interior process of removing salt, rebuilding interior windows and repairing stone facade.

Randolph H Guthrie, "Santa Maria dei Miracoli: A Miracle of Restoration," Save Venice, accessed March 10, 2017, https://savevenice.org.

${ }^{50}$ The Grand Canal becomes a graving dock, where the canal is divided into a caisson(unit) for the ships.

David J. House, Dry Docking and Shipboard Maintenance: a Guide for Industry, 2nd ed. (London: Routledge Taylor et Francis Group, 2016).

${ }^{51}$ The canal dredge to a level of $-180 \mathrm{~cm}$ from the center of the canal. Common practice developed by the restoration foundation Insula of Venice in the draining of canals.

Insula, Venice : Preservation and urban Maintenance, accessed March 2017, http://www.insula.it 
52 The thicker outer walls of the houses are repaired with an inward flex placement of brick to strengthen the overall structure. Giulia Foscari, Elements of Venice,608.

${ }^{53}$ The process of restoring the Venetian canals are referenced from the current methods that are used in the repairing of the walls by Insula. The walls are in constant erosion from the water that filters though the masonry brick, shifting the mud inside. The stabilization of the structures will continue to used the traditional methods for partial reconstructions with a layer of protective plaster to the future water level. Ibid.609

${ }^{54}$ The process of glass melting follows the traditions that are practiced within existing studios, the machines of glass blowing are placed within the hull of the ship.

"The Process of Blowing Glass," Sacramento Art Glass, accessed March 29, 2017, http://www. sacramentoartglass.com/the-process-of-blowing-glass.html.

${ }^{55}$ Landscape refers to an condition for an active surface that accommodates the city, allowing for fixed and changing conditions over time. In the context of Venice, the remains of the ships allows for a new landscape that can adapt to the future Venetian demands. Alex Wall, "Programming the Urban Surface", Recovering Landscape: Essays in contemporary Landscape Theory, Ed. Jame Corner (New York:Princeton Architectural Press, 1999),234.

${ }^{56}$ The thesis developed a framework for a flexible future in which the proposed ships and their infrastructure can accommodate the cit. Its precedent in strategy is similar to the precedent of Parc De La Villette, where the Office for Metropolitan Architecture (OMA) developed a framework instead of a defined design in the anticipation of alternative futures for the park.

Alex Wall, "Programming the Urban Surface,"238. 


\section{Bibliography}

Ackroyd, Peter. Venice: Pure City. New York: Random House Inc., 2009.

“Adriatico." DEME Group. accessed March 10, 2017. http://www.deme-group. com/technology/adriatico.

Bradley, Grant. "Making Megaships - How the Biggest Cruise Ships Are Built ", NZ Herald News. September 13, 2014. accessed January 2, 2017. http://www. nzherald.co.nz/business/news/article.cfm?c_id=3\&objectid=11323488.

Brann Kristen,Giola Gregory, Kirbby Dylan and Rictmyer Will."25 Years of Venice Knowledge Online", WPI Interactive Qualifying Project. Bachelor of Science diss., Worcester Polytechnical Institute, 2013.

Daley, C.G. Ship Terms and Definitions. Memorial University. accessed February 10, 2017.http://www.engr.mun.ca/ cdaley/5003/ship_terms.pdf.

Foscari, Giulia. Elements of Venice. Forward by Rem Koolhaas. Zürich: Lars Müller Publishers, 2014.

Ganz, Barbara. "Venice Forecasts Decline of Cruise Passengers Again in 2016 as Ship Ban Drags on."Italy24. May 21, 2016. accessed December 15, 2016. http://www.italy24.ilsole24ore.com.

Guthrie, Randolph H. "Santa Maria dei Miracoli: A Miracle of Restoration." Save Venice.1995. accessed March 10, 2017. https://savevenice.org.

Haines, Gavin. "Tempers flare in Venice as angry protesters block cruise ships." The Telegraph. September 26, 2016. accessed January 3, 2017. http://www. telegraph.co.uk/travel/news/tempers-flare-in-venice-as-angry-protestersblock-cruise-ships/.

Hooper, John. "Population Decline Set to Turn Venice into Italy's Disneyland." The Guardian ,August 26, 2006. accessed December 10,2017. https://www. theguardian.com/world/2006/aug/26/italy.travelnews.

House, David J. Dry Docking and Shipboard Maintenance: A Guide for Industry. 2nd ed. London: Routledge Taylor et Francis Group, 2016.

Insula. Venice : Preservation and urban Maintenance. Venice: Insula. http://www. insula.it/images/pdf/resource/brochurepdf/brochure-manutenzione-eng. pdf. 
Leon,Donna. Death at La Fenice. New York:Harper Collins,1992.

Lewis, Tanya. "Venice Menace: Famed City Is Sinking \& Tilting." Live Science. March 21, 2012. accessed December 15, 2016. http://www.livescience. com/19195-venice-sinking-slowly.html.

Mancuso,Franco. "Venice, An Industrial City," Venice and its lagoons, January 2016 , accessed February 23, 2017. http://www.venicethefuture.com/ schede/uk/331 ?aliusid=331.

Mancuso, Franco. "The Origins of the Sestieri," Venice and its lagoons, 2009, accessed February 30,2017.http://www.venicethefuture.com/schede/ uk/034/?aliusid=034.

Marvin, Garry, and Charles ,R. Davis. Venice, the Tourist Maze: A Cultural Critique of the World's Most Tourist City. California: University of California Press, 2004.

Miéville, China. The City and the City. London: Pan Books, 2010.

Ratiani , Irma. Liminality and the Liminal Theory of Conceptualizing Time and Space in 20th century Eschatological Anti-utopia. Translated by Ariane Chanturia.

Settis, Salvatore. If Venice Dies. Translated by Andre Nnaffus-Sahely. New York:New Vessel Press, 2016.

Soja, Edward W. Thirdspace: Journeys to Los Angeles and Other Real-and-Imagined Places. Cambridge, MA: Blackwell Publishers, 1996.

Sood, Suemedha. "Keeping Venice from Sinking." BBC Travel. February 25, 2011. accessed December 12,2017.http://www.bbc.com/travel/story/20110225-travelwise-keeping-venice-from-sinking.

Spirn , Anne W. "Constructing Nature: The Legacy of Frederick Law Olmsted". Uncommon Ground, edited by William Cronon,Slater Candace,Merchant Carolyn, 91-113. New York: W.W. Norton \& Company Inc,1996.

Squires, Nick. "Giant Cruise Ships crushing the life out of Venice." The Telegraph, October 22, 2015. accessed November 10 2017, http://www.telegraph. co.uk/news/worldnews/europe/italy/11947657/Giant-cruise-ships-crushing-the-life-out-of-Venice.html. 
Turner, Victor. "Betwixt and Between: The Liminal Period in Rites de Passage" The Forest of Symbols: Aspects of Ndembu Ritual. Ithaca, NY: Cornell University Press,1967.

"The Process of Blowing Glass." Sacramento Art Glass. Accessed March 29, 2017. http://www.sacramentoartglass.com/the-process-of-blowing-glass.html.

Venezia Terminal Passeggeri. Ship Schedule 2016. accessed November 3020116. http://www.vtp.it/en/ship-schedule/.

Wall, Alex. "Programming the Urban Surface", Recovering Landscape: Essays in contemporary Landscape Theory, Ed. Jame Corner.New York:Princeton Architectural Press, 1999.

Wills, Garry. Venice: Lion City. New York: Simon \& Schuster,2001. 